UNIVERSIDAD POLITÉCNICA DE MADRID

ESCUELA TÉCNICA SUPERIOR DE INGENIERÍA DE MONTES, FORESTAL Y DEL MEDIO NATURAL
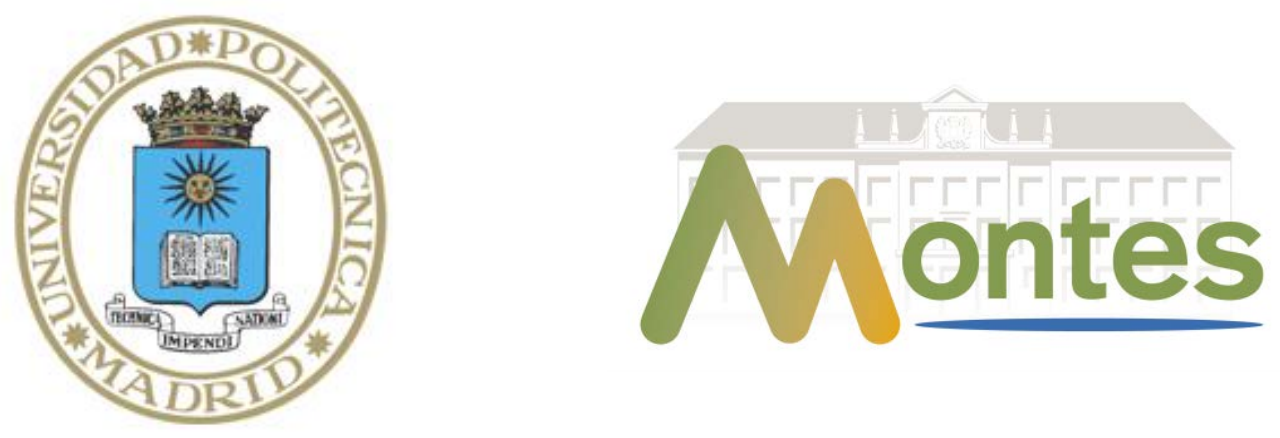

\title{
APLICACIÓN DE LA TEORÍA DE GRAFOS A LA ECOLOGÍA FLUVIAL: ANÁLISIS DE LA PÉRDIDA DE CONECTIVIDAD LONGITUDINAL EN LOS RÍOS ESPAÑOLES POR LA PRESENCIA DE PRESAS
}

TESIS DOCTORAL

Gonzalo Rincón Sanz

Licenciado en Ciencias Ambientales 

PROGRAMA DE DOCTORADO INTERUNIVERSITARIO EN ECOLOGÍA. CONSERVACIÓN Y RESTAURACIÓN DE ECOSISTEMAS

ESCUELA TÉCNICA SUPERIOR DE INGENIERÍA DE MONTES, FORESTAL Y DEL MEDIO NATURAL
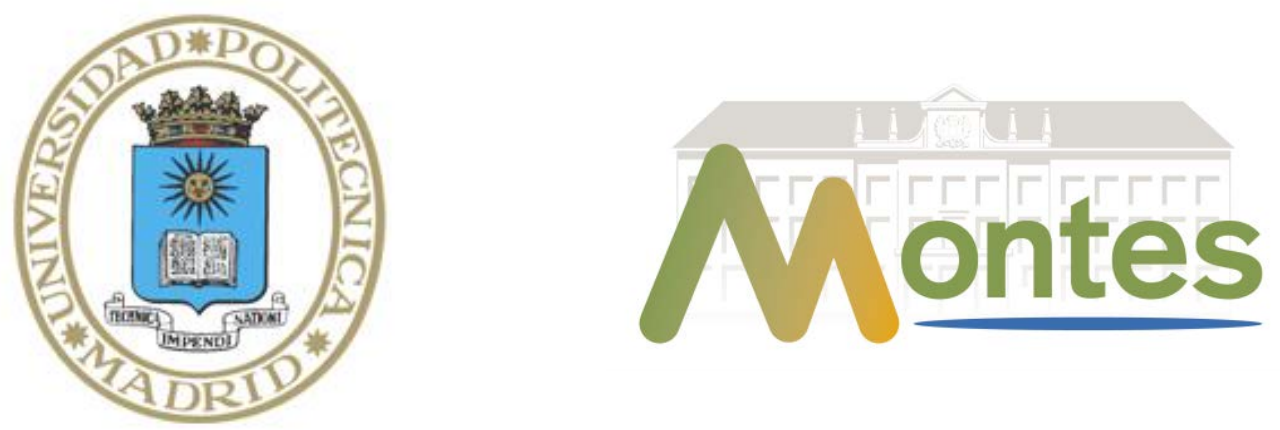

\section{APLICACIÓN DE LA TEORÍA DE GRAFOS A LA ECOLOGÍA FLUVIAL: ANÁLISIS DE LA PÉRDIDA DE CONECTIVIDAD LONGITUDINAL EN LOS RÍOS ESPAÑOLES POR LA PRESENCIA DE PRESAS}

Gonzalo Rincón Sanz

Licenciado en Ciencias Ambientales

Directores:

Joaquín Solana Gutiérrez

Doctor Ingeniero de Montes

Carlos Alonso González

Doctor Ingeniero de Montes 

PROGRAMA DE DOCTORADO INTERUNIVERSITARIO EN

ECOLOGÍA. CONSERVACIÓN Y RESTAURACIÓN DE ECOSISTEMAS

ESCUELA TÉCNICA SUPERIOR DE INGENIERÍA DE MONTES,

FORESTAL Y DEL MEDIO NATURAL
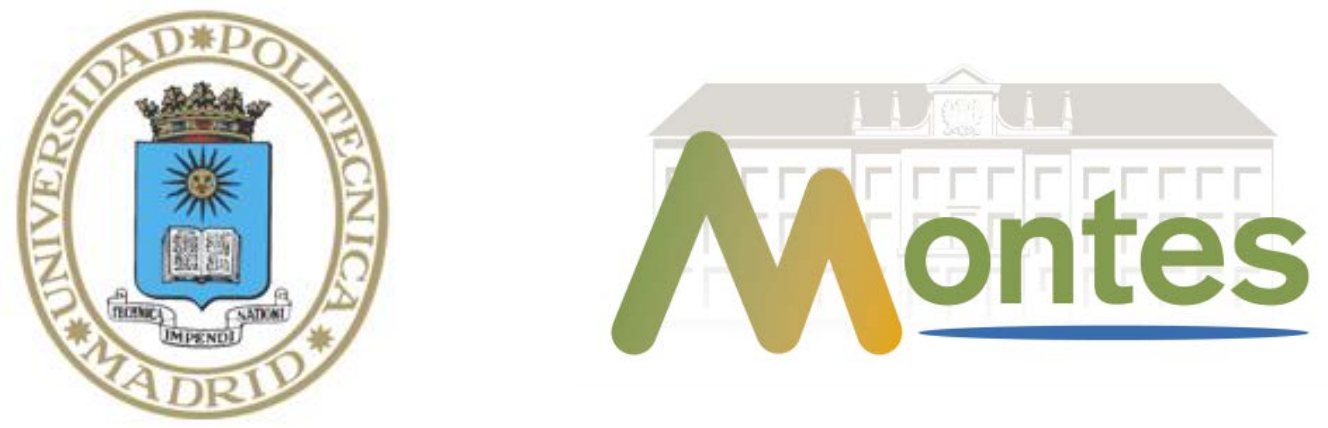

\section{APPLICATION OF GRAPH THEORY TO FLUVIAL ECOLOGY: ANALYSIS OF THE LOSS OF LONGITUDINAL CONNECTIVITY IN THE SPANISH RIVER BY THE PRESENCE OF DAMS}

Gonzalo Rincón Sanz

Licenciado en Ciencias Ambientales

Supervisors:

Joaquín Solana Gutiérrez

Doctor Ingeniero de Montes

Carlos Alonso González

Doctor Ingeniero de Montes 



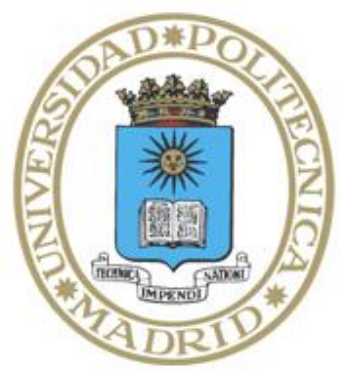

Universidad Politécnica de Madrid

Tribunal nombrado por el Magfco. y Excmo. Sr. Rector de la Universidad Politécnica de Madrid, el día... de. de $20 \ldots$

Presidente:

Vocal:

Vocal:

Vocal:

Secretario:

Suplente:

Suplente:

Realizado el acto de defensa y lectura de la Tesis el día.......de. de $20 \ldots$ en la E.T.S.I./Facultad.

EL PRESIDENTE LOS VOCALES 

A mis padres

A mi hermana

Para Alba, anar kaluva tielyanna!

"Hay que hacer el mundo lo suficientemente reconocible como para anclarnos en una realidad y lo suficientemente mágico como para transportarnos fuera de ella"

JRR Tolkien 



\section{Agradecimientos}

\section{Algo termina, algo comienza.}

Realizar una tesis sin financiación en un país que no es especialmente agradecido con la investigación puede ser una decisión no especialmente recomendable. Si me permiten un símil que creo que viene a cuento: algunos peces tienen la capacidad de superar una serie de obstáculos a lo largo del río para poder completar su ciclo de vida y desarrollarse plenamente. Si cada vez encuentra más barreras y estas a su vez son cada vez más difíciles de ser superadas, ese pez corre el riesgo de agotarse y rendirse resignándose a quedarse en un tramo de río cuyo hábitat no sea tan propicio para él. Nadie dijo que fuera fácil y es cierto que la idea de desistir y rendirme ha rondado mi cabeza en algunas ocasiones. Sin embargo, que se hayan podido superar los obstáculos y finalizar este proceso ha sido gracias a una serie de personas a las que quiero expresar mi gratitud y que merecen por derecho propio aparecer en estas líneas.

En primer lugar quiero agradecer a mis padres, Chus y Carlos, todo el tesón que han puesto para que llegara donde estoy. Sin su apoyo moral y económico, sin su cabezonería (especialmente la de mi madre que fue la que me insistió e insistió para que mandara mi currículum a varios departamentos hasta que al final encontró una oportunidad), sin su paciencia, sus consejos, sin su cariño nada de esto habría pasado. Esta tesis os la debo cien por cien a vosotros. A mi hermana Ana, por todo lo compartido durante estos años y lo que aún nos queda. A nuestro perro Rol, espero que algún día pueda disfrutar de los ríos tanto como él lo hace.

A mis directores de tesis, Carlos y Joaquín, por haberme guiado a través de este largo y en ocasiones arduo proceso. He aprendido mucho de vosotros y me habéis ayudado a madurar y a tener una visión crítica. Gracias a vosotros tengo una mochila mejor preparada para enfrentarme a retos futuros tanto en el campo de la investigación como para muchos otros ámbitos de la vida.

A toda la gente del grupo de Hidrobiología de la UPM, que tan bien me han tratado durante estos años. A Diego por haberme dado la oportunidad de empezar en este grupo y a Marta por acogerme y permitirme participar en nuevos retos.

A Vanesa por ser la mejor compañera de despacho y consejera durante buenos y malos momentos. Me has ayudado mucho a desarrollar la rigurosidad con la que debe proceder un buen investigador a la vez que me has orientado en los momentos en que 
más perdido me encontraba. Tu compañerismo ha sido fundamental en los momentos de desánimo.

A Judit que tanto peleó para que pudiera quedarme en el grupo y que me dio la oportunidad de hacer los primeros viajes de campo en los que me enseñó lo que sé sobre vegetación de ribera. Por las risas en aquellos largos viajes en el viejo Subaru buscando una emisora de radio decente. Se te sigue echando de menos por el grupo.

A Javier Gortázar "Fá", por haberme proporcionado la oportunidad de trabajar en proyectos tan variados e interesantes y que además me han ayudado económicamente a poder continuar con esta tesis. Ha sido un placer poder aprender contigo y espero que pueda seguir siendo por mucho tiempo más.

A Alejandro Gutiérrez, por sus excepcionales valores humanos y su espíritu crítico (aunque sé que esto último a veces le da algún que otro quebradero de cabeza). He tenido la gran suerte de compartir contigo discusiones, charlas y buenos momentos.

A Dani, el del espíritu inquebrantable, por todos los proyectos que aún nos quedan por realizar.

A los compañeros del laboratorio, tanto a los que aún siguen por aquí como a los que han seguido su camino en otros lugares. Me gustará dar las gracias especialmente a Chema, a Loles, a Javichín, a Bux (iese cangrejismo!), a Pablo que tuvo que emigrar a Florida para desarrollar su talento, a Demetrio que apuraba la vida a tragos como chupitos de tequila, a Efraín que se marchó demasiado pronto dejándonos un gran vacío, a Óscar que le perdí la pista, a Claudia que ahora está aprendiendo a falar galego, a Khosro que cada día es un poquito más madrileño, a María por su estancia breve pero intensa, a Jesús por su tesón y a Álex que llegó hace poco pero seguro que tiene muchas cosas que decir.

A mi familia, en especial a mi abuelo que no pudo ver la finalización de esta tesis.

A mi segunda familia, a Baro, Mario y Caco, cuya gran aventura comenzó el día que nos mudamos juntos al piso de Francos Rodríguez cumpliendo uno de nuestros sueños de adolescencia. Por todos los momentos que hemos compartido en Madrid, en Valladolid y donde nos toque en el futuro. Y a Miki, que aunque no pudo estar mucho tiempo, su recuerdo será imborrable. Estoy muy agradecido de que me hayáis elegido como amigo. 
A mis amigas y amigos, Elisa, Eva, Clara, Juncal, Irene, David (aún nos queda alguna juerga pendiente), Lucas, a los pescaítos sureños Dani y Alex, a Krisoa, Javi Blanco, y a Elisa "la socia". A los geofrikis Miguelón y Javi, por que podamos volver a reunirnos en Campillos-Sierra muchos años más. A Henar, Lau, Alba y Moni, por las noches madrileñas y la acampada libre. A Daniel Nyqvist al que espero poder ir a visitar a Suecia pronto y a Gloria Lázaro por el apoyo mutuo con la (escasa) información disponible cuando ella trabajaba en el proyecto AMBER y yo hacía el inventario de obstáculos de cada Demarcación Hidrográfica.

A las compas de La Enredadera, Nuria, Gloria, Lucía, Manuela, Rai, César, Sonia, Susana y Almudena. Que sigan sonando los ritmos de libertad.

A María y Luís, que me abrieron las puertas de su casa con generosidad y que me han acogido como a uno más.

A los compañeros de Okami (y agregados) por tan buenos ratos tanto en la arena como en el porkside. En especial a mi primo Miguel por ser la voz de la sensatez.

Mi agradecimiento a Alexandra Elbakyan, fundadora de Sci-Hub, por ayudar a eliminar las barreras en el ámbito de la ciencia y la distribución del conocimiento.

También quiero expresar mi admiración a todos los investigadores, y de entre ellos los investigadores jóvenes, que deben enfrentarse cada vez a condiciones más precarias para poder desarrollar su profesión y continuar con las cosas que les apasionan.

Finalmente, para ti, Alba, que has decidido acompañarme por este río de aguas turbulentas que es la vida. Gracias a ti la corriente es un poco menos fuerte.

Algo termina, algo comienza. Atrás se quedan muchas vivencias, recuerdos y anécdotas, momentos malos y buenos. Pero por delante quedan muchas cosas más por descubrir.

A todos vosotros, y a los que se me hayan podido olvidar, muchas gracias. 
"THERE'S no sense in going further-it's the edge of cultivation," So they said, and I believed it - broke my land and sowed my cropBuilt my barns and strung my fences in the little border station Tucked away below the foothills where the trails run out and stop.

Till a voice, as bad as Conscience, rang interminable changes On one everlasting Whisper day and night repeated-so:

"Something hidden. Go and find it. Go and look behind the Ranges"Something lost behind the Ranges. Lost and waiting for you. Go!"

Rudyar Kipling. The explorer (1898) 


\section{INDEX}

RESUMEN

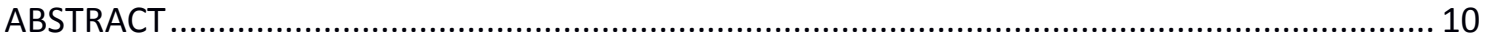

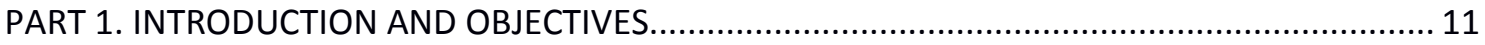

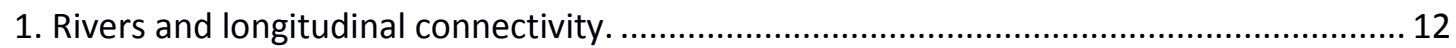

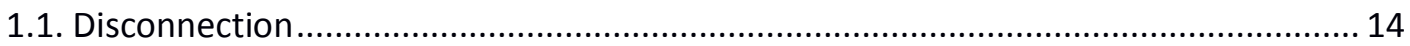

2. The application of graph theory as an opportunity to manage the fragmentation problem.

2.1. The importance of applying modelling tools in fluvial ecology.................................... 16

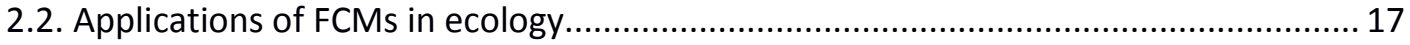

3. Improvement of the existing information on barriers ..................................................... 18

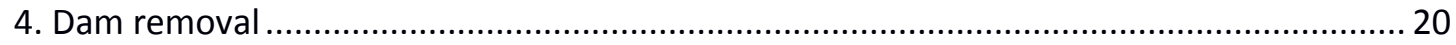

5. Ecosystem Services provided by rivers and dams and their relationship with human

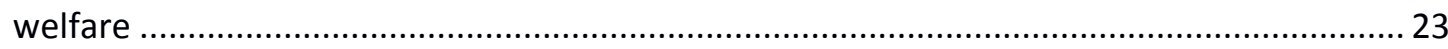

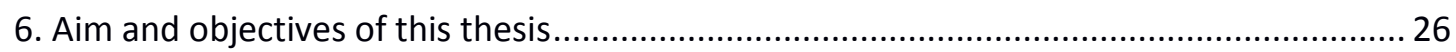

Longitudinal connectivity loss by dams in a fluvial network and the importance of considering the bidirectional passability (asymmetry) .......................................................... 28

Importance in the use of connectivity indexes to determine the river sections to be conserved and prioritize the obstacles to be removed

Fuzzy Cognitive Maps: an innovative technic to model complex systems and to simulate scenarios based on expert criteria

The importance of considering the balance of ecosystem services to measure the effects of dam removal to develop restoration management plans at basin scale................................ 33

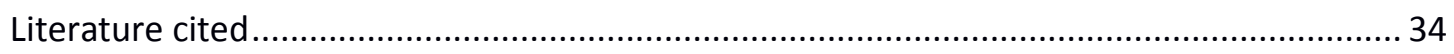

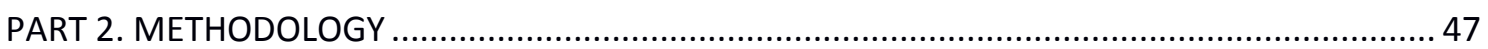

Section 1: Location and geographical context ....................................................................... 48

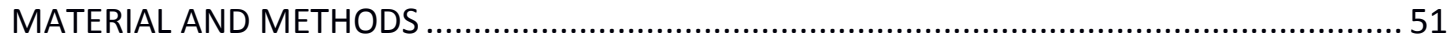

Section 2: Data collection (information used to develop the research) ................................. 51

Subsection 1: Inventory of fish communities........................................................................ 51

Subsection 2: Duero River Basin barriers inventory ……………...................................... 53

Subsection 3: Barriers classification according to ecological criteria ....................................53

Subsection 4: Conducting the interviews to the Stakeholder's and the generation of the

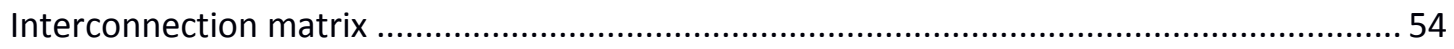

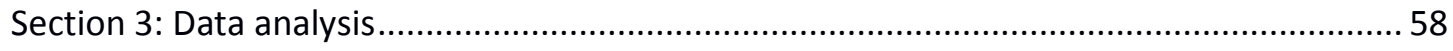


Subsection I: Use of Conefor and connectivity indices to quantify fluvial habitat

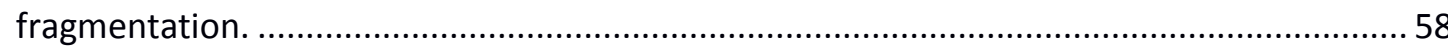

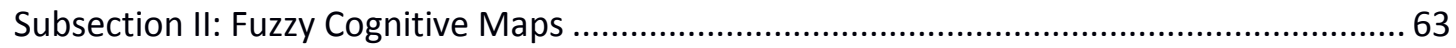

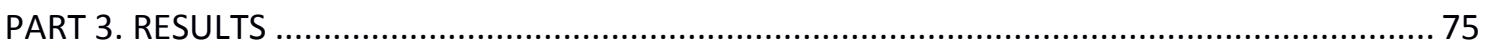

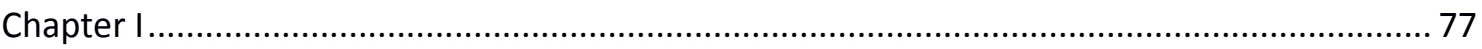

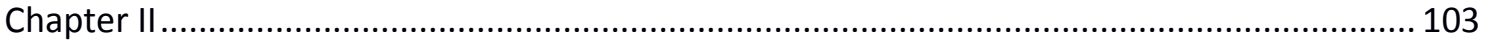

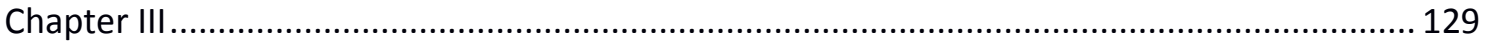

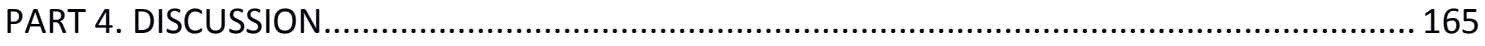

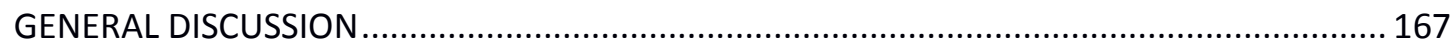

The importance of modeling the fluvial network as a graph to implement landscape

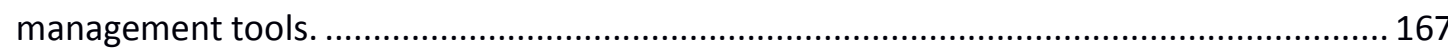

The importance of the application of Fuzzy Cognitive methods to river management. ...... 169

The importance of improving the quality of information on the inventories of obstacles in

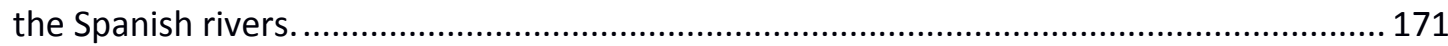

The importance of implementing dam management actions by means of the use of FCMs and the Ecosystem Services balance.

Summary of the methodological process described in chapter III through a conceptual model 176

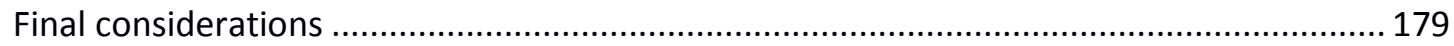

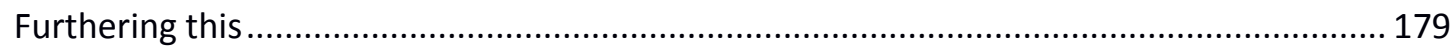

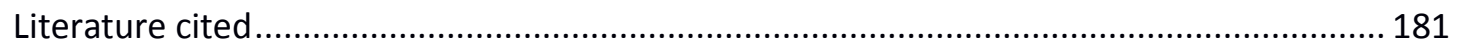

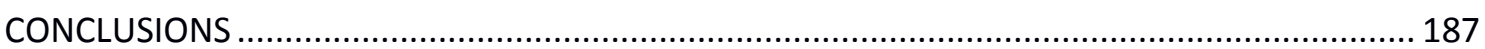

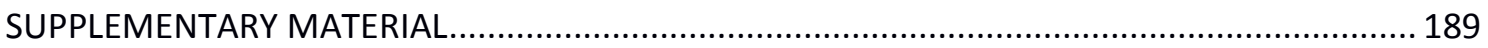

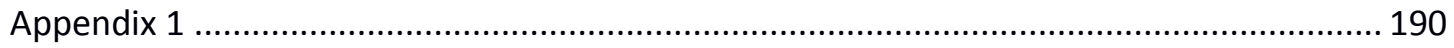

COMPLETE LIST OF PRESENTATIONS IN INTERNATIONAL CONGRESS AND OTHER

CONTRIBUTIONS DURING THE PERIOD CORRESPONDING TO THE THESIS (2014 -2019)..... 190

Appendix 2 


\section{RESUMEN}

La pérdida de conectividad longitudinal debido a la presencia de obstáculos tales como presas y azudes, así como la fragmentación del hábitat fluvial para muchas especies de peces, es uno de los principales problemas a los que se enfrentan la mayoría de los ríos del mundo. En el caso de España, este problema es especialmente evidente debido al gran número de barreras presentes en sus ríos. A esto hay que añadir que generalmente los proyectos de restauración de ecosistemas suelen contar con recursos y presupuestos limitados lo que dificulta el desarrollo de medidas eficaces de gestión. Se necesita por tanto desarrollar metodologías que permitan implementar una gestión fluvial eficaz, priorizando las actuaciones sobre los obstáculos que mayor impacto estén generando a la conectividad general de los ríos con el objetivo de enfocar los esfuerzos de restauración a la obtención de los mejores resultados posibles. Para ello se propone el uso de la teoría de grafos para modelizar la red fluvial con el objetivo de: (1) aplicar herramientas de análisis de la conectividad del paisaje a los ecosistemas fluviales para cuantificar el efecto de los obstáculos en la pérdida de conectividad sobre las comunidades de peces, (2) utilizar herramientas multicriterio como son los Mapas de Conocimiento Difuso (MCD) basados en conocimiento experto para la simulación de escenarios de gestión fluvial y la toma de decisiones, (3) mejorar la información de los inventarios de obstáculos con el objetivo de implementar una clasificación ecológica de las presas en función del uso de los parámetros (franqueabilidad, uso y materiales) que mejor clasifiquen las barreras, y (4) cuantificar el grado en que una posible gestión basada en el desmantelamiento de barreras afecta a los sistemas socio-ecológicos asociados a los ríos mediante el análisis del balance de ganancias y pérdidas de servicios ecosistémicos (SE) en escenario pre y post derribo. La aplicación de estas herramientas nos permitirá comprender mejor el efecto de las presas sobre la pérdida de conectividad longitudinal así como la importancia de su funcionamiento dentro de sistemas complejos como son los ríos, lo cual es una tarea fundamental para poder realizar medidas de gestión y restauración en el que se tengan en cuenta tanto las necesidades ambientales como las humanas.

\section{Palabras clave:}

Conectividad longitudinal, teoría de grafos, ecosistemas fluviales, barreras transversales, comunidades de peces, Mapas de Conocimiento Difuso (MCD), simulación de escenarios, modelización multicriterio, inventarios de barreras, Servicios Ecosistémicos. 


\section{ABSTRACT}

The loss of longitudinal connectivity due to the presence of obstacles such as dams and weirs, as well as the fragmentation of river habitat for many fish species, is one of the main problems faced by most rivers in the world. In the case of Spain, this problem is especially evident due to the large number of barriers located in its rivers. In addition, ecosystem restoration projects usually have limited resources and budgets, which hinder the development of effective management measures. Therefore, it is necessary to develop methodologies that allow the implementation of effective river management, prioritizing the actions on the obstacles that generate the greatest impact to the overall river connectivity in order to focus restoration efforts to obtain the best possible results. For this, the use of graph theory is proposed to model the fluvial network in order to: (1) apply landscape connectivity analysis tools to fluvial ecosystems to quantify the effect of obstacles in the loss of connectivity on fish communities, (2) use multicriteria tools such as Fuzzy Cognitive Maps (FCM) based on expert knowledge for the simulation of river management scenarios and decision making, (3) improve the information on obstacle inventories with the objective of implementing an ecological classification of dams based on the use of parameters (passability, use and materials) that best classify barriers, and (4) quantify the degree to which a possible management based on dam removal affects the socio-ecological systems associated with rivers by analyzing the balance of ecosystem services (ES) gains and losses in pre- and post-removal scenarios. The application of these tools will allow us to better understand the effect of the dams on the loss of longitudinal connectivity as well as the importance of their functioning within complex systems such as rivers, which is a fundamental task to be able to implement management and restoration measures in which both environmental and human needs are taken into account.

Keywords:

Longitudinal connectivity, graph theory, fluvial ecosystems, transversal barriers, fish communities, Fuzzy Cognitive Maps (FCM), scenario simulations, multi-criteria modeling, barrier inventories, ecosystem services. 


\section{PART 1. INTRODUCTION AND OBJECTIVES}

"El agua que tocamos en los ríos es la postrera de las que se fueron y la primera de las que vendrán; así el día presente" Leonardo da Vinci

"Intenta aprender algo sobre todo y todo sobre algo"

Thomas Henry Huxley 


\section{Rivers and longitudinal connectivity.}

Rivers are one of the most diverse ecosystems in the world because of the complexity of their processes and their high temporal and spatial variability (Branco 2013). Among the processes of the rivers, flow is the main component or overriding force (Branco 2013) responsible directly or indirectly for the operation of other ecological processes (Vannote et al., 1980; Frissell et al., 1986; Junk et al., 1989; Thorp and Delong, 1994; Fausch et al., 2002; Power et al., 1995; Poff et al., 1997; Hart and Finelli, 1999).

An essential attribute of flow related processes is connectivity. The concept of connectivity in ecosystems, both terrestrial and aquatic, can be defined as the capacity of species or populations to move among landscape elements in a mosaic of habitat types (Hilty et al., 2012) and is a fundamental property for the functioning of ecosystems (Kondolf et al., 2006). Connectivity is crucial for maintaining ecological flows of matter and energy and also the movement of genes, individuals and populations (Ward and Stanford, 1995; Nicola et al., 1996; Calabrese and Fagan, 2004; Erös et al., 2011). From the hydrological point of view, connectivity is considered as a "transfer of matter, energy and/or organisms through water within or between elements of the hydrologic cycle" (Pringle 2003). Rivers and connectivity are closely linked, to the point that they can be considered as the epitome of connectivity (Wiens 2002). Therefore, it is considered imperative to recognize and assess all the ecosystem services associated with restoring connectivity (Mitchell et al. 2013; Silva el al., 2017).

Fluvial connectivity comprises four fundamental dimensions: longitudinal dimension: the possibility of moving along the river both upstream and downstream; lateral dimension: the possibility of exchange between the channel with the adjacent riparian and floodplain areas; vertical dimension: the connection between the channel and their hyporheic zone; and temporal dimension: which comprises the time or the evolution of the river system (Ward 1989). However, fluvial connectivity is totally unidirectional for physical flows and bidirectional for biological migrations.

The development of human societies has been linked to rivers and its modifications for human purposes and benefits (Poff and Hart, 2002; Branco 2013). Likewise, it is important to emphasize the dependence on the use of the resources they provide, also known as Ecosystem Services, a concept that was established in the 70s of the last century that is gaining strength in recent years (Millennium Ecosystem Assessment 2003, 2005; de Groot et al., 2010). Accordingly, human activity has altered this water flow over time, especially through the construction of transversal barriers in order to 
have water available for their requirements when necessary, without depending on the seasonality of rivers (Poff and Hart, 2002). This implies that most of the World's Rivers have been or are currently impacted by dam presence (Nilsson et al., 2005; Zarfl et al., 2014).

The presence of barriers in rivers alters some of the dimensions of connectivity to a greater or lesser extent (although its effect on the concept of the fourth dimension is more controversial); however we have to pay special attention to the longitudinal dimension of connectivity (Ward 1989; Tockner et al., 1998; Lucas et al., 2001). Numerous studies have emphasized the alteration produced by barriers in the form of dams and weirs, not only for the fish communities (Santucci et al., 2005) but also by the alteration of the natural river flow (Bunn and Arthington, 2002, Hart et al., 2002) and the disruption of the sediment transport process (Hart et al., 2002), among other geomorphological and biophysical impacts (Stanley and Doyle, 2002; García de Leániz 2008).

Most of the Spanish territory is included within the Mediterranean climatic region, characterized by the existence of alternate cold-humid and warm-dry seasons, both influenced by a sequence of recurrent, and often extreme, flood and drought periods (Gasith and Resh, 1999). The climate peculiarities of the Mediterranean areas can be defined by a "great inter-annual variability of precipitations, pronounced seasonal variations in the rainfall regime and the coincidence of a dry period with the warmest temperatures of the summer months" (Morán-Tejeda et al., 2010). This determines seasonality in the precipitation patterns and an asynchrony in the availability of water for human uses such as consumption or agriculture (Vidal-Abarca and Suárez, 2013). For these reasons, most of the rivers in Mediterranean regions are the primary source of water (Grantham et al., 2013) and that is why they have been heavily altered by barriers (García de Jalón et al., 2007). In the Iberian region there is a large flow variability in their river systems, which are often naturally disconnected during parts of the year (Branco et al., 2012).

The native aquatic species of this region are characterized by their adaptation to this seasonality and the sequence of floods and droughts (Gasith and Resh, 1999; Branco et al., 2012; Branco 2013) and therefore have some feasibility of resistance to a certain disconnection of their habitat (Branco et al., 2012) However, the extent to which they are able to thrive in disconnected river networks highly depend on both the form and intensity of this disconnection. 


\subsection{Disconnection}

Dam presence dramatically alters the fluvial ecosystem (Poff and Hart, 2002; García de Leániz 2008; Bejarano et al., 2012) generating the river disconnection and some of its processes. Dams have been designed to alter the water flow, disrupting the upstreamdownstream linkages (Ward 1989, Poff and Hart, 2002) and therefore reducing the longitudinal connectivity. As a consequence of this, fish migrations up and downstream are hampered increasing the demographic isolation of the biological populations (Schick and Lindley, 2007). Considering that the fish communities do not have alternative paths to move along the river, fluvial ecosystems will therefore be extremely vulnerable to fragmentation (Erös and Grant, 2015). In addition, the hydrological variability of Mediterranean rivers produces unequal changes in upstream and downstream fish passabilities. For this reason determining connectivity losses in Iberian rivers is an issue (Branco et al., 2012).

Dam existence mainly affects the migratory species (Radinger and Wolter, 2014; Branco et al., 2012; Segurado et al., 2014), however it also affects resident fish species from the river reach, that cannot move along the river to complete their biological cycles (Segurado et al., 2014). Therefore, dam removal will allow the movement of these species again through the fluvial system (Hart et al., 2002). Given the decisive role of connectivity for the long-term persistence of biodiversity, it is widely acknowledged that it should be considered in decision making and in the management planning processes in landscapes and riverscapes (Erös et al., 2011).

Dams and weirs have an importance for society since they support numerous human activities such as agriculture and industry, electricity generation through hydropower production, water availability for human consumption and flood prevention (CIREF 2017). For many years, dam where considered "the panacea for floods and fire, irrigation and navigation, voltage or storage" (Babbitt 2002). For this reason, their importance has compensated the impacts that these barriers generate on rivers and their processes, so that their number has proliferated throughout the world rivers. Dams generate a transformation of the fluvial ecosystem both individually (the impact of a single barrier in a river reach) and cumulative (the problem of the presence of several successive barriers) (Poff and Hart, 2002; Kemp and O'Hanley, 2010). The excess of barriers, with the impacts that they generate, justifies the need for the study of the longitudinal connectivity loss in the Spanish river networks. 
The presence of man-made barriers amplifies the current poor ecological status of most river systems (Birnie-Gauvin et al., 2018). The EU Water Framework Directive (WFD, 2000/60/CE) considers river continuity (connectivity) as one of the aims for achieving good ecological status of the water bodies. Therefore, it is essential to develop a strategy to face the barrier excess problem and try to minimize its impact.

However, a certain degree of natural disconnection in rivers is necessary especially in the upper river reaches. This disconnection can be produced by drifting woody debris, which reduces water velocity and transport capacity, generating a temporary storage for sediments and organic matter. In this way, the biological processing enhance and uptake of nutrients is promoted (Wohl et al., 2011; Wohl and Beckman, 2014). A certain degree of disconnection in some river headwaters has importance to the stream biota, generating a state known as "fishless headwaters" where the production of energy and nutrients in the upper reaches will support other communities in lower river regions (Wipfli and Gregorovich, 2002; Rodríguez-Lozano et al., 2016).

Nevertheless, it is important to remember that this natural disconnection should be encouraged in the headwaters of certain rivers, since at the watershed level, the specialists recommend encouraging the improvement of connectivity (Wohl and Beckman, 2014).

The present research arises from analyzing the problem of loss of longitudinal connectivity or fluvial fragmentation due to the large number of transverse barriers (both dams and weirs) located in the rivers. This research is considered necessary to respond to the challenges and demands of a society that needs fluvial resources, but at the same time should ensure that its use does not entail degradation that leads to a loss of the ecological potential of fluvial systems.

\section{The application of graph theory as an opportunity to manage the fragmentation problem.}

Graph theory is, considering a simplified definition, the study of a graph. More specifically, it is a mathematical approach based in the consideration of a collection of points or nodes and lines or edges (Harary and Norman, 1953; Barnes and Harary, 1983). If the connection between nodes is directed, the representation is considered as a directed graph or digraph (Harary and Norman, 1953). The first use of signed digraphs was made by Axelrod (1976) to represent the causal relationships between variables with the knowledge of the social scientific knowledge (Kosko 1986). Approaches based in graph theory have been widely used in the field of the social 
sciences and psychology (Harary and Norman, 1953) and in other disciplines such us computer sciences, geography and information technology (Bunn et al., 2000).

Urban and Keitt (2001) considered that there are two data structures to represent landscapes that are familiar to ecologists: vector-based maps that delineate land cover types as polygons and raster lattices that consider the landscape as a grid. Therefore, they adopt a third lattice structure for the representation of the landscape: the graph.

In an ecological context, graph theory begun to be used at the assessment of fragmented habitats and to highlight patches for conservation (Keitt et al., 1997, Bunn et al., 2000, Urban and Keitt, 2001). The advantage of a graph-theoretic approach compared to other landscape and population modelling techniques is that graph theory incorporates connectivity and computationally eases with minimal data requirements (Bunn et al., 2000; Minor and Urban, 2007). In the last decade, this methodology has been widely used in terrestrial ecological studies (Minor and Urban, 2007, 2008; Dale and Fortin, 2010; Bodin and Saura, 2010; Saura and Rubio, 2010), and has proven to be useful to analyze metapopulation models trough a simple spatial explicit representation (Brooks 2006).

In the case of aquatic systems, graph theory methods have not been applied until recently (Schick and Lindley, 2007; Erös et al., 2011, 2012; Segurado et al., 2013, 2014), proving their usefulness to model connectivity where the directionality in the movement of fish species is very limited to the river channel itself.

\subsection{The importance of applying modelling tools in fluvial ecology}

River systems are highly socio-ecological complex systems. In particular, human activities in Mediterranean fluvial ecosystems have always been difficult to manage due to the large number of natural and human factors that affect them. So, in order to unravel this complexity, it is necessary to use methodological tools that allow us to obtain realistic answers from systems where not all the information is available.

There is a need to integrate knowledge among disciplines, sectors and social actors to understand ecological systems, without forgetting that potential participants have knowledge and partial experience of the relevant aspects of the topic (Ulrich 1993; Gibbons et al., 1994; Helfgott et al., 2015). Mathematical modelling is highly recommended to forecast possible responses to alterations or changes, but we do not always have enough information to do it. In these cases, the soft and meta-models can be valid alternatives to simulate these complex systems. 
For a better combination between the use of the available information and the knowledge integrated by the stakeholders or participating experts, we propose the use of multi-step fuzzy cognitive maps (FCMs) among other ecosystem modeling tools for their ability to (1) analyze how a complex system (i.e. fluvial ecosystem) is perceived by people; (2) identify, compare and contrast the individual and group perceptions of the stakeholders; (3) combine qualitative and quantitative information (inputs and outputs) and (4) generate comprehensive models that can be easily managed by decision makers and that serve to generate environmental management policies (Özesmi and Özesmi, 2004; Kontogianni et al., 2012; Papageorgiou and Kontogianni, 2012; Helfgott et al., 2015).

\subsection{Applications of FCMs in ecology}

In the last thirty years, the FCM approach has been applied as a Multi Criteria Decision Method in industrial engineering and management (Stylios and Groumpos, 2004), business and management (Jetter 2006; Yaman and Polat, 2009), medicine (Papageorgiou et al., 2003; Stylios et al., 2008) and agricultural and territorial planning (Özesmi and Özesmi, 2004; Markinos et al., 2007; Papageorgiou et al., 2009). In environmental management, the use of the FCM was recently implemented. One of the first applications was represented by the use of a methodology based in the stakeholder decision-making process to predict the efficacy of the management of sport-fishery actions (Radomski and Goeman, 1996). Silvert (1997) quantified the complex process of classifying the ecological impacts of human activities through the fuzzy set theory. Fuzzy indices of environmental conditions were used by Silvert (2000) to classify and quantify the environmental effects of a subjective nature to assess the effects of finfish mariculture on the quality of coastal zone water. Özesmi and Özesmi (2001) used a FCM methodology to determine the demands of local people regarding their resettlement and welfare during and after the construction of a large hydroelectric dam. In a similar way, Dadaser and Özesmi (2001) used the FCM to determine the opinions of different stakeholders groups in a wetland area in Turkey. Hobbs et al. (2002) applied the FCM to the management of Lake Eire using the information provided by different stakeholder groups (scientists, managers, and the public) of this complex ecosystem (more than 160 variables obtained). Likewise, Liou et al. (2003) applied a two-stage fuzzy set theory to efficiently condense the monitoring data for evaluating the trends in river quality in Taiwan. The FCMs can be combined with other methodologies, such us GIS, to predict plant habitat availability in forest using expert knowledge, as explained in Skov and Svenning (2003). Mendoza and Prabhu (2003) used a multi-criteria analysis as a decision making tool to assess 
indicators of sustainable forest resource management. Özesmi and Özesmi (2003) utilized a FCM to create a participatory management plan by analysing the perceptions of a group of stakeholders about a lake ecosystem. In addition, Özesmi and Özesmi (2004) proposed a multi-step fuzzy cognitive mapping approach to create an ecological model that combined both expert and local people's knowledge to analyse ecological problems. The use of expert knowledge in a particular ecological field was the reason why Tan and Özesmi (2006) generated a FCM that developed a generic shallow lake ecosystem model. Mouratiadou and Moran (2007) used the FCM to determine stakeholder's perceptions about the current state and pressures on water resources and to develop a simulation of different management policy options. Kok (2009) introduced the FCM as a semi-quantitative tool to determine the future dynamics of deforestation in the Brazilian Amazon. Papageorgiou and Kontogianni (2012) were the first to the use of the FCMs in environmental decision making and management, and Kontogianni et al., (2012) used this application to develop a methodology that revealed perceptions of local populations about the resilience of the Black Sea ecosystem. Wildenberg et al., (2014) examined the strengths and weaknesses of applying FCMs as a tool in the conservation management of socio-ecological systems. Lorenz et al. (2015) presented a conceptual meta-analysis identifying the most relevant hydromorphological processes and variables in rivers, and they used a FCM to generate a model that predicted the interactions between pressures, processes and variables. Vasslides and Jensen (2016) used FCMs to develop conceptual models of a complex estuarine system among different stakeholder groups. Finally, van Vliet et al. (2017) used the FCMs as a tool to provide a common base for stakeholders and modellers for water management and scenario development in different Mediterranean river basins.

\section{Improvement of the existing information on barriers}

One of the first obstacles to the implementation of management measures to improve longitudinal connectivity is the definition of what is considered a barrier. A broad definition of barrier would be: "a thing that modifies the flow of water, the transport of sediments or the movement of organisms along the river" (García de Leániz, personal communication). This concept of barrier would include those that preclude the active movements of organisms, but also passive drift of debris and sediment transport. If the integrity of natural processes is the object to be measured, only artificial barriers that suppose a physical alteration of flow movement along the river should be considered. There are natural barriers as waterfalls and other elements of 
the landscape orography, or even more subtle barriers that can hinder the movement of fish such as changes in water temperature or/and salinity in a particular river stretch can be considered (Ern et al., 2014). However, a certain disconnection due to natural barriers would be an important attribute of natural river networks, and therefore should not be considered as an alteration of ecological integrity.

Usually, only large dams have been considered barriers for the inventories of obstacles, whose number and location is generally well known (MOPU 1986; MITECO 2019). The existence of more than 1,200 large dams in the Spanish rivers is documented (MAPAMA 2016), being one of the countries with the largest number of dams per km of channel (Vidal-Abarca and Suárez, 2013). Despite this, this data is outnumbered by the presence of small dams and weirs (Lucas et al., 2009), built for different purposes (Silva et al., 2017), many of which are not currently fulfilling the purpose for which they were designed, and others being currently abandoned, damaged or out of service (Rincón et al., in prep). The data obtained from the dams and weirs inventories of the different Spanish River Basin Districts determine the existence of some 18,000 barriers (Figure 1), although it is estimated that many of these inventories are not complete, so the number could be much higher (CIREF 2017).

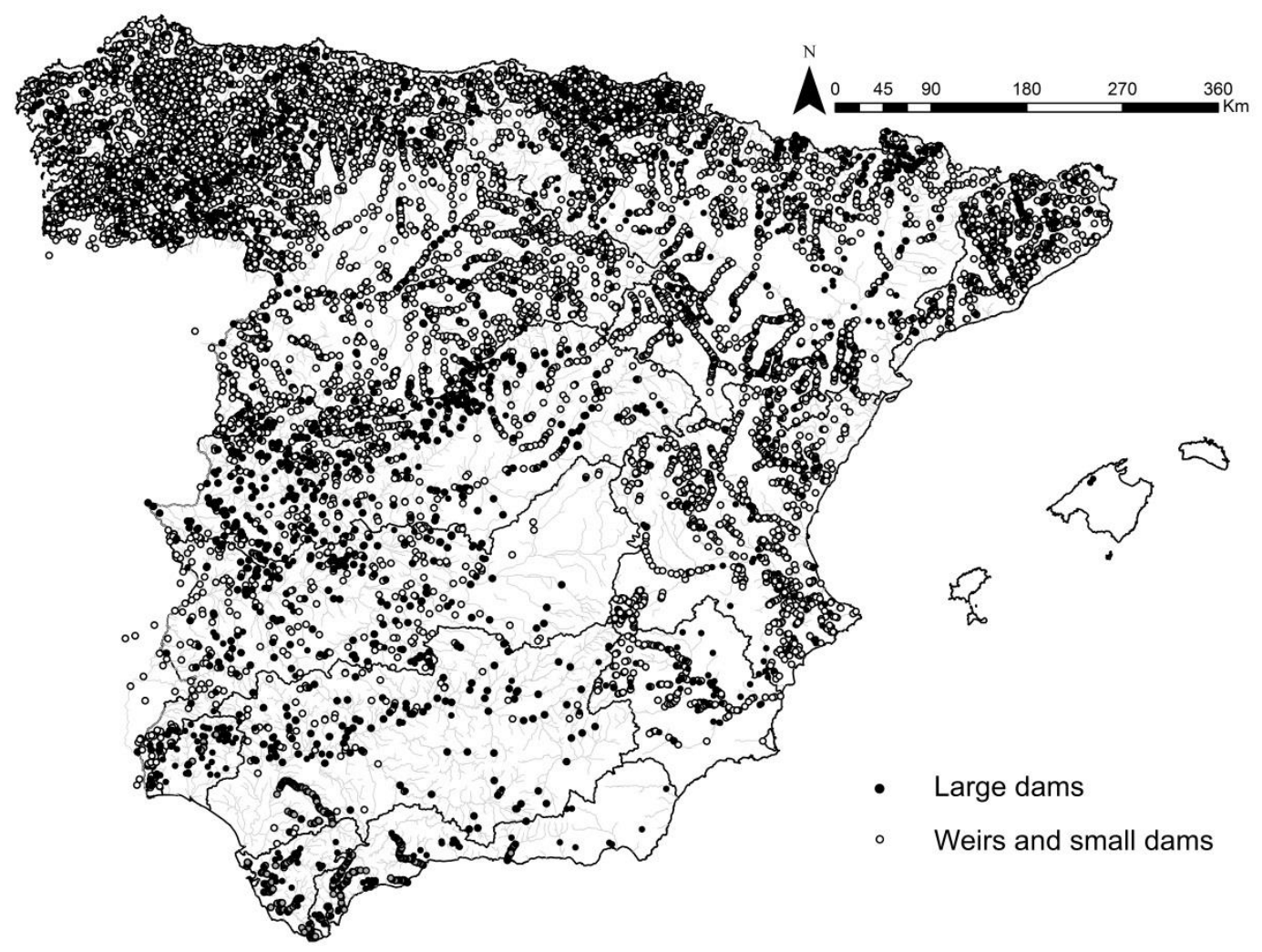

Figure 1. Location of the dams and weirs in the Spanish rivers according to the data provided by the different basin authorities. Adapted from CIREF (2017) 
Surprisingly, despite of these large numbers of barriers, dam inventories have not been implemented in the same way in each basin region so there is still uncertainty about the location of many of the obstacles located in Spanish rivers, especially when it comes to small weirs. In addition, some of these inventories collect very different information from each other, which hinders their systematization under a common criterion. This may be due to multiple factors, among which is a lack of environmental control, a miss of cooperation between the different public authorities responsible for river management (CIREF 2017) and a shortage in following the use of natural resources by the power companies.

The existence of incomplete inventories is a problem for the evaluation of the impact that these barriers generate in the rivers, and becomes an obstacle for decision makers to guide restoration efforts at the river basin level, such as the prioritization of barriers in which action, including removal, may be needed (Kemp and O'Hanley, 2010; Januchowski-Hartley et al., 2013; Branco et al. 2014).

The improvement of the available information on the location and on certain characteristics with ecological importance is a crucial issue. The existence of barrier inventories as complete as possible and accessible to the public is essential to represent the fragmentation problem in our rivers, so that society will be aware of this problem (Kemp and O'Hanley, 2010, CIREF 2017).

For this thesis a classification of the Duero River Basin obstacles has been made according to ecological criteria in order to increase the potential for the restoration of regulated rivers (Poff and Hart, 2002). This classification is very important in hydrological planning at the basin level in order to implement an adaptive management of existing barriers.

\section{Dam removal}

Most of the dams were built before incorporating environmental considerations in project decision-making. Nowadays, some of these dams would not be built because their environmental costs exceed their benefits (Pejchar and Warner, 2001). Unfortunately, the disconnection problem generated by the obstacles already built is an issue and needs the application of plans to minimize its impact.

One of the most widely used measures to reduce the impact on longitudinal connectivity caused by barriers has been the permeabilization of these obstacles through the installation of fishpasses (Larinier 2001). The main objective of these 
structures is to promote the sustaining of aquatic ecosystems through the maintenance or reconnection of ecological connectivity (Silva et al., 2017). However, several problems have been described regarding the installation and use of the fishpasses (Calles and Greenberg, 2009). Problems such as the inadequate design of the fishway among other factors have determined that some fishpasses are not functional or fulfill the purpose for which they were designed (Bunt et al., 2012). Moreover the ladder deals only with the problem of the movement of fish communities without taking into account other alterations that barriers generate. Despite, these structures can be a solution when there are no other management alternatives to recover longitudinal connectivity.

An alternative to improve the longitudinal connectivity of the rivers which also recovers other altered processes is the removal, which can be total or partial, of the barrier itself. In 2002, Poff and Hart talked about the emerging science of dam removal. They also forecasted that the aging of the dams, along with their increasing maintenance cost throughout their lifespan, will ensure that the practice of barrier removal will continue to increase in the near future. Some circumstances have changed since then, and the debate about the need to establish measures to implement the option of removing barriers as an effective restoration methodology is currently hotly.

Very often the decision of not to intervene has been taken when a barrier has reached the end of its useful life or has become obsolete and is no longer generating any benefit for human purposes. However, it is estimated that the cost of doing nothing with the obstacle (i.e. not restoring connectivity) supposes a loss in the global benefits it provides that can outweigh even the price value of performing one of these two actions (Silva et al., 2017).

Due to the difficulty of implementing dam removal actions as a usual element in restoration projects, a first step would be the ecological classification of dams to characterize how the huge variation in the size, operational mode, age, and number of dams in a river basin, which influences the potential for restoring regulated rivers via dam removal (Poff and Hart, 2002).

According to Hart et al. (2002), most of the impacts generated by a dam will be reversed after its removal given the enough amount of time. Unfortunately, there are still few study cases of dam removal in the world in general (see Bednarek 2001; Poff and Hart, 2002; Hill et al., 2019 for more cases in the United States or Birnie-Gauvin et 
al., 2018 for weir removal cases in Europe) and in Spain in particular (CIREF 2017); and most of them have not monitored the ecological evolution after the removal. Therefore, one drawback of the dam removal proposal is that not enough time has passed to quantify the benefits of this approach on the fluvial system, considering that some processes will recover before others (Hart et al., 2002).

In our country, the implementation of the National Strategy for River Restoration (NSRR) is highlighted as a milestone in the dam removal actions. This strategy arises in compliance with the WFD, with the objective of restoring river connectivity and achieving the good ecological status of water bodies (MAGRAMA 2012; CIREF 2017). Under this strategy, numerous obstacle permeabilization measures were developed, such as the construction of fish passage structures or the removal of some weirs and dams, as well as other measures of fluvial restoration and recovery of riparian vegetation. There is evidence that the removal of barriers began in 2006 and continued until at least 2016 (CIREF 2017), being between 2009 and 2011 the time of greatest activity with the elimination of 129 dams in different regions (Rodeles et al., 2017). The application of this strategy has occurred irregularly in each different River Basin District, being in the Duero River Basin where the greatest number of barriers was removed during this period of time (CIREF 2017).

Nevertheless, we cannot forget the importance of barriers in human development. It has been seen that in some cases the local population has protested against initiatives to eliminate some particular barrier, considering it part of their culture and their lives (Fox et al., 2016). So, to avoid present and future conflicts with the society we should be more assertive when explaining the problem of the over-presence of barriers in our rivers and the advantages of incorporating dam removal as a fluvial restoration technique.

We should be aware that dam removal actions can have negative effects in some fluvial processes (Poeppl et al., 2019). For example, problems with an uncertain distribution of sediments downstream the dam in a short period of time after the removal can occur (Hart et al., 2002; Poff and Hart, 2002; Ibisate et al., 2016). Also, dam removal actions can allow the free circulation of invasive alien species (especially fish species) that can colonize habitats that were previously out of reach by the presence of the barrier (Fausch et al., 2009). However, these possible effects have not yet been described in detail due to the absence of monitoring pre and post removal in the case studies carried out in Spanish rivers so far (CIREF 2017). 
An interesting analogy proposed by Hart et al. (2002) states that most of the adverse effects that can occur after the elimination of a barrier are probably transient and that therefore can be considered as the short recovery time similar to that which occurs after a surgery. Dam removal is a good restoration tool to be used whenever possible but it is only one of the many potential and practical tools, which implies that this range of options should be taken into account in order to achieve a better combination of methods for get integrated management goals (Hart et al., 2002).

"Some dams are better candidates for removal than others" (Babbitt 2002). However, it is still necessary to implement new tools such as those described in this thesis that help to identify what these key barriers will be. According to the NSRR Guidelines, the criterion to removal dams is their obsolescence; however there is hardly any information available on this data (Rodeles et al., 2017). Therefore, other criteria are also needed to effectively implement river restoration actions based on the removal of barriers in our country.

\section{Ecosystem Services provided by rivers and dams and their relationship with human welfare}

If we want to evaluate the balance of benefits and damages that a human infrastructure produces, such as dams, we have to include in a balance what is gained and lost both for nature and for human beings and their activities. The concept of ecosystem services includes both, for that reason we consider its use interesting for the study of the impacts of the dams and the effects that may occur if it is decided to remove them.

"Ecosystem Services are the benefits people obtain from ecosystems" (Millennium Ecosystem Assessment 2003, 2005). Human well-being depends on the correct functioning of ecosystems, as long as all goods and services we use are ultimately obtained from ecological structures and processes (Jax et al., 2013). This concept has been kept in mind since ancient times; however its definition is relatively recent (Mooney and Ehrlich, 1997). From an anthropocentric perspective, this concept assumes a framework in which the biophysical elements of the ecosystems can be used in terms of human well-being (Mooney and Ehrlich, 1997, Brauman et al., 2007) and represent the relative contribution of natural capital to human well-being (Costanza et al., 2014). However, ecosystem services do not flow directly from natural capital to human well-being. Natural capital can provide benefits through the interaction with human capital (people), social capital (their communities), and built 
capital (their built environment) (Costanza et al., 2014). For this reason "the ecosystem services framework links conservation and development by relating environmental health to human health, security, and material goods necessary for well-being" (Brauman et al., 2007).

Ecosystem services can be divided into the following main groups (Millennium Ecosystem Assessment 2005, hereafter MA):

1. Provisioning: services that provide goods such as food, water, timber and fiber for direct human use.

2. Regulating: services that affect climate, floods, diseases, wastes and water quality.

3. Cultural: services that provide recreational, aesthetic and spiritual benefits.

A fourth type of services can also be considered called Supporting services such as soil formation, photosynthesis and nutrient cycling among other, that represent the underlying ecosystem processes which will serve as a basis for the other three services described above.

The MA also examines how the Ecosystem Services influence human well-being, a concept assumed to have multiple constituents grouped into four sections:

1. Security: a concept that includes the ability to live in an environmentally clean and safe shelter and the ability to reduce vulnerability to ecological shocks and stress.

2. Materials for a good life: a concept that includes the ability to access goods and resources to earn income and gain an adequate livelihood.

3. Health: a concept that includes the ability to achieve good quality of life through the access to a healthy physical environment.

4. Social relations: a concept that includes social cohesion, mutual respect and the opportunity to express aesthetic, cultural and spiritual values associated with ecosystems and the opportunity to observe, study and learn about fluvial ecosystems.

The joint expression of these sections leads to a category known as Freedom of choice and action that encompasses the characteristics of the four groups. Relationships between Ecosystem Services and constituents of human well-being are shown in Figure 2. 


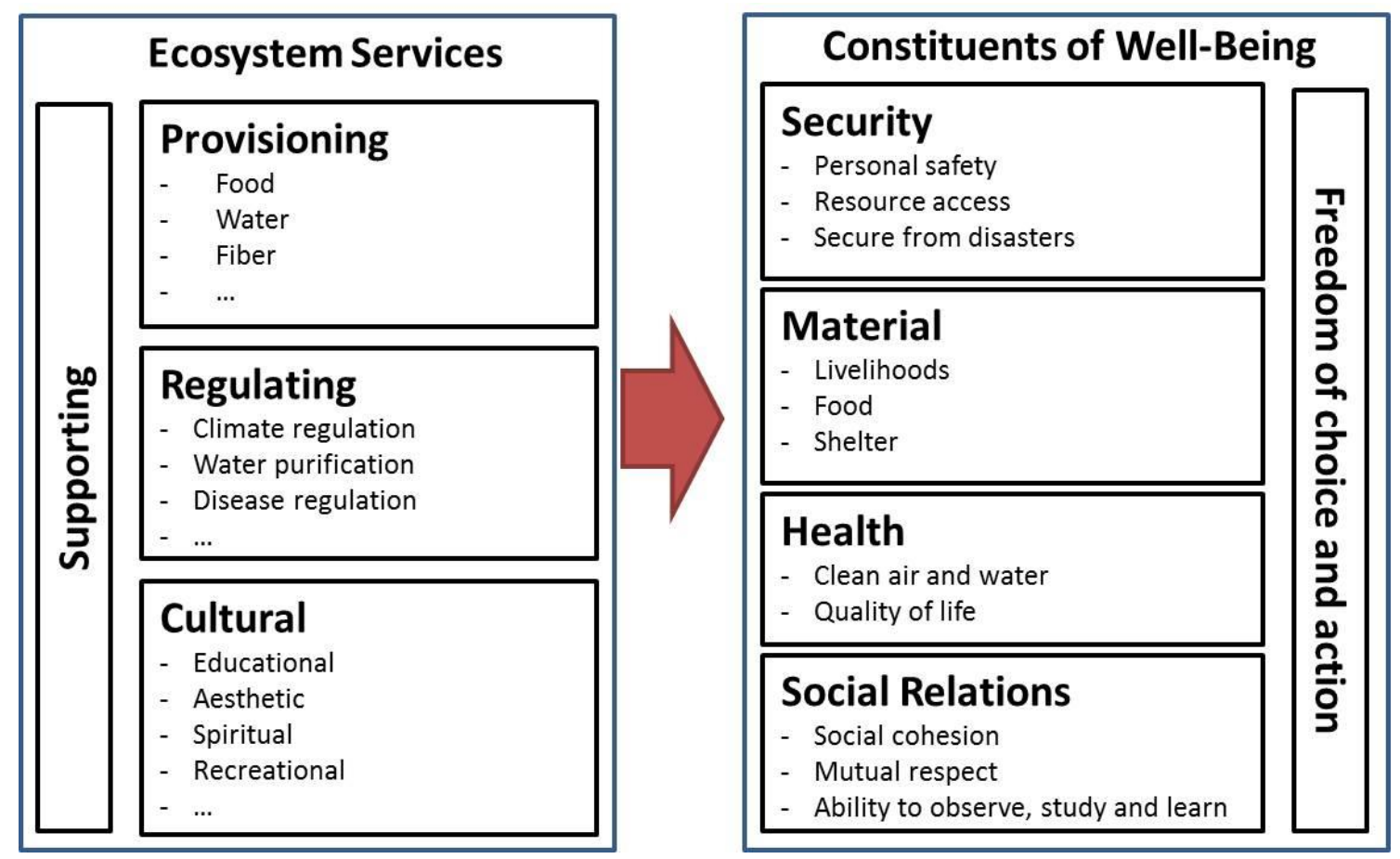

Figure 2. Schematic representation of Ecosystem Services and their relationship with the constituents of human well-being. Adapted from the Millennium Ecosystem Assessment classification (2003, 2005) and Brauman et al., 2007.

One of the most important contributions of the MA to the Ecosystem Services framework was the documentation of their current state and future trends (Millenium Ecosystem Assessment 2005). But it is important to know that these services have an important geographical variation which complicates predicting the actual impact of human populations (Brauman et al., 2007).

In a general context, ecosystems have been modified by human action with the aim of producing ecosystem services such as food, water, timber and fiber (Bennet et al., 2009). However, these transformations have overlooked the complex and dynamics interrelations (feedbacks and trade-offs) among the multiple ecosystem services produced by landscapes and human beneficiaries (Peterson et al., 2003; Chan et al., 2006; Rodríguez et al., 2006; Brauman et al., 2007). It is usually the case that the modification of ecosystems to improve only a certain service it is generally done at the expense of degrading other services, which can affect different human groups in different ways (Bass 2006).

Rivers are ecological systems whose functioning represents a natural capital that can satisfy some human welfare needs through the provision of ES. Dams are devices (built capital) that allow society to make natural capital generate important ecosystem services: freshwater and energy provisioning services, mainly, but also flood control, 
navigation, and recreational opportunities (Bednarek 2001). But, at the same time, the modification of the natural fluvial systems prevent that natural capital from satisfying other human needs or reducing other ecosystem services (e. g., regulating and cultural services) (Gilvear et al., 2013). The ecosystem services generated by fluvial ecosystems will be described in more detail in chapter III of this thesis.

\section{Aim and objectives of this thesis}

In this general context, this thesis aims at contributing to a better understanding of the longitudinal connectivity disruption problem in the Spanish rivers by cross-sectional barriers. For this purpose, modeling techniques and management methodologies based on graph theory are proposed:

(1) to quantify the effect of this disconnection on fish communities, and

(2) to implement multi-criteria tools based on decision-making based on widely recognized scientific and social concepts. This will be done by assessing the advantages of barrier removal as the most effective measure to restore longitudinal connectivity and the natural processes of the river.

My research addresses three main topics. First, an application of the graph theory to model a river network affected by the presence of dams and weirs to assess their impact on fish upstream and downstream movement. In this case, we need to quantify the effect of all barriers in the river network and not only large ones. The objective is to rank the obstacles that cause the most fragmentation and therefore prioritize management or restoration measures. We also determine the river sections that are most sensitive to this fragmentation (Rincón et al., 2017). Second, the need to use methodologies for the analysis of complex systems, with a great variety of variables and information that is not always available, has led us to adapt a methodology based in graph theory and fuzzy logic to measure known as Fuzzy Cognitive Maps (Kosko 1986). Rivers are affected by multiple pressures and it is difficult to determine how far in the chain of ecological processes some of them reach. Therefore it is necessary to implement methodologies that use the knowledge of stakeholders in fluvial issues to develop future management scenarios (Solana-Gutiérrez et al., 2017). And third, both approaches have been combined to design a methodology to quantify the general effect of dam removal in a large river basin. For this purpose, ecosystem services and their influence in the Constituents of human well-being have been used to measure this balance of positive and negative effects, taking into account the array of interrelations between them. Different management scenarios have been developed 
in an innovative way considering a systematic classification of the different types of the obstacles in the Duero River Basin determining the groups of obstacles that generate the greatest impact by altering the gain/loss balance of ecosystem services that are currently providing rivers altered by the presence of barriers (Rincón et al., submitted).

The general objectives of this research are the following:

- To characterize the current state of the fragmentation of Duero Basin rivers by the presence of artificial barriers such as dams and weirs.

- To quantify the loss of longitudinal connectivity by assessing the passability of each obstacle and the movement capacity of fish species in two directions: upstream and downstream of the barrier.

- To produce a barrier ranking attending to their impact on the global longitudinal connectivity of the basin based on the application of habitat connectivity indexes.

- To design a methodology based on Fuzzy Cognitive Maps (FCMs) and expert knowledge for the simulation of fluvial management scenarios and decision making in river restoration.

- To improve the classification of the barriers of the Duero basin according to selected parameters (passability, use and building materials) that allow establishing better measures for an ecological classification and their adaptive management.

- To use the ecosystem services that are being provided by rivers in combination with the FCMs methodology to generate management scenarios based on the removal of selected barriers in the Duero Basin rivers.

- To compare the balance of ecosystem services in the pre- and post-removal scenarios to determine the groups of barriers that have the highest impact on this balance, and to establish management measures at the basin level.

This document is structured into four chapters: (1) the general context in which the thesis has been developed; (2) a general methodological description; (3) the results distributed three sections correspondent to three research articles; and (4) a general discussion and conclusions.

The core of this thesis is a collection of three articles that address some relevant questions:

(1) Longitudinal connectivity loss by dams in a fluvial network and the importance of considering the bidirectional passability (asymmetry) (art 1.). 
(2) Importance in the use of connectivity indexes to determine the river sections to be conserved and prioritize the obstacles to be removed (art. 1).

(3) Fuzzy Cognitive Maps: an innovative technic to modelling complex systems and manage scenario simulation based in expert criteria (art. 2).

(4) The importance of considering the ecosystem services balance based on Fuzzy Cognitive Maps to measure the effects of dam removal to develop restoration management plans at basin scale (art. 3).

Questions 1 and 2 have been addressed in article 1; and questions 3 and 4 have been addressed in articles 2 and 3, respectively.

In the following lines I present an insight to these questions and how they are approached in the articles; although more detailed descriptions are presented in the Materials and Methods section.

\section{Longitudinal connectivity loss by dams in a fluvial network and the importance of considering the bidirectional passability (asymmetry).}

One of the major concerns in the rivers of the world is the disruption of longitudinal connectivity. This alteration is mainly due to the presence of cross-sectional barriers such as dams and weirs which are precluding the movement of fish communities. Traditionally, only the hindrance of the fish movement upstream barriers has been considered and therefore the study of disconnection was limited exclusively to large dams (Calles and Greenberg, 2009; Erös et al., 2011, 2012 and Segurado et al., 2012, 2014). Nevertheless, it is important to consider the effect of every obstacle in the river network since even small weirs can have significant effects on fluvial processes (Larinier 2001; Hart et al., 2002; García de Leániz 2008).

The approaches based on graph theory to analyze the functional connectivity of a freshwater system have proved to be very useful tools (Schick and Lindley, 2007; Erös et al., 2011, 2012; Carranza et al., 2012, Segurado et al., 2013). Graph theory allows us to represent river systems as graphs or networks that contain nodes depicting individual elements and links representing relationships between the nodes (Bodin 2009; Erös et al., 2012). In this way, river segments and barriers can be represented in the graph, and their individual importance in the overall connectivity of the river system can be assessed. This approach offers advantages such as the ease of representing a complex river network and all its obstacles in a simple, elegant and easy manner to interpret. 
Traditionally, in connectivity studies applied to terrestrial ecology or landscapes, graph theory has been used to represent habitat patches as nodes and the possible paths between them as links or junctions (Minor and Urban, 2007, 2008; Bodin and Saura, 2010; Saura and Rubio, 2010). This conception has also been used in some studies of longitudinal connectivity altered by dams in fluvial ecology (Erös et al., 2011; Segurado et al., 2013, 2014). For the hydrological modelling of freshwater systems it is useful to consider the stream segments as nodes with an amount of associated habitat. These nodes are joined by links or connections with different strengths (passabilities) that can be headwaters, confluences (river junctions), the river mouth and barriers (dams and weirs).

Previous studies based in graph theory to quantify longitudinal connectivity loss have relied in the assumptions that barrier passability values are binary (or impassable or totally passable) and the non-directionality of the movement across barriers (see Erös et al., 2011; Segurado et al., 2013, 2014). I would like to point out that this form does not fit well with the nature of the rivers. Therefore I propose a new approach considering asymmetry, which is an extremely important concept in the analyses of metapopulations in rivers and possible biases in the upstream-downstream movements (Grant 2011). The consideration of directionality in riverine networks is needed in order to build up more ecologically realistic and functional models (Padgham and Webb, 2010). The asymmetry of the movement for each obstacle has been considered according to the inventory of obstacles made by González Fernández et al. (2010) in the study "Longitudinal connectivity diagnosis in the Duero River Basin".

The fish community of the study area also has to be described because the passability of the obstacles depends fundamentally on the physical parameters of each obstacle and the swimming capacity of the fish species in both directions (Cote et al., 2009; Bourne et al., 2011; Januchowski-Hartley et al., 2013).

At this point, my research is aimed at (1) converting the fluvial network into a graph were nodes are the river reaches with suitable habitat for fish, and the junctions between nodes (barriers) are considered as connectors between river segments; and (2) considering that the movement of fish is asymmetric and bi-directional (upstream and downstream) as their pasability is (Chapter I). 


\section{Importance in the use of connectivity indexes to determine the river sections to be conserved and prioritize the obstacles to be removed}

The budgetary restrictions of river restoration programs make it necessary to apply efficient methods that maximize the benefits for the riverine network functioning (Rivers-Moore et al., 2016). The graph-based approach also allows us to determine the key river sections to preserve according to its importance in the river network. At the same time, they allow to rank the obstacles according to their impact on the overall connectivity of a basin. The obstacles that produce the highest impact should be prioritized in the restoration programs.

To do this, I applied a graph-based approach to account for asymmetrical passability in river connectivity assessments obtaining different graph resolutions to prioritise barriers. Among the landscape connectivity indexes, the most widely used to quantifying the loss of overall connectivity produced by barriers in a river system are mainly two: the Integral Index of Connectivity (IIC) (Pascual-Hortal and Saura, 2006), which relies in binary barriers, and the Probability of Connectivity (PC) (Saura and Pascual-Hortal, 2007), which allows for a continuous range of passability values to be assigned to each barrier. I used a directional version of the Probability of connectivity (PC) metric considering both upstream and downstream passability for each barrier. One of my subsidiary objectives was to compare both indexes to determine which one is the best when analyzing the problem of fragmentation in real fluvial networks.

To verify the possible error of not assuming asymmetry in studies of longitudinal connectivity in rivers, two scenarios were evaluated: (1) assuming symmetry in the passability of every obstacle; and (2) considering the asymmetry of the barriers when present, which is the most realistic situation. Higher values of overall connectivity were expected to occur when obstacles have different passability values in both directions. This analysis was done using the Conefor software, a tool that was designed for studies of these characteristics (Saura and Torné, 2009). Furthermore, the PC for asymmetric graphs was computed using an ad hoc version of the Conefor (the command line software version). A detailed description of the operation and use of this tool can be seen in the Material and Methods section.

The contribution of each node (river segment) to the overall connectivity was assessed by calculating the percent variation in the values of the indices after removal of that particular segment from the river network. On the other hand, evaluating the contribution of each link allows us to determine the effects on the connectivity of the 
removal of an obstacle (dam or weir). In a riverine network, only the pairs of segments with a direct connection between them were considered. Both the IIC and the PC indices determined which of the river segments are the most sensitive to the loss of connectivity and thus the most valuable when removing or permeabilising the dams that are affecting them.

This section is aimed at (1) using a more intuitive connectivity index to accurately determine the passability of each obstacle in both directions based on the passability that already exists; (2) testing the most used landscape connectivity indexes to determine which is the most appropriate to use for the evaluation of the alteration of longitudinal connectivity in rivers affected by both symmetrical and asymmetric barriers to fish movement; and (3) identifying the most important river segments to preserve and generating a ranking as reliable as possible of the obstacles that should be removed first to recover the maximum possible connectivity with the least use of economic resources (Chapter I).

\section{Fuzzy Cognitive Maps: an innovative technic to model complex systems and to simulate scenarios based on expert criteria}

The management of human actions in river ecosystems affects a variety of social groups such as users, managers, policy makers, etc. who have different interests about the use of water and fluvial issues (Eshuis and Stuiver, 2005; Rinaudo and Garin, 2005). To avert conflicts, modelling can help to forecast the participation of these stakeholders to reach a sustainable management of river systems as providers of goods and services. However, the complexity of the processes and the absence of information can be a problem when implementing quantitative models. So, it is necessary to propose soft models as valuable alternatives to simulate complex systems.

To develop a river management plan based on both public participation and expert knowledge, I used Fuzzy Cognitive Maps (hereafter FCMs) as a semi-quantitative model tool. It provides a structured, simple and inexpensive way to model overall fluvial systems through a soft evaluation of the relationship between different concepts and factors interpreted by stakeholders (Giordano et al., 2005; Papageorgiou et al., 2009; Malek 2017; Paolisso and Trombley, 2017).

The FCMs (Kosko 1987) are based on graph theory, that is, it is modeled by a graph oriented by nodes (concepts or variables) and lines related to the causal relationships between the concepts (links). FCMs can be described as a qualitative model that 
depicts how a given system operates (Özesmi and Özesmi, 2004). The main variables of the system, as well as the causal relationships between them, are encoded into individual maps. To generate these maps, the knowledge from a panel of representatives of different social sectors experts can be obtained by interviews. Once all the individual maps are obtained, they are grouped to generate an aggregated FCM, which then establishes the importance of the variables analyzed and the strength of the causal relationships between them. I have applied the FCMs to a specific case study in order to evaluate the potential of this tool to help managers when making decisions in fluvial management (Chapter II).

Another important reason for choosing the FCM methodology is that they can be used to analyse the system behaviour by running simulations and to determine future possible management scenarios, which can serve to guide environmental managers in the decision-making process regarding the objective system, in this case the river system.

The implementation of management scenarios allows us to simulate different situations by asking "what-if" questions to determine the response of the system under different conditions (Kosko 1987). In my study, two opposed scenarios were proposed: an increase of the river fragmentation by the placement of new barriers (scenario 1); and an increase of longitudinal connectivity through a dam removal management plan (scenario 2).

Before considering any simulation process, the FCM methodology gives us a steady state according to the opinion of the stakeholder's participant. Then, some variables were modified to measure the response of the whole set of variables to this change through a sensitivity analysis.

This section of the thesis contributed to face the river fragmentation problem by generating scenario simulations that help the managers to know the possible evolution of the fluvial network once some of its parameters have been modified, so that restoration measures can be planned and developed as appropriate as possible (Chapter II). 


\section{The importance of considering the balance of ecosystem services to measure the effects of dam removal to develop restoration management plans at basin scale.}

The lifespan of many of the dams that were built in our country during the 1970s, period considered as the "dam golden era" (García de Leániz 2008), is nearing its end. This means that some of them may be in the process of renewing their use licenses, which may lead to their decommission in case they lose the function for which they were created. This situation generates an opportunity to open a debate among several sectors (social, economic and environmental) about the need to implement an active policy of removing the excess of transversal barriers in the Spanish rivers.

In many cases, the net balance of the dam effects is the criterion to decide whether a dam is re-licensed or not. This balance is usually made taking into account exclusively economic parameters. However it is also essential to consider ecological and social aspects (Wegner and Pascual, 2011) because river networks represent systems that integrate social, economic and environmental elements, and the benefits and impacts of dams affect to different aspects of such complex systems. Consequently I used ecosystem services (ES), which provide a framework to address these challenges by integrating ecological and social values (Chan et al., 2006; Nelson et al., 2009; Trabucchi et al., 2012; Comín et al., 2018).

The problem of river fragmentation in the Spanish basins could reach a worrisome level when the great number of obstacles present in their rivers becomes evident. The Duero River Basin has a large number of barriers of all kinds, purposes and conservation states: from small abandoned obstacles that were old mills to large supply or hydroelectric dams that generate important services for human development. The classification of these barriers in groups of similar characteristics based on physical criteria (height of the dam), structural (typology of construction materials) and environmental (barrier passability for fish communities) helps to implement more realistic dam management strategies (Poff and Hart, 2002) by allowing to identify the groups of barriers that generate the greatest impact on fluvial systems in terms of ecosystem services. This approach can then be more easily extrapolated to other regions if dams are classified in the same way.

Once I made the classification of all the obstacles in the entire basin, I applied a method based on the FCMs to simulate scenarios. Simulations of the pre- and postremoval are made in order to compare their effect on the variable's weights so as to 
quantify this change and translate it into an improvement or worsening of the quality of ES and how this can affect human needs. Thus I prioritized which groups of dams are the most advisable to manage based on their contribution to the gain/loss ecosystem services balance. By conducting interviews with several experts on fluvial issues, a correlation matrix with the information provided was developed to feed the fuzzy method (Chapter III).

To finish, it is not the intention of this thesis to theorize about the definitions or the implications of a complex concept like ecosystem services are (which would give for another exclusive thesis on this matter), we just use a widely recognized concept to simulate possible scenarios of dam removal based on appropriate variables that can be used in similar studies in other areas.

\section{Literature cited}

Axelrod R. 1976. Structure of Decision: the Cognitive Maps of Political Elites, Princeton, NJ, USA, Princeton University Press.

Babbitt B. 2002. What goes up, may come down: Learning from our experiences with dam construction in the past can guide and improve dam removal in the future. BioScience, 52(8), 656-658.

Barnes JA, Harary F. 1983. Graph theory in network analysis. Social networks, 5(2), 235-244.

Bass, S. 2006. Environment for the MDGS: an IIED briefing. London: IIED.

Bednarek AT. 2001. Undamming rivers: a review of the ecological impacts of dam removal. Environmental management, 27(6), 803-814.

Bejarano MD, González del Tánago M, García de Jalón DG, Marchamalo M, SordoWard Á, Solana-Gutiérrez J. 2012. Responses of riparian guilds to flow alterations in a Mediterranean stream. Journal of Vegetation Science, 23(3), 443-458.

Bennett EM, Peterson GD, Gordon LJ. 2009. Understanding relationships among multiple ecosystem services. Ecology letters, 12 (12), 1394-1404.

Birnie-Gauvin K, Candee MM, Baktoft H, Larsen MH, Koed A, Aarestrup K. 2018. River connectivity reestablished: Effects and implications of six weir removals on brown trout smolt migration. River research and applications, 34(6), 548-554.

Bodin Ö. 2009. Ecological topology and networks. Meyers, S. (Ed.), Encyclopedia of Complexity and System Science. Springer, New York, pp. 2728-2744 
Bodin Ö, Saura S. 2010. Ranking individual patches as connectivity providers: integrating network analysis and patch removal experiments. Ecological Modelling 221:2393-2405.

Bourne CM, Kehler DG, Wiersma YF, Cote D. 2011. Barriers to fish passage and barriers to fish passage assessments: the impact of assessment methods and assumptions on barrier identification and quantification of watershed connectivity. Aquat Ecol 45: 389-403.

Branco P, Segurado P, Santos JM, Pinheiro P, Ferreirs MT. 2012. Does longitudinal connectivity loss affect the distribution of freshwater fish? Ecol Eng 48:70-78

Branco P. 2013. Improving connectivity for river fish. PhD Thesis, Instituto Superior de Agronomia, Universidade de Lisboa, Portugal.

Branco P, Segurado P, Santos JM, Ferreira MT. 2014. Prioritizing barrier removal to improve functional connectivity of rivers. Journal of Applied Ecology, 51(5), 1197-1206.

Brauman KA, Daily GC, Duarte TKE, Mooney HA. 2007. The nature and value of ecosystem services: an overview highlighting hydrologic services. Annu. Rev. Environ. Resour., 32, 67-98.

Brooks CP. 2006. Quantifying population substructure: extending the graph-theoretic approach. Ecology, 87, 864-872.

Bunn AG, Urban DL, Keitt TH. 2000. Landscape connectivity: a conservation application of graph theory. Journal of environmental management, 59(4), 265-278.

Bunn SE, Arthington AH. 2002. Basic principles and ecological consequences of altered flow regimes for aquatic biodiversity. Environmental management, 30(4), 492507.

Bunt CM, Castro-Santos T, Haro A. 2012. Performance of fish passage structures at upstream barriers to migration. River Research and Applications, 28(4), 457478.

Calabrese JM, Fagan WF. 2004. A comparison shoppers' guide to connectivity metrics: trading of between data requirement and information content. Front Ecol Environ 2:529-536

Calles O, Greenberg L. 2009. Connectivity is a two-way street-the need for a holistic approach to fish passage problems in regulated rivers. River Research and Applications, 25(10), 1268-1286.

Carranza ML, D'Alessandro E, Saura S, Loy A. 2012. Connectivity providers for semiaquatic vertebrates: the case of the endangered otter in Italy. Landscape Ecology 27: 281-290. 
Centro Ibérico de Restauración Fluvial (CIREF). 2017. An analysis of river fragmentation in the Spanish River Basins. Technical report developed by Ecohidráulica, S.L., Madrid, Spain. Available online in www.cirefluvial.com.

Chan KM, Shaw MR, Cameron DR, Underwood EC, Daily GC. 2006. Conservation planning for ecosystem services. PLoS biology, 4(11), e379.

Clavero M, Blanco-Garrido F, Prenda J. 2004. Fish fauna in Iberian Mediterranean river basins: biodiversity, introduced species and damming impacts. Aquatic Conservation: Marine and Freshwater Ecosystems, 14(6), 575-585.

Comín FA, Miranda B, Sorando R, Felipe-Lucia MR, Jiménez JJ, Navarro E. 2018. Prioritizing sites for ecological restoration based on ecosystem services. Journal of Applied Ecology, 55(3), 1155-1163.

Costanza R, de Groot R, Sutton P, Van der Ploeg S, Anderson SJ, Kubiszewski I, Farber S, Turner RK. 2014. Changes in the global value of ecosystem services. Global environmental change, 26, 152-158.

Cote D, Kehler DG, Bourne C, Wiersma YF. 2009. A new measure of longitudinal connectivity for stream networks. Landscape Ecol 24:101-113

Dadaser F, Özesmi U. 2002. Stakeholder analysis for Sultan Marshes ecosystem: a fuzzy cognitive approach for conservation of ecosystems. In: EPMR2002, Environmental Problems of the Mediterranean Region, Nicosia, North Cyprus, 12-15 April 2002.

Dale MRT, Fortin MJ (2010). From graphs to spatial graphs. Annual Review of Ecology, Evolution, and Systematics, 41.

De Groot RS, Alkemade R, Braat L, Hein L, Willemen L. 2010. Challenges in integrating the concept of ecosystem services and values in landscape planning, management and decision making. Ecological complexity, 7(3), 260-272.

Ern R, Huong DTT, Cong NV, Bayley M, Wang T. 2014. Effect of salinity on oxygen consumption in fishes: a review. Journal of Fish Biology, 84(4), 1210-1220.

Erös T, Schmera D, Schick RS. 2011. Network thinking in riverscape conservation - A graph-based approach. Biol Conserv 144:184-192

Erös T, Olden JD, Schick RS, Schmera D, Fortin MJ. 2012. Characterizing connectivity relationships in freshwaters using patch-based graphs. Landscape ecology, 27(2), 303-317.

Erös T, Grant, EHC. 2015. Unifying research on the fragmentation of terrestrial and aquatic habitats: patches, connectivity and the matrix in riverscapes. Freshwater Biology, 60(8), 1487-1501.

Eshuis J, Stuiver M. 2005. Learning in context through conflict and alignment: farmers and scientists in search of sustainable agriculture. Agric. Human Values 22(2), 137-148. 
Fausch KD, Torgersen CE, Baxter CV, Li HW. 2002. Landscapes to riverscapes: bridging the gap between research and conservation of stream fishes: a continuous view of the river is needed to understand how processes interacting among scales set the context for stream fishes and their habitat. BioScience, 52(6), 483-498.

Fausch KD, Rieman BE, Dunham JB, Young MK, Peterson DP. 2009. Invasion versus isolation: trade-offs in managing native salmonids with barriers to upstream movement. Conservation Biology, 23(4), 859-870.

Frissell CA, Liss WJ, Warren CE, Hurley MD. 1986. A hierarchical framework for stream habitat classification: viewing streams in a watershed context. Environmental management, 10(2), 199-214.

Fox CA, Magilligan F J, Sneddon CS. 2016. "You kill the dam, you are killing a part of me": Dam removal and the environmental politics of river restoration. Geoforum, 70, 93-104.

García de Jalón D, Sánchez Navarro R, Serrano J (Coords). 2007. Alteraciones de los regímenes de caudales de los ríos. Estrategia Nacional de Restauración de Ríos. Ministerio de Medio Ambiente. Universidad Politécnica de Madrid. Madrid.

García de Leániz C. 2008. Weir removal in salmonid streams: implications, challenges and practicalities. Hydrobiologia, 609(1), 83-96.

Gasith A, Resh VH. 1999. Streams in Mediterranean climate regions: abiotic influences and biotic responses to predictable seasonal events. Annual review of ecology and systematics, 30(1), 51-81.

Gibbons M, Limoges C, Nowotny H, Schwartzman S, Scott P, Trow M. 1994. The new production of knowledge: the dynamics of science and research in contemporary societies, London, Sage.

Gilvear DJ, Spray CJ, Casas-Mulet R. 2013. River rehabilitation for the delivery of multiple ecosystem services at the river network scale. Journal of environmental management, 126, 30-43.

Giordano R, Passarella G, Uricchio VF, Vurro M. 2005. Fuzzy cognitive maps for issue identification in a water resources conflict resolution system. Phys. Chem. Earth 30, 463-469.

González Fernández G, Pérez Cardenal D, Miguelez Carbajo D, Gallego García R, Fernández Suárez R, Álvarez Durango E, Canal Rubio P, Roa Álvarez I, Rosa Cubo E, Seisdedos Fidalgo P. 2010. Diagnóstico de la conectividad longitudinal en la Cuenca del Duero. Ministerio de Medio Ambiente, Medio Rural y Marino. Available in http://www.chduero.es/acciona5/metodologia/ic.pdf

Gopal B. 2016. A conceptual framework for environmental flows assessment based on ecosystem services and their economic valuation. Ecosystem Services, 21, 5358. 
Grant EHC. 2011. Structural complexity, movement bias, and metapopulation extinction risk in dendritic ecological networks. Journal of the North American Benthological Society, 30(1), 252-258.

Grantham TE, Figueroa R, Prat N. 2013. Water management in mediterranean river basins: a comparison of management frameworks, physical impacts, and ecological responses. Hydrobiologia, 719(1), 451-482.

Harary F, Norman RZ. 1953. Graph theory as a mathematical model in social science (p. 45). Ann Arbor: University of Michigan, Institute for Social Research.

Hart DD, Finelli CM. 1999. Physical-biological coupling in streams: the pervasive effects of flow on benthic organisms. Annual review of ecology and systematics, 30(1), 363-395.

Hart DD, Johnson TE, Bushaw-Newton KL, Horwitz RJ, Bednarek AT, Charles DF, Kreeger DA, Velinsky DJ. 2002. Dam removal: challenges and opportunities for ecological research and river restoration: we develop a risk assessment framework for understanding how potential responses to dam removal vary with dam and watershed characteristics, which can lead to more effective use of this restoration method. BioScience, 52(8), 669-682.

Helfgott A, Lord S, Bean N, Wildenberg M, Gray S, Gray S, Vervoort J, Kok K, Ingram J. 2015. Clarifying Fuzziness: Fuzzy Cognitive Maps, Neural Networks and System Dynamics Models in Participatory Social and Environmental Decision-aiding Processes. Global Environmental Change no. Submitted.

Hill NL, Trueman JR, Prévost AD, Fraser DJ, Ardren WR, Grant JW. 2019. Effect of dam removal on habitat use by spawning Atlantic salmon. Journal of Great Lakes Research, 45(2), 394-399.

Hilty JA, Lidicker Jr WZ, Merenlender AM. 2012. Corridor ecology: the science and practice of linking landscapes for biodiversity conservation. Island Press.

Hobbs BF, Ludsin SA, Knight RL, Ryan PA, Biberhofer J, Ciborowski JJH. 2002. Fuzzy cognitive mapping as a tool to define management objectives for complex ecosystems. Ecol. Appl. 12, 1548-1565.

Ibisate A, Ollero A, Ballarín D, Horacio J, Mora D, Mesanza A, Ferrer-boix C, Acín V, Granado D, Martín-Vide JP. 2016. Geomorphic monitoring and response to two dam removals: rivers Urumea and Leitzaran (Basque Country, Spain). Earth Surface Processes and Landforms, 41(15), 2239-2255.

Januchowski-Hartley SR, McIntyre PB, Diebel M, Doran PJ, Infante DM, Joseph C, Allan JD. 2013. Restoring aquatic ecosystem connectivity requires expanding inventories of both dams and road crossings. Front Ecol Environ. 11(4), 211-217

Jax K, Barton DN, Chan KM, De Groot R, Doyle U, Eser U, Görg C, Gómez-Baggethun E, Griewald $Y$, Haber $W$, Haines-Young $R$, Heink $U$, Jahn $T$, Joosten $H$, Kerschbaumer L, Korn H, Luck GW, Matzdorf B, Muraca B, Nesshöver C, Norton 
B, Ott K, Potschin M, Rauschmayer F, von Haaren C, Wichmann S. 2013. Ecosystem services and ethics. Ecological Economics, 93, 260-268.

Jetter AJ. 2006. Fuzzy cognitive maps for engineering and technology management: what works in practice? In Technology Management for the Global Future, 2006. PICMET 2006 (Vol. 2, pp. 498-512). IEEE.

Junk WJ, Bayley PB, Sparks RE. 1989. The flood pulse concept in river-floodplain systems. Canadian special publication of fisheries and aquatic sciences, 106(1), 110-127.

Keitt TH, Urban DL, Milne BT. 1997. Detecting critical scales in fragmented landscapes. Conservation ecology, 1(1).

Kemp PS, O'hanley JR. 2010. Procedures for evaluating and prioritising the removal of fish passage barriers: a synthesis. Fisheries Management and Ecology, 17(4), 297-322.

Kok K. 2009. The potential of Fuzzy Cognitive Maps for semi-quantitative scenario development, with an example from Brazil. Global Environmental Change 19, 122-133.

Kondolf GM, Boulton AJ, O'Daniel S, Poole GC, Rahel FJ, Stanley EH, Wohl E, Bång A, Carlstrom J, Cristoni C, Huber H, Koljonen S, Louhi P, Nakamura K. 2006. Process-based ecological river restoration: visualizing three-dimensional connectivity and dynamic vectors to recover lost linkages. Ecology \& society, 11(2), 1-16.

Kosko B. 1986. Fuzzy cognitive maps. International Journal of Man-Machine Studies 1, 65-75.

Kosko B. 1987. Adaptive inference in fuzzy knowledge networks. In: Proceedings of the First IEEE International Conference on Neural Networks (ICNN-86), San Diego, CA, pp. 261-268.

Kontogianni A, Papageorgiou E, Salomatina L, Skourtos M, Zanou B. 2012. Risks for the Black Sea marine environment as perceived by Ukrainian stakeholders: A fuzzy cognitive mapping application. Ocean \& coastal management, 62, 34-42.

Larinier M. 2001. Environmental issues, dams and fish migration. FAO fisheries technical paper, 419, 45-89.

Liou SM, Lo SL, Hu CY. 2003. Application of two-stage fuzzy set theory to river quality evaluation in Taiwan. Water Research, 37(6), 1406-1416.

Lorenz S, Martinez-Fernández V, Alonso C, Mosselman E, García de Jalón D, González del Tánago M, Belletti B, Hendriks D, Wolter C. 2015. Fuzzy cognitive mapping for predicting hydromorphological responses to multiple pressures in rivers. Journal of Applied Ecology. 53(2), 559-566. 
Lucas MC, Baras E, Thom TJ, Duncan A, Slavík O 2001. Migration of freshwater fishes (Vol. 47). Oxford: Blackwell Science.

Lucas MC, Bubb DH, Jang MH, Ha K, Masters JE. 2009. Availability of and access to critical habitats in regulated rivers: effects of low-head barriers on threatened lampreys. Freshwater Biology, 54(3), 621-634.

Malek Z. 2017. Fuzzy-Logic Cognitive Mapping: Introduction and Overview of the Method. In: Environmental Modeling with Stakeholders, Theory, Methods and Applications. S. Gray, M. Paolisso, R. Jordan, S. Gray (Eds.) (chapter 7, pp127143)

Markinos A, Papageorgiou E, Stylios C, Gemtos T. 2007. Introducing Fuzzy Cognitive Maps for decision making in precision agriculture. Precision agriculture, 7, 223.

Mendoza GA, Prabhu R. 2003. Qualitative multi-criteria approaches to assessing indicators of sustainable forest resource management. For. Ecol. Manage. 174, 329-343.

Millennium Ecosystem Assessment. 2003. Millennium Ecosystem Assessment (MA): Strengthening Capacity to Manage Ecosystems Sustainably for Human WellBeing. Published by World Resources Institute, Washington, DC.

Millennium Ecosystem Assessment. 2005. Millennium Ecosystem Assessment. Ecosystems and Human Well-Being: Biodiversity Synthesis, Published by World Resources Institute, Washington, DC.

Ministry of Agriculture and Fishing, Food and Environment (MAPAMA). 2016. Sistema Nacional de Cartografía de Zonas Inundables - Inventario de Presas y Embalses (SNCZI-IPE). http://sig.mapama.es/snczi/

Ministerio de Obras Públicas y Urbanismo (MOPU). 1986. Inventario de presas españolas. Dirección General de Obras Hidráulicas.

$\begin{array}{llllll}\text { Ministerio para la Transición } & \text { Ecológica } & \text { (MITECO). }\end{array}$ http://sig.magrama.es/snczi/visor.html?herramienta=Presas

Minor ES, Urban, DL. 2007. Graph theory as a proxy for spatially explicit population models in conservation planning. Ecol. Appl. 17:1771-1782.

Minor ES, Urban DL. 2008. A graph-theory framework for evaluating landscape connectivity and conservation planning. Conserv. Biol. 22:297-307.

Mitchell MG, Bennett EM, Gonzalez A. 2013. Linking landscape connectivity and ecosystem service provision: current knowledge and research gaps. Ecosystems, 16(5), 894-908.

Mooney HA, Ehrlich PR, Daily GE. 1997. Ecosystem services: a fragmentary history. Nature's Services: societal dependence on natural ecosystems, 11-19.

Morán-Tejeda E, Ceballos-Barbancho A, Llorente-Pinto JM. 2010. Hydrological response of Mediterranean headwaters to climate oscillations and land-cover 
changes: The mountains of Duero River basin (Central Spain). Global and Planetary Change, 72(1-2), 39-49.

Mouratiadou I, Moran D. 2007. Mapping public participation in the Water Framework Directive: A case study of the Pinios River Basin, Greece. Ecol. Econ. 62, 66-76.

Nelson E, Mendoza G, Regetz J, Polasky S, Tallis H, Cameron D, Chan KM, Daily GC, Goldstein J, Kareiva PM, Lonsdorf E, Naidoo R, Ricketts TH, Shaw MR. 2009. Modeling multiple ecosystem services, biodiversity conservation, commodity production, and tradeoffs at landscape scales. Frontiers in Ecology and the Environment, 7(1), 4-11.

Nicola GG, Elvira B, Almodovar A. 1996. Dams and fish passage facilities in the large rivers of Spain: effects on migratory species. Large Rivers 10:375-379

Nilsson C, Reidy CA, Dynesius M, Revenga C. 2005. Fragmentation and flow regulation of the world's large river systems. Science, 308(5720), 405-408.

Özesmi U, Özesmi S. 2001. A participatory approach to ecosystem conservation: Uluabat Lake environmental management plan using fuzzy cognitive maps and stakeholder analysis. In Proceedings of the IV National Environmental Engineering Congress, Mersin, Turkey (pp. 7-10).

Özesmi U, Özesmi S. 2003. A participatory approach to ecosystem conservation: fuzzy cognitive maps and stakeholder group analysis in Uluabat Lake, Turkey. Environmental management, 31(4), 0518-0531.

Özesmi U, Özesmi SL. 2004. Ecological Models based on People's Knowledge: A MultiStep Fuzzy Cognitive Mapping Approach. Ecological Modelling. 176, 43-64.

Padgham M, Webb JA. 2010. Multiple structural modifications to dendritic ecological networks produce simple responses. Ecological Modelling, 221(21), 2537-2545.

Paolisso M, Trombley J. 2017. Cognitive, Material and Technological Considerations in Participatory Environmental Modeling. In: Environmental Modeling with Stakeholders, Theory, Methods and Applications. S. Gray, M. Paolisso, R. Jordan, S. Gray (Eds.) (chapter 1, pp3-23)

Papageorgiou E, Stylios CD, Groumpos PP. 2003. An integrated two-level hierarchical system for decision making in radiation therapy based on fuzzy cognitive maps. Biomedical Engineering, IEEE Transactions on, 50(12), 1326-1339.

Papageorgiou El, Markinos A, Gemtos T. 2009. Application of fuzzy cognitive maps for cotton yield management in precision farming. Expert Syst. Appl. 36 (10), 12399-12413.

Papageorgiou El, Kontogianni A. 2012. Using Fuzzy Cognitive Mapping in Environmental Decision Making and Management: A Methodological Primer and an Application, International Perspectives on Global Environmental Change. Dr. Stephen Young (Ed.), InTech 
Pascual-Hortal L, Saura S. 2006. Comparison and development of new graph-based landscape connectivity indices: towards the priorization of habitat patches and corridors for conservation. Landscape Ecol. 21:959-967.

Peterson GD, Beard Jr TD, Beisner BE, Bennett EM, Carpenter SR, Cumming GS, Dent $\mathrm{CL}$, Havlicek TD. 2003. Assessing future ecosystem services: a case study of the Northern Highlands Lake District, Wisconsin. Conservation Ecology, 7(3).

Pejchar L, Warner K. 2001. A river might run through it again: criteria for consideration of dam removal and interim lessons from California. Environmental management, 28(5), 561-575.

Pringle C. 2003. What is hydrologic connectivity and why is it ecologically important?. Hydrological Processes, 17(13), 2685-2689.

Poeppl RE, Coulthard T, Keesstra SD, Keiler M. 2019. Modeling the impact of dam removal on channel evolution and sediment delivery in a multiple dam setting. International Journal of Sediment Research.

Poff NL, Allan JD, Bain MB, Karr JR, Prestegaard KL, Richter BD, Sparks RE, Stromberg JC. 1997. The natural flow regime. BioScience, 47(11), 769-784.

Poff NL, Hart DD. 2002. How Dams Vary and Why It Matters for the Emerging Science of Dam Removal. American Institute of Bio Sciences Bulletin, 52(8), 659-668.

Power ME, Parker G, Dietrich WE, Sun A. 1995. How does floodplain width affect floodplain river ecology? A preliminary exploration using simulations. Geomorphology, 13(1-4), 301-317.

Radinger J, Wolter C. 2014. Patterns and predictors of fish dispersal in rivers. Fish and fisheries, 15(3), 456-473.

Radomski PJ, Goeman TJ. 1996. Decision making and modeling in freshwater sportfisheries management. Fisheries 21, 14-21.

Ramankutty N, Evan AT, Monfreda C, Foley JA. 2008. Farming the planet: 1. Geographic distribution of global agricultural lands in the year 2000. Global biogeochemical cycles, 22(1).

Rinaudo JD, Garin P. 2005. The benefits of combining lay and expert input for watermanagement planning at the watershed level. Water Policy 7(3), 279-294

Rincón G, Solana-Gutiérrez J, Alonso C, Saura S, García de Jalón D. 2017. Longitudinal connectivity loss in a riverine network: accounting for the likelihood of upstream and downstream movement across dams. Aquatic sciences, 79(3), 573-585.

Rincón G, Alonso C, González G, Solana-Gutiérrez J. In prep. How much is gained from dam removal? An ecosystem services balance approach based on Fuzzy Cognitive Maps. 
Rivers-Moore N, Mantel S, Ramulifo P, Dallas H. 2016. A disconnectivity index for improving choices in managing protected areas for rivers. Aquatic Conservation: Marine and Freshwater Ecosystems, 26(S1), 29-38.

Rodeles AA, Galicia D, Miranda R. 2017. Recommendations for monitoring freshwater fishes in river restoration plans: A wasted opportunity for assessing impact. Aquatic Conservation: Marine and Freshwater Ecosystems, 27(4), 880-885.

Rodríguez JP, Beard Jr TD, Bennett EM, Cumming GS, Cork SJ, Agard J, Dobson AP, Peterson GD. 2006. Trade-offs across space, time, and ecosystem services. Ecology and society, 11(1).

Rodríguez-Lozano P, Rieradevall M, Prat N. 2016. Top predator absence enhances leaf breakdown in an intermittent stream. Science of the Total Environment, 572, 1123-1131.

Santucci Jr VJ, Gephard SR, Pescitelli SM. 2005. Effects of multiple low-head dams on fish, macroinvertebrates, habitat, and water quality in the Fox River, Illinois. North American Journal of Fisheries Management, 25(3), 975-992.

Saura S, Pascual-Hortal L. 2007. A new habitat availability index to integrate connectivity in landscape conservation planning: comparison with existing indices and application to a case study. Landscape Urban Plan 83:91-103

Saura S, Rubio L. 2010. A common currency for the different ways in which patches and links can contribute to habitat availability and connectivity in the landscape. Ecography 33:523-537

Saura S, Torné J. 2009. Conefor Sensinode 2.2: a software package for quantifying the importance of habitat patches for landscape connectivity. Environmental Modelling \& Software 24: 135-139.

Schick RS, Lindley ST. 2007. Directed connectivity among fish populations in a riverine network. J Appl Ecol 44: 1116-1126

Segurado P, Branco P, Ferreira MT. 2013. Prioritizing restoration of structural connectivity in rivers: a graph based approach. Landscape Ecol 28:1231-1238.

Segurado P, Branco P, Avelar AP, Ferreira MT. 2014. Historical changes in the functional connectivity of river based on spatial networks analysis and the past occurrences of diadromous species in Portugal. Aquatic Sciences.

Silva AT, Lucas MC, Castro-Santos T, Katopodis C, Baumgartner LJ, Thiem JD, Aarestrup K, Pompeu PS, O'Brien GC, Braun DC, Burnett NJ, Zhu DZ, Fjeldstad HP, Forseth T, Rajaratnam N, Williams JG, Cooke ST. 2017. The future of fish passage science, engineering, and practice. Fish and Fisheries, 1-23.

Silvert W. 1997. Ecological impact classification with fuzzy sets. Ecological Modelling 96. 1-10. 
Silvert W. 2000. Fuzzy indices of environmental conditions. Ecological Modelling 130. 111-119.

Skov F, Svenning JC. 2003. Predicting plant species richness in a managed forest. For. Ecol. Manage. 6200, 1-11.

Solana-Gutiérrez J, Rincón G, Alonso C, García de Jalón D. 2017. Using fuzzy cognitive maps for predicting river management responses: A case study of the Esla River basin, Spain. Ecological Modelling, 360, 260-269.

Stanley EH, Doyle MW. 2002. A geomorphic perspective on nutrient retention following dam removal: Geomorphic models provide a means of predicting ecosystem responses to dam removal. BioScience, 52(8), 693-701.

Stylios CD, Groumpos PP. 2004. Modeling complex systems using fuzzy cognitive maps. IEEE Transactions on Systems, Man, and Cybernetics-Part A: Systems and Humans, 34(1), 155-162.

Stylios, CD, Georgopoulos, VC, Malandraki, GA, Chouliara S. 2008. Fuzzy cognitive map architectures for medical decision support systems. Applied Soft Computing, 8(3), 1243-1251.

Tan CO, Özesmi U. 2006. A generic shallow lake ecosystem model based on collective expert knowledge. Hydrobiologia, 563(1), 125-142.

Thorp JH, Delong MD. 1994. The riverine productivity model: an heuristic view of carbon sources and organic processing in large river ecosystems. Oikos, 305308.

Trabucchi M, Ntshotsho P, O'Farrell P, Comín FA. 2012. Ecosystem service trends in basin-scale restoration initiatives: a review. Journal of Environmental Management, 111, 18-23.

Tockner K, Schiemer F, Ward JV. 1998. Conservation by restoration: the management concept for a river-floodplain system on the Danube River in Austria. Aquat Conserv 8:71-86

Ulrich W. 1993. Some Difficulties of Ecological Thinking, Considered From a Critical Systems Perspective: A Plea for Critical Holism. Systems Practice, 6, 583-611.

Urban D, Keitt T. 2001. Landscape connectivity: a graph-theoretic perspective. Ecology, 82(5), 1205-1218.

Vannote RL, Minshall GW, Cummins KW, Sedell JR, Cushing CE. 1980. The river continuum concept. Canadian journal of fisheries and aquatic sciences, 37(1), 130-137.

Vasslides JM, Jensen OP. 2016. Fuzzy cognitive mapping in support of integrated ecosystem assessments: Developing a shared conceptual model among stakeholders. Journal of environmental management, 166, 348-356. 
Vidal-Abarca MR, Suárez ML. 2013. Which are, what is their status and what can we expect from ecosystem services provided by Spanish rivers and riparian areas? Biodiversity and conservation, 22(11), 2469-2503.

van Vliet M, Flörke M, Varela-Ortega C, Çakmak EH, Khadra R, Esteve P, D'Agostino D, Dudu H, Bärlund I, Kok K, 2017. FCMs as a common base for linking participatory products and models. In: Gray S, Paolisso M, Jordan R, Gray S. (Eds.), Environmental Modeling with Stakeholders, Theory, Methods and Applications, pp. 145-170 (chapter 8).

Ward JV. 1989. The four-dimensional nature of the lotic ecosystem. Journal of the North American Benthological Society 8:2-8

Ward JV, Stanford JA. 1995. Ecological connectivity in alluvial river ecosystems and its disruption by flow regulation. Regulated rivers: research \& management, 11(1), 105-119.

Wegner G, Pascual U. 2011. Cost-benefit analysis in the context of ecosystem services for human well-being: A multidisciplinary critique. Global Environmental Change, 21(2), 492-504.

Wiens JA. 2002. Riverine landscapes: taking landscape ecology into the water. Freshwater biology, 47(4), 501-515.

Wildenberg M, Bachhofer M, Isak KG, Skov F. 2014. Use and evaluation of FCM as a tool for long term socio ecological research. In Fuzzy cognitive maps for applied sciences and engineering (pp. 221-236). Springer Berlin Heidelberg.

Wipfli MS, Gregovich DP. 2002. Export of invertebrates and detritus from fishless headwater streams in southeastern Alaska: implications for downstream salmonid production. Freshwater Biology, 47(5), 957-969.

Wohl E, Polvi LE, Cadol D. 2011. Wood distribution along streams draining old-growth floodplain forests in Congaree National Park, South Carolina, USA. Geomorphology, 126(1-2), 108-120.

Wohl E, Beckman ND. 2014. Leaky rivers: implications of the loss of longitudinal fluvial disconnectivity in headwater streams. Geomorphology, 205, 27-35.

Yaman D, Polat S. 2009. A fuzzy cognitive map approach for effect-based operations: An illustrative case. Information Sciences, 179(4), 382-403.

Zarfl C, Lumsdon AE, Berlekamp J, Tydecks L, Tockner K. 2015. A global boom in hydropower dam construction. Aquatic Sciences, 77(1), 161-170. 


\section{PART 2. METHODOLOGY}

"Lo que importa no es qué pequeño pueda ser el comienzo: lo que se hace una vez bien, se hace para siempre"

H.D. Thoreau 
To develop this research, a variety of methodological approaches has been applied, which includes data management, preprocessing, modelling and simulation techniques. A general overview of the methods is provided in the following sections, which are completed in the methodological sections of the each result chapters. The main methodology section of this thesis is structured into three different sections.

\section{Section 1: Location and geographical context}

The research of this thesis was carried out in the Duero River Basin (NW Spain), although the studies were focused on objects (sub-basins) of different sizes and scopes. Three different approaches were applied, the first study (Chapter I) dealt with a medium-sized basin in which the river has been modeled as a graph to measure the loss of connectivity generated by the barriers located in its river segments. The second study (Chapter II) was applied in a larger basin subjected to several anthropogenic impacts. Finally, the third study (Chapter III) was applied on the whole Duero basin with the aim of implementing both scopes, in order to generate a management plan for the inventoried barriers based on several structural parameters when remove some group of barriers according to the gain and loss ecosystem services balance (Figure 1).

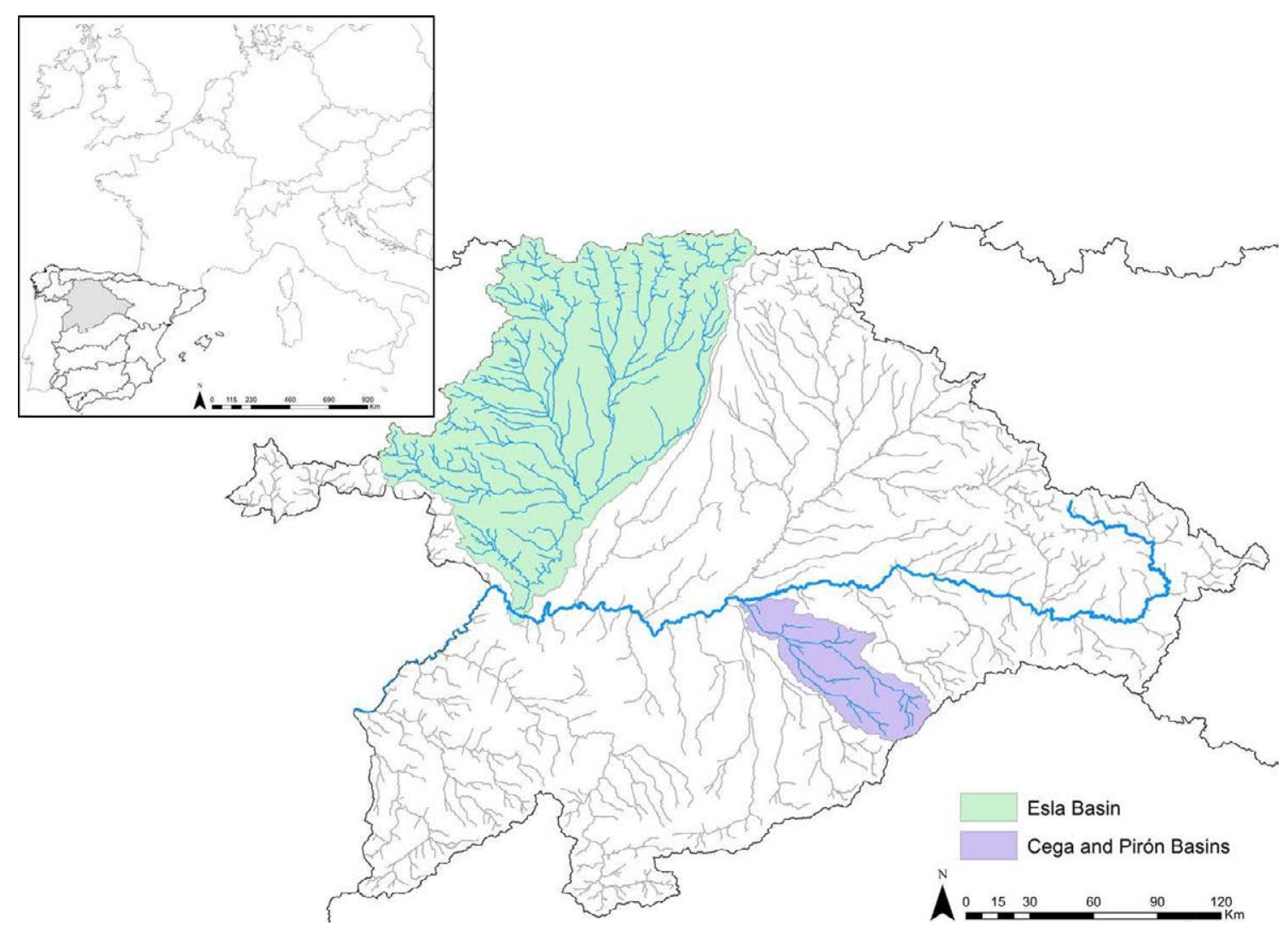

Figure 1. General location of the study area including the Cega and Esla sub-basins, with the Duero River as the central axis of the basin. 
The Duero River Basin is a transboundary system which comprises a territory of 98073 $\mathrm{km}^{2}$, of which $80 \%\left(78859 \mathrm{~km}^{2}\right.$ ) corresponds to Spain and the rest to Portugal (CHD 2019). Represents one of the most important hydrological systems of the Iberian Peninsula (Morán-Tejeda et al., 2010). Most of the basin area corresponds to a topographic depression filled with Tertiary and Quaternary sediments, configuring a high plateau with an average height above 700 m.a.s.l approximately and surrounded by mountain systems in almost its entirety (Morán-Tejeda et al., 2010). The predominant climate is continental Mediterranean with an average rainfall of 612 $\mathrm{mm} /$ year, which generates about $15000 \mathrm{hm}^{3}$ of total runoff (Paredes-Arquiola et al., 2011).

Agricultural use is the main economic activity of the basin, including unirrigated (3.5 million ha) and irrigated ( 0.5 million ha) crops. Irrigation is therefore the largest water consumer activity in the entire basin, consuming $80 \%$ (3600 million $\mathrm{m}^{3} /$ year) of the total volume of water consumed (Paredes-Arquiola et al., 2011).

The hydropower production also means an important use of water resources. One of the main problems that have occurred since the last decades is the continuous decline of the population in the basin and its concentration in small urban centers. Despite this, the demand for water for urban use is low (CHD 2019, Paredes-Arquiola et al., 2011).

The Cega and Pirón River Basins.

The river Cega and its main tributary the Pirón River constitute a medium-sized river basin located in the north west of the Iberian Peninsula. The Cega River is a tributary of the Duero River on its left bank. The Cega River has a total length of $149 \mathrm{~km}$, drains an area of $2579 \mathrm{~km}^{2}$ and flows mainly from south to north presenting an average total annual discharge of $232.1 \mathrm{hm}^{3}$, while its main tributary, the Pirón River, has a length of $98 \mathrm{~km}$, a basin area of $1024 \mathrm{~km}^{2}$ and an average annual discharge of $74 \mathrm{hm}^{3}$ (CHD 2009). Both are small Mediterranean rivers with a pluvio-nival hydrological regime, presenting severe droughts in the summer.

Basin headwaters are dominated by a granitic meta-dendritic geology composition. In the piedemont zone, a karst belt is located giving way to large sand flatlands of detritic-tertiary origin with detritic-quaternary alluvial deposits (Santiago et al., 2016). 
The flow regime in the Cega River is not regulated, despite the presence of numerous barriers of different size in its channel. However, the Pirón River is regulated by the presence of Torrecaballeros dam in its headwaters (height $26 \mathrm{~m}$; capacity $0.324 \mathrm{hm}^{3}$; altitude 1390 m.a.s.l.).

\section{The Esla River Basin}

The Esla River is a tributary of Duero River on its right side, located in the northwestern part of the Duero Basin. The main axis of the river Esla has a length of $\mathbf{2 8 7 . 8 3}$ $\mathrm{km}$, a basin area of $16026 \mathrm{~km} 2$ which includes its main tributaries, and an average contribution of $5265 \mathrm{hm}^{3} /$ year. The main rivers of the basin flow with a north-south component (Martínez-Fernández 2018).

The Esla River is regulated by the presence of two large reservoirs: Ricobayo dam and Riaño dam. The Ricobayo dam, whose operation began in 1935, is placed near the junction of the Esla River with the Duero River, has a maximum capacity of $1179 \mathrm{hm}^{3}$ and covers an area of $159.52 \mathrm{~km}^{2}$ (CHD 2019). The Riaño dam is located on the river source and was built in 1998. It covers an area of $817.51 \mathrm{~km}^{2}$ with a maximum water storage capacity of $651 \mathrm{hm}^{3}$ (CHD 2019), which supposes nearly 90\% of the natural runoff (Martínez-Fernández 2018). In addition, there are also reservoirs in some of the tributaries which condition the water regime of the basin, changing the natural pattern of the regulated rivers with an increase of water availability in summer, coinciding with the irrigation session. The presence of the Alto de Payuelos, Cea-Carrión, CurueñoPorma and Páramo Bajo channels plays an important role in the Esla River basin regulation (CHD 2019).

The basin fluvial system supplies water to a total of 278000 people, including the city of León; to an irrigation area of 97000 ha; to three fish farms; and to the refrigeration system of the Robla thermal power plant. In addition, 19 hydroelectric plants are present, with a combined capacity of $451 \mathrm{MW}$ and an average production of 1115 GWh. A marked increase of irrigation demand is expected (CHD 2019). In the basin there are also natural areas of great ecological value, many of them associated with rivers. 


\section{MATERIAL AND METHODS}

\section{Section 2: Data collection (information used to develop the research)}

\section{Subsection 1: Inventory of fish communities}

In order to measure the effect that barriers are generating on the habitat of fish species, it is essential to know the existing fish communities in the studied river reaches.

\section{Cega and Piron Rivers fish communities}

Electrofishing samplings studies conducted in August of two consecutive years (1997 and 1998) have been used to characterize fish populations (Estudios Territoriales Integrados 1997, Estudios Biológicos 1998). A total of 37 sampling stations have been analyzed, 25 for the Cega River ( $C 1$ to C25 sites from $1610 \mathrm{~m}$ to $730 \mathrm{~m}$ ) and 12 for the Pirón River (P1 to P12 sites from $1620 \mathrm{~m}$ to $786 \mathrm{~m}$ ). More detailed information can be seen in figure 2 and in table 1.

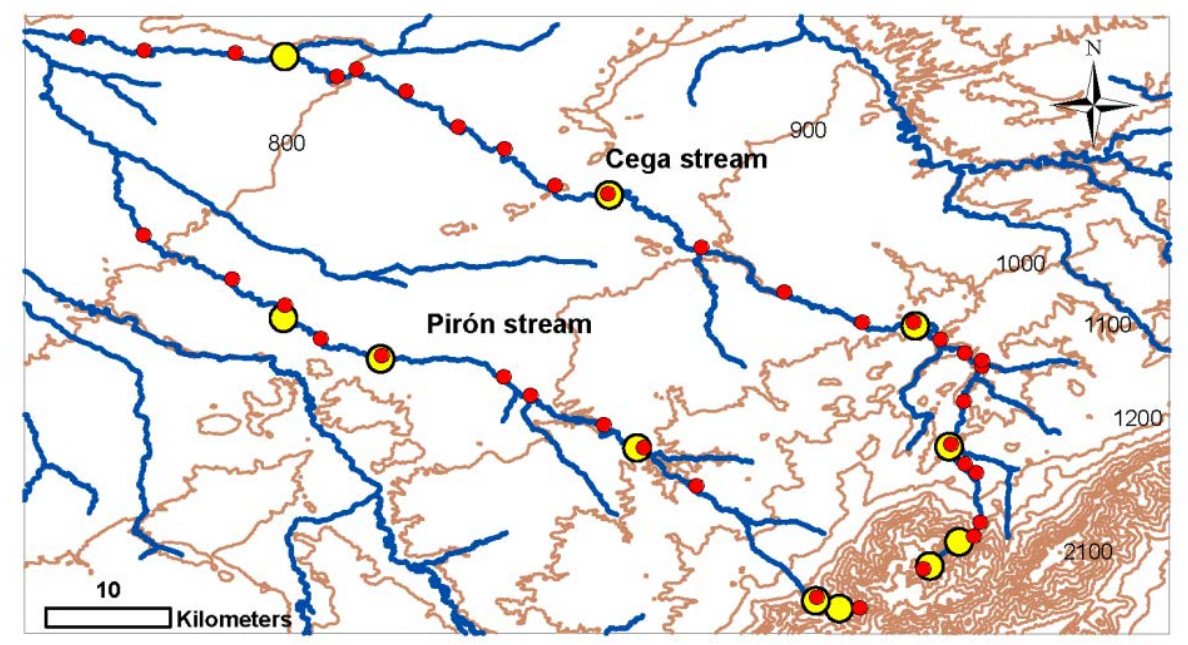

Figure 2. Location map of electrofishing sites (red circles). Blue lines: main drainage network. Electrofishing sites are numbered from headwaters to downwaters, C1 to C25 (Cega stream) and P1 to P12 (Pirón stream). Distance between contour lines (altitude above sea level): 100 meters. The figure also includes the location of thermographs (yellow circles) used to measure water temperatures (from Santiago et al., 2016).

In the basin of the rivers Cega and Pirón have been found the following fish species: Brown trout (Salmo trutta), Bermejuela (Achondrostoma arcasii), Northern Iberian chub (Squalius carolitertii), Northern Iberian spined-loach (Cobitis calderoni), Pyrenean gudgeon (Gobio lozanoi), Tench (Tinca tinca) and Bermejuela x Northern straightmouth nase (Achondrostoma arcasii $x$ Pseudochondrostoma duriense). 
Table 1. Altitude of electrofishing sites at Cega stream and Pirón stream. Units: meters above sea level (from Santiago et al., 2016).

\begin{tabular}{cccc|cc}
\hline \multicolumn{4}{c|}{ Cega river } & \multicolumn{2}{c}{ Pirón river } \\
\hline Site & Altitude & Site & Altitude & Site & Altitude \\
C1 & 1610 & C14 & 898 & P1 & 1620 \\
C2 & 1320 & C15 & 885 & P2 & 1337 \\
C3 & 1258 & C16 & 866 & P3 & 969 \\
C4 & 1150 & C17 & 845 & P4 & 908 \\
C5 & 1106 & C18 & 805 & P5 & 879 \\
C6 & 1044 & C19 & 798 & P6 & 858 \\
C7 & 995 & C20 & 788 & P7 & 856 \\
C8 & 966 & C21 & 780 & P8 & 835 \\
C9 & 961 & C22 & 778 & P9 & 822 \\
C10 & 944 & C23 & 762 & P10 & 810 \\
C11 & 934 & C24 & 748 & P11 & 804 \\
C12 & 921 & C25 & 730 & P12 & 786 \\
C13 & 910 & & & & \\
\hline
\end{tabular}

Both rivers have the same distribution of fish species except Iberian barbel (Luciobarbus bocagei) that only appears in the Cega River, while Common carp (Cyprinus carpio) is found only in Pirón River.

The trout was recorded almost in the entire Cega, reaching higher densities in the upper reaches. It is followed in density by northern Iberian chub and bermejuela. The following species are gudgeon and barbel. The Northern Iberian spined-loach, tench and common carp were caught occasionally. Table 2 shows results at Cega River.

Table 2. Estimated density by electrofishing (ind $/ 100 \mathrm{~m}^{2}$ ) in August 1998 at Cega stream.

\begin{tabular}{ccccccccc}
\hline Station & S.trutta & S.carolitertii & A.arcasii & Hybrids & G.lozanoi & L.bocagei & C.calderoni & T.tinca \\
\hline C1 & 13,144 & 0,000 & 0,000 & 0,000 & 0,000 & 0,000 & 0,000 & 0,000 \\
C2 & 38,969 & 0,000 & 0,000 & 0,000 & 0,000 & 0,000 & 0,000 & 0,000 \\
C3 & 30,482 & 0,000 & 0,000 & 0,000 & 0,000 & 0,000 & 0,000 & 0,000 \\
C4 & 28,275 & 0,765 & 0,000 & 0,000 & 0,000 & 0,000 & 0,000 & 0,000 \\
C5 & 42,400 & 0,200 & 0,400 & 0,000 & 0,000 & 0,000 & 0,000 & 0,000 \\
C6 & 7,959 & 25,291 & 9,207 & 0,000 & 0,000 & 0,000 & 0,670 & 0,000 \\
C8 & 12,003 & 8,599 & 32,421 & 0,000 & 0,000 & 0,000 & 0,169 & 0,000 \\
C10 & 7,565 & 2,743 & 27,875 & 0,000 & 23,099 & 0,358 & 0,090 & 0,000 \\
C12 & 16,531 & 15,381 & 28,111 & 0,000 & 18,516 & 0,000 & 0,000 & 0,000 \\
C13 & 3,663 & 5,275 & 4,396 & 0,000 & 0,000 & 0,000 & 0,000 & 0,000 \\
C15 & 0,282 & 1,972 & 7,042 & 8,169 & 0,000 & 0,000 & 0,000 & 0,000 \\
C16 & 5,797 & 0,235 & 22,771 & 0,000 & 9,958 & 0,000 & 0,000 & 0,000 \\
C17 & 5,098 & 0,127 & 1,601 & 0,254 & 7,467 & 0,000 & 0,000 & 0,000 \\
C18 & 1,429 & 1,000 & 1,143 & 0,000 & 0,000 & 0,000 & 0,000 & 0,000 \\
C19 & 0,714 & 0,238 & 1,429 & 0,000 & 0,000 & 0,000 & 0,000 & 0,000 \\
C20 & 1,895 & 0,292 & 1,458 & 0,000 & 0,000 & 0,146 & 0,000 & 0,000
\end{tabular}




\begin{tabular}{lllllllll} 
C21 & 1,746 & 0,159 & 0,952 & 0,000 & 0,000 & 0,476 & 0,000 & 0,000 \\
C24 & 1,111 & 3,148 & 7,407 & 0,556 & 0,000 & 1,296 & 0,000 & 0,185 \\
\hline
\end{tabular}

The species distribution pattern is very similar in both rivers. For Cega River is (from headwaters to downwaters): trout- chub /bermejuela- spined-loach- barbel /gudgeon, while for Pirón River is trout- bermejuela/chub- spined-loach/gudgeon-carp.

\section{Subsection 2: Duero River Basin barriers inventory}

The most evident and determinant alteration of the longitudinal connectivity in the Spanish rivers is the presence of obstacles and barriers as diversion channels, weirs and dams. From the II century when Cornalbo dam was arisen at Mérida (MOPU 1986) to nowadays, a large number of barriers have been built in Spain. Unfortunately, the current functionality degree of most of them is defective or unknown.

Consequently, the inventory of barriers was updated to determine the placement of each barrier in the fluvial network, among other interesting data like the high and width of the obstacle, very useful to determine its potential impact on the river longitudinal connectivity and fish populations.

These inventories should be permanent available to the public and it is the responsibility of the different River Basin District authorities to keep them updated with relevant information. Unfortunately not all the River Basin District has these inventories complete or facilitates their access and consultation by society.

For this research, we have used the inventory of barriers provided by the Duero River Basin District. This inventory can be downloaded from their website (www.mirame.chduero.es). However, this information was completed by González Fernández et al. (2010). This updated inventory includes some interesting parameters such as the construction material, use, conservation status, operability, permeabilization measures and passability of every barrier inventoried. In summary, according to this database there are 3539 obstacles collected in the inventory provided by the Duero River Basin Authorities.

\section{Subsection 3: Barriers classification according to ecological criteria}

Once the obstacles in the inventory have been located and synthetically described, a classification of them has been carried out based on the dam parameters, as physical as ecological, that better classify the barriers. 
Among the parameters included in the dam description, we have selected the 11 variables that best classify the obstacles based on ecological criteria. These parameters are: 1) Obstacle size, 2) Seasonality: if a barrier alters the water flow temporarily or permanently, 3) Total height of the dam wall, 4) Total width of the dam wall, 5) Material used for the construction of the obstacle, 6) Dam condition: good, moderate or bad, 7) Operational performance: if the barrier is in use or abandoned, 8) Use: The main functionality of the obstacle, 9) If the obstacle produces or not drought below its location, 10) Presence or not of a fishpass in the obstacle and 11) Passability: possibility for a fish to cross the obstacle in both directions, ascending and descending. All this selected parameters of the Duero River Basin dams are explained in more detail in Chapter III.

After removing the barriers with missing values of any of the selected parameters, the final dataset included 3,431 obstacles, a $96.95 \%$ out of former inventory.

After that, a Principal Component Analysis (PCA) (Jongman et al., 1995) has been carried out to determine the parameters that best classify the barriers of the Duero. PCA is a useful technique commonly used when we have a large number of possibly correlated variables to reduce them to a smaller number combination of variables that explain the most part of data variability. This analysis determines that the best variables to classify the studied barriers are: building material, use and passability. The classification produces a segmentation among barriers which facilitates the recognition of which ecological variables analysis of such as large set of objects and it yields.

All the analysis were conducted using $R \vee 3.3 .2$ software, library "MASS" ( $R$ Development Core Team 2016).

\section{Subsection 4: Conducting the interviews to the Stakeholder's and the generation of the Interconnection matrix}

As a part of the Fuzzy Cognitive Maps methodology, an interview to different stakeholders has been conducted in order to obtain as much information as possible from different groups of experts that provide different points of view to generate an objective response to the issue.

The template with the interviews format is attached below. These interviews have been used in Chapter III to obtain the individual matrices and the aggregated matrix that summarizes the expert's information. 


\section{Relations between Ecosystem Services and constituents of Human Well-being}

applied to the dam removal cost-benefit analysis in the Spanish fluvial ecosystems

Weir and dam management is an essential issue to recover longitudinal connectivity in rivers. Among these management measures, the removal of the obstacle that fragments connectivity has proven to be effective in the short-medium term. This removal should be done taking into account the Ecosystem Services provided by rivers without compromising the current socioeconomic conditions of the human populations affected by this management. Therefore, it is considered necessary to develop a methodology that allows combining both approaches so that decision making is as balanced as possible.

We want to assess the effect of dam removal on the river Ecosystem Services as well as on the Constituents of Human Wellbeing. To do this, we ask you to fill the following matrix of relationships, in which you can establish the causal relationships between the variables that constitute the fluvial ecosystem as well as the value or weight of this relationship. The relationship values assignment between variables should be done according to the following question: How does this variable influence the other variables? The value of this relationship can be both positive $(+)$ if the increase of the variable increases the value of other variables, and negative (-) if the increase of one variable decrease other variables. The values of these unions may be:

0 if there is no relationship between variables

0.5 if the strength of the interaction is of medium intensity

1 if the strength of the interaction is strong

A matrix of relationships is attached to establish the values between variables. The gray diagonal should not be filled. Relationships are established so that the variables of the columns influence the variables of the rows. Also, a document with the definitions of the Ecosystem Services and the Constituents of Human Well-being is attached to facilitate the understanding of the matrix variables.

\section{Definition of the Ecosystem Services provided by rivers:}

\section{Provisioning services}

- Aquiculture: source of food such as freshwater fish, crayfish and mollusks.

- Freshwater: water available. 
- Raw materials: Materials provides by rivers and riparian areas such as gravels, sand, clays, salts, mineral water, timber, reeds and willows, natural medicines, etc.

- Hydropower: use of a waterfall (usually artificial) to generate electricity.

- Genetic resources: richness in riparian (in and out-stream) species, especially in the endemic ones.

Regulating services

- Climatic regulation and carbon storage: freshwater ecosystems can moderate extreme temperatures and contribute to carbon uptake.

- Water regulation: alteration of natural river flow.

- Water quality: Self-purification water capacity and reduction of the organic and inorganic pollutants load.

- Sediments: transport, erosion and sedimentation: transport of sediments, organic and inorganic materials that contributes to the river floodplain fertilization. Riparian vegetation is a key component to buffering sediments from adjacent areas.

- Natural hazard mitigation: protection against floods and droughts.

- Biological control: Non-native species control.

Cultural services

- Scientific and local ecological knowledge: knowledge about the structure and function of aquatic ecosystems. Cultural heritage, knowledge based on experience of local people.

- Cultural identity and sense of belonging: human settlements located surrounding aquatic ecosystems and its special connection between them.

- Aesthetic and landscape values: Scenic beauty of the fluvial landscape and their sense of well-being.

- Recreation and ecotourism: outdoor activities in rivers or near them like rafting, kayaking, sailing, swimming, hiking, sunbathing....

- Sport fishing: Angling. Trout and salmon fly fishing. 
- Environmental education: programmes promoted and financed by public and private entities to raise the riparian awareness among citizens.

Definition of the Constituents of Human Well-Being:

Security

- Ability to live in an environmentally clean and safe shelter.

- Ability to reduce vulnerability to ecological shocks and stress.

Materials for a good life

- Ability to access resources to earn income and gain a livelihood.

Health

- Ability to achieve good quality of life.

Social relations

- Opportunity to express aesthetic, cultural and spiritual values associated with fluvial ecosystems.

- Opportunity to observe, study and learn about fluvial ecosystems

With this form, surveys were carried out to 25 experts in fluvial subjects of diverse nature. The experts consulted belong to universities, research centers, companies, public administrations, foundations, etc (table 3). 
Table 3. Number of participants in the survey and organization to which they belong.

\begin{tabular}{cc}
\hline Participating organizations & $\begin{array}{c}\text { Number of } \\
\text { participants }\end{array}$ \\
\hline $\begin{array}{c}\text { Universidad de Zaragoza } \\
\text { Universidad Politécnica de } \\
\text { Madrid. ETSI Montes, } \\
\text { Forestal y del Medio } \\
\text { Natural }\end{array}$ & 1 \\
IH Cantabria & 16 \\
Centro Europeo & \\
Prevención Riesgo & 1 \\
Inundación (CEPRI) & \\
Universidad de Florida & 2 \\
Ecohidraúlica SL & 1 \\
Canal de Isabel II & 1 \\
Universidad de Lisboa & 1 \\
Tragsatec & 1 \\
\hline
\end{tabular}

Of the participants surveyed, a total of 8 are university professors (including assistant professors, professors and full professors), 9 of them are PhD or master students, 2 two are researchers in research centers and 6 technicians belonging to public administrations and private companies.

The participants were contacted mainly by email, where the matrix of correlations and the document with the instructions and the definition of both the ecosystem services and the constituents of human well-being were included.

In this way, 25 individual maps or interrelation matrix were generated, representing the complexity and containing the variability of the system. Finally, a general matrix of interrelations with all the generated maps was made.

This matrix and the resulting cognitive map can be seen in more detail in the Appendix 2.

\section{Section 3: Data analysis}

Subsection I: Use of Conefor and connectivity indices to quantify fluvial habitat fragmentation.

\section{Conefor}

The connectivity analyses of fluvial systems studied were carried out using the software Conefor Sensinode 2.2 (Saura and Torné, 2009). Conefor is "a software 
package that allows quantifying the importance of habitat areas and links for the maintenance or improvement of landscape connectivity, as well as evaluating the impact of habitat and land use changes on connectivity. It is conceived as a tool for decision-making support in conservation and landscape planning, through the identification and prioritization of critical sites for ecological connectivity" (Saura and Torné, 2012).

This software has been developed to analyze terrestrial landscape mosaics in intricate networks of connections and therefore is based on the graph theory approach with a set of nodes and unions between them. In this way, the nodes represent sites of suitable habitat surrounded by an inhospitable matrix whose habitat quality is not sufficient for the species while links represent the potential capacity of movement of a species between a pair of nodes.

In Chapter I, we provide a different point of view regarding the consideration of the nodes and links of the graph in the rivers that we will advise that is more suitable and better fits the ecology of the river networks.

\section{Connections}

The connections between habitat patches when performing connectivity analysis can be binary (graphs with unweighted links) or probabilistic (graphs with weighted links) (Saura and Pascual-Hortal, 2007).

The binary model considers that two nodes are connected or not, without intermediate connection values. It is considered that this vision is a simplification of the possibility of movement or dispersion between patches of habitat. In this case, the existence of a union between nodes implies that an organism will have full capacity of movement between them.

The probabilistic model considers that the union between two nodes can have intermediate values that depend on an estimation of the strength, frequency or feasibility of direct movement by the analysed populations. This model determines that there may be a union between two patches of habitat depending on the parameters explained above, that is, an intensity in the value of movement between nodes can be assigned for a certain species and not only determines whether or not there is a connection. This type of connection allows, unlike the binary model, to know if the connection between areas of habitat is strong or weak and thus establish the greater probability of movement between the connections (figure 3 ). 
Binary model (yes/no)

\begin{tabular}{ccc}
\hline & & 3 \\
\hline From node & To node & Link \\
\hline 3 & 1 & 1 \\
\hline 3 & 2 & 1 \\
\hline 4 & 1 & 0 \\
\hline 4 & 2 & 0 \\
\hline 4 & 1 & 0 \\
\hline
\end{tabular}

Probabilistic model $(0-1)$

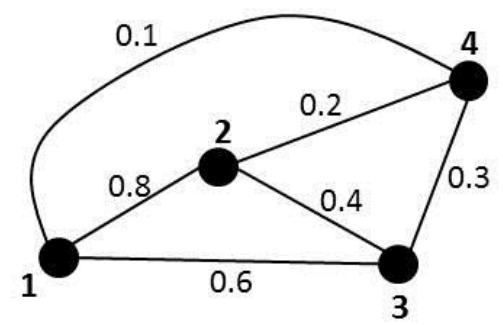

\begin{tabular}{ccc}
\hline From node & To node & Link \\
\hline 2 & 1 & 0.8 \\
3 & 2 & 0.4 \\
3 & 1 & 0.6 \\
4 & 3 & 0.3 \\
4 & 2 & 0.2 \\
4 & 1 & 0.1 \\
\hline
\end{tabular}

Figure 3. Differences in the quantification and determination of direct connections between nodes in the binary and probabilistic connection models. Adapted from Saura and PascualHortal (2007).

\section{Connectivity indices}

The program allows the calculation of several connectivity indexes, specifically six based on a binary connection model and three based on the probabilistic one (Saura and Pascual-Hortal, 2007). All of the indices measure functional connectivity at the landscape level, each one with its characteristics. Among this variety of indices, the authors recommend the use of two of the indices: the Integral Index of Connectivity (IIC) based on a binary connection (Pascual-Hortal and Saura, 2006), and the Probability of Connectivity index (PC) based on the probabilistic connection (Saura and Pascual-Hortal, 2007). "Both metrics are based on graph structures and on the concept of measuring habitat availability at the landscape scale" (Pascual-Hortal and Saura, 2006; Saura and Pascual-Hortal, 2007; Saura and Rubio, 2010; Saura et al., 2011).

The Integral Index of Connectivity (IIC) ranges from 0 to 1 for patches that are directly connected if the distance between them is below a certain threshold dispersal distance:

$I I C=\frac{\sum_{i=1}^{n} \sum_{j=1}^{n} a_{i} a_{j} /\left(1+n l_{i j}\right)}{A_{L}^{2}}($ eq. 1$)$ 
Where $n$ is the total number of nodes in the landscape, $a_{i}$ and $a j$ are the attributes of the nodes $i$ and $j$ or the area of each habitat patch, $\mathrm{nl}_{i j}$ is the number of links in the shortest path (topological distance) between patches $i$ and $j$ and $A_{L}$ is the maximum landscape attribute. For not connected nodes, the result of IIC equation equals zero. IIC increases with improved connectivity until the hypothetical case in which that IIC = 1 if all the landscape is occupied by habitat. A disadvantage of the IIC with respect to other binary indices is that to calculate the shortest paths between each pair of nodes it needs more computing capacity (Saura and Pascual-Hortal, 2007).

The Probability of Connectivity Index (PC) is defined as "the probability that two points randomly placed within the landscape fall into habitat areas that are reachable from each other (interconnected) given a set of $n$ habitat patches and the links or direct connections $\left(p_{i j}\right)$ among them" (Saura and Pascual-Hortal, 2007; Saura and Rubio, 2010).

It ranges from 0 to 1 and increases with improved connectivity. It is given by the following expression:

$P C=\frac{\sum_{i=1}^{n} \sum_{j=1}^{n} a_{i} a_{j} p_{i j}^{*}}{A_{L}^{2}}$ (eq. 2)

Where $n$ is the total number of nodes in the landscape, $a_{i}$ and $a j$ are the attributes of the nodes $i$ and $j$ or the area of each habitat patch, $A_{L}$ is the maximum landscape attribute (both habitat and non-habitat), and $p^{*}{ }_{i j}$ is the maximum product probability of all possible paths between patches $i$ and $j$ (including single-step paths). If patches $i$ and $j$ are close enough, the maximum probability path will simply be the step (direct movement) between patches $i$ and $j\left(p^{*} i j=p_{i j}\right)$.

For that reasons, the authors consider that the PC index is a improved connection model than IIC for the following reasons: (1) in the PC, the attribute values can also refer to other different meanings (or patch characteristics that may be considered relevant for the analysis) from patch area such as habitat quality, population size, carrying capacity, habitat suitability, etc. (2) It is "not affected by the presence of adjacent habitat patches or cells in the analysed dataset" (Saura and Pascual-Hortal, 2007), and (3) The IIC is a connection index based on the binary system in which two habitat patches are connected or not connected without intermediate modulation of the strength of the connection between both patches and viability of dispersion, while the probabilistic connection model of the PC allows the continuous modulation of the connection strength or dispersal feasibility (Saura and Rubio, 2010). 
So far the importance of both indices has been established to estimate the general connectivity of the landscape; however it is more interesting for the managers to know the contribution of each node in particular in order to be able to establish rankings of importance or prioritization of landscape elements (patches and links) (Keitt et al., 1997; Urban and Keitt, 2001; Pascual-Hortal and Saura, 2006; Saura and PascualHortal, 2007). The contribution of each node to the overall connectivity and habitat availability will be made by calculating the variations in the IIC and in the PC that will occur after the removal of a particular node in the network. To measure the change, comparisons are made with the delta values of each index (Pascual-Hortal and Saura, 2006) according the following expression:

$d I=100 \cdot \frac{I-I^{\prime}}{I}($ eq. 3$)$

Where $I$ is the index value before the change and $I$ ' the value of the same index after the change.

For the case of the IIC and the PC, the values of dIIC and IPC are obtained given that $d$ means the percentage of the variation:

$d I I C_{k}=100 \cdot \frac{I I C-I I C_{\text {remove }}}{I I C}($ eq. 4$)$

$d P C_{k}=100 \cdot \frac{P C-P C_{\text {remove }}}{P C}($ eq. 5)

Where $d \| C_{k} / d P C_{k}$ is the importance of element $k$ for the maintenance of overall habitat availability in the landscape. IIC/PC is the metric value in the intact landscape, when each of the original components is present including $k$. The concept remove is the metric value after the removal of $k$ (Saura and Rubio, 2010).

The importance of the contribution of landscape elements to the overall connectivity can be divided into three sub-indices:

dIIC = dIICintra + dIICflux + dIICconnector

$d P C=d P C i n t r a+d P C f l u x+d P C$ connector

The intra fraction represents the intrapatch connectivity (habitat resources that can be reached within a given node, without moving to other habitat patches). This fraction is independent of how a node is connected with the others. The flux fraction reflects how well connected a node is to the rest of the habitat nodes in the landscape network. The connector fraction represents how important a given node is for maintaining the rest of the habitat nodes connected to each other. This fraction works like connecting 
element or "stepping stone" between nodes and depends only of the topological position of a node or link in the network (Saura and Rubio, 2010). These fractions provide non-redundant and complementary information on the importance of a node or habitat patch into the landscape network and can be determinants in the prioritization of node conservation (Baranyi et al., 2011; Saura and Torné, 2012).

To calculate the IIC we used the Conefor 2.6 version. The calculation of the PC index for asymmetric graphs was performed through a purposefully developed version of the Conefor command line.

Link improvement or the potential benefits of strengthening the connection among patches

The Conefor 2.6 version (Saura and Torné, 2012) allows the application of the "link improvement" option, which implies that whatever the value of a union between two nodes, it will reach its maximum value which means that the capacity of movement between the two selected nodes will now be total. This option can be used both for the binary connection model (IIC) and the probabilistic one (PC). In this last, "Conefor will calculate the potential (positive) impacts of improving as much as possible the direct connection (link) between each pair of patches (only one at a time)".

This translates as the connection between a pair of nodes having a probability equal to 1 of conducting movement, i.e. the probability of circulation between two nodes will be 1 rather than the connectivity value it had before, unless this connection already had a value of 1 in the initial situation.

The features of river segments make less functional the use of the IIC index in fluvial analysis, due to a segment is connected to two -or maximum three- adjacent segments. The lack of importance graduation produces a similar effect no matter what segment is deleted, so that the IIC cannot reflect the importance of a certain river node.

In this thesis this option has only been used for the probabilistic connection model (PC).

\section{Subsection II: Fuzzy Cognitive Maps}

Introduction to cognitive mapping

The classic definition of a cognitive map is "a qualitative model of how a given system operates" (Özesmi and Özesmi, 2004). The foundations of the Fuzzy cognitive maps 
arise from graph theory (Özesmi and Özesmi, 2003). Cognitive maps are directed graphs or digraphs (Axelrod 1976). It was Kosko (1986) who added the diffuse term to cognitive maps, modifying Axelrod's map applying diffuse causal relationships with values between $[-1,1]$ for connections (Özesmi and Özesmi, 2003, 2004). The graph and the corresponding matrix of interrelations can represent causal effects that nodes have on each other if the edges are directional and appropriate weights are given. These maps may be either cyclic or acyclic, although the latter are more unusual (Kafetzis et al., 2010).

FCMs consist of a set of nodes and weighted links, which are graphically illustrated as a signed weighted graph with feedback. Nodes of the graph represent the concepts describing behavioral characteristics of the system whereas the signed weighted links represent the interconnections between nodes and the causal relationships that exist among them. The edges have numerical values that can be fuzzy weights, fuzzy degrees of belief, or fuzzy entailments represented by each edge in the graph (Kafetzis et al., 2010). This graphic display shows which concept influences other concept and what the degree of influence among them is (Stylios and Groumpos, 2004), so each FCM is a graphical summary of if-then causal statements or entailments (Kafetzis et al., 2010).

FCMs can be used to calculate how different points of view suggest different inferences on the subject of study (Helfgott et al., 2015). For this purpose, a series of variables or concepts that describe the functioning of a determined system are determined. "The value of the variables themselves is not quantified during the process of cognitive mapping, so it does not matter if they are quantifiable or not" (Helfgott et al., 2015).

According to Özesmi and Özesmi (2004) and Helfgott et al. (2015), the way to develop cognitive maps in participatory processes has the following steps: (1) an interview with the participants is carried out to develop a brainstorm about the most relevant concepts of the topic to analyze, (2) the most relevant concepts will be grouped by the organizers to avoid unnecessary repetition of concepts with the aim of facilitating the understanding of the future cognitive map, (3) once the most relevant concepts are determined and grouped into concrete variables, the participants draw lines (arrows) between them to indicate the possible causal relationships between the determined variables. The direction of the arrow indicates that the emitting variable affects the receiving variable in some way, (4) in the next phase, the participants add a sign to the links between variables. This sign is positive $(+)$ if the participant believes that one 
variable causes a positive effect or increase on another variable. On the other hand, the sign is negative (-) if the participant considers that the variable causes a negative or decrement effect on another variable, (5) in this point, participants can assign a value to each union that represents the weight or value of the causal relationship. These values, for the fuzzy maps, are established in the range $[-1,1]$ with -1 being the maximum value of causal decrease, 0 when there is no causality and +1 the maximum value of causal growth.

The result of the interactions of each map can be represented in an adjacency matrix (Axelrod 1976). According to graph theory, cognitive maps can be transformed into adjacency matrix as follows: $A(D)=\left[a_{i j}\right]$ (Özesmi and Özesmi, 2003, 2004). In this matrix, the $i j^{\text {th }}$ element $a_{i j}$ gives the value on the link between concept $i$ and $j$ (Helfgott et al., 2015).

The interest of using FCMs lies in their ability to represent complex problems and allow an interface between quantitative and qualitative approaches (Kafetzis et al., 2010). Also, they are an especially attractive technique for modeling systems characterized by "their uncertainty, ambiguity or non-trivial causalities among their variables" (Nápoles et al., 2018).

\section{Graph Theory and Fuzzy Cognitive Maps}

Graph theory indices can help interpret the structure of cognitive maps (Özesmi and Özesmi, 2003, 2004). These maps are compounds of a large number of variables with its interconnections, which makes it a complex system. However the tools of graph theory allow us to analyze their structure.

Depending on the number of different types of variables, other indices can be calculated. First, the density of a fuzzy cognitive map $(D)$ shows how connected or dispersed the maps are. This index of connectivity represents the number of connections divided by the maximum number of connections possible between $\mathrm{N}$ variables (Özesmi and Özesmi, 2003, 2004). If the map density is high, it means that the participant perceives a large number of casual relationships among variables (Özesmi and Özesmi, 2004).

The structure of cognitive maps can also be analyzed according to the type of variables they have, which may be of the type transmitter, receiver and ordinary.

These variables are defined by their outdegree and indegree. Outdegree is "the row sum of absolute values of a variable in the adjacency matrix and shows the cumulative 
strengths of connections exiting the variable" (Özesmi and Özesmi, 2003, 2004). It is a measure of how much a given variable influences other variables or the number of connections leading from one variable to other variables (Bougon et al., 1977; Papageorgiou and Kontogianni, 2012). Indegree is "the column sum of absolute values of a variable" (Özesmi and Özesmi, 2003, 2004). It shows the cumulative strength of variables entering the unit or the number of connections leading to the variable from other variables (Bougon et al., 1977; Papageorgiou and Kontogianni, 2012). The sum of the value of the outdegree and the indegree results in the centrality value of $a$ variable. It is an important concept since to determine the contribution of a variable to the cognitive map it is necessary calculate its centrality, which shows how connected the variable is to other variables and what is the cumulative strength of the connection (Özesmi and Özesmi, 2003, 2004).

Graph theory also provide an effective way to understand the structure of cognitive maps by condensing them which means the replacement of subgraphs (a set of connected variables) for a single unit. The individual maps are qualitatively aggregated using clustering concepts to generate a condensed map known as collective FCM. When a map becomes very complex due to the large number of variables and links between them, the most central variables with their weighted connections are usually represented (Papageorgiou and Kontogianni, 2012).

\section{Stakeholders and expert knowledge}

One of the strengths of the FCM methodology is that it is based on the collection of expert knowledge on a subject. FCMs represent human knowledge about how the system works (Groumpos 2010).

The grouping of different expert knowledge on a specific topic is one of the strengths of the FCM when gathering a great variety of points of view that allows determining a vision as realistic as possible of complex systems. On the other hand, when consulting different experts on a topic with the objective of developing a FCM each expert will have different experience and subjective knowledge of the subject. Because of this, we should consider that there will be experts with different degrees of credibility about the knowledge they can bring to the topic. In these cases the contribution of some experts can be multiplied by a coefficient of "credibility" that balances the opinions of the experts (Groumpos 2010). This "credibility" value can also be applied to the different stakeholder groups to try to reduce the possible perception bias of each group. This is especially useful in cases in which the participants are very different 
groups and it is necessary to establish a criterion that modulates the different responses.

\section{Aggregation process}

One of the important points of the FCM is the aggregation of the individual maps generated by each participant in the process of creating the map into an aggregate map that collects all the information of the interviewees. In this way, this combination produces a larger representative knowledge of all the participants (Helfgott et al., 2015). A classic form of aggregation of individual maps may be the one proposed in chapter II of the thesis. However, other authors propose alternative aggregation methods (Groumpos 2010; van Vliet et al., 2017).

According to Kosko 1988, "larger expert sample sizes should produce more reliable knowledge bases". The combination of weighted FCMs can reflect different levels of expertise on the area. However, there is a complication because each individual map represents the perspective of the person who has made it and therefore the combination of maps of several participants does not imply the same result for the combined map (Helfgott et al., 2015).

For this reason, although the number of experts involved increases, the form of the aggregate FCM in terms of variables and the weight between them will be able to stabilize and constitute a good representation of the state of knowledge of the topic to analyze (Helfgott et al., 2015).

At the present time, there is not a current consensus on what is the best way to construct the aggregated Fuzzy Cognitive Map and even more studies are needed to explore the effects of different aggregation methods (van Vliet et al., 2017).

\section{Initial state vector to generate scenario simulations}

"FCMs can be represented mathematically in the form of a vector and a matrix, where the vector represents the weight of the variables in the system" (van Vliet et al., 2017). These maps can be used to make inferences about causation from a given set of initial conditions. These conditions collected in a vector form may represent a policy or program intervention (for example the decision to remove or not a barrier) that activates particular concepts (Helfgott et al., 2015). "Inferences are extracted from the FCM by using it to form a standard matrix product with an i-element state vector whose elements are the initial values of the i concepts at the start of the process" (Kafetzis et al., 2010). This vector represents the initial state of concepts identified by 
the available knowledge (Özesmi and Özesmi, 2003; Papageorgiou and Kontogianni, 2012). These changes in a series of starting conditions can be used to analyze the behavior of the system by running simulations that can determine future possible management scenarios.

Each simulation process starts with an initial vector that represents the present events at a given time, and a final vector that represents the final state reached for each simulation (Papageorgiou 2010). These simulations are made by multiplying the initial state vector $\left(A_{1}\right)$ by the adjacency matrix of the aggregate $F C M\left(E_{c}\right)$, where $A_{1}$ is a row vector of size $1 \times N$, where $N$ is the total number of variables (Tan and Özesmi, 2006). The resultant vector of the multiplication is considered as the new initial vector for the next iteration. The iterations continue until equilibrium is reached or not. The iterative process of multiplication of vectors by the matrix can be seen in figure 4 .

The process of simulation begins when a value of 0 or 1 is assigned to each variable. A value of 0 will represent non-activate concepts and therefore it would not contribute at the next iteration, whereas a value of 1 means that the concept is totally activated and would represent a contribution at the next iteration. In each iteration, the filter function is applied producing a new state vector with activate concepts (1) and nonactivated concepts (0). If a concept has an activation value of 0 , this concept would not contribute at the next iteration, whereas an activation value of 1 would represent the contribution at the next iteration. 


$$
\begin{aligned}
& \text { Iteration: } 1 \\
& A_{1}\left(a_{1 \mid 1, \ldots, p}, a_{2 \mid 1, \ldots, p}, a_{3 \mid 1, \ldots, p}, \ldots, a_{N \mid 1, \ldots, p}\right) \cdot E_{C}\left[\begin{array}{ccc}
e_{11} & \cdots & e_{11} \\
\vdots & \ddots & \vdots \\
e_{1 N} & \cdots & e_{N N}
\end{array}\right]=\left(a_{1}, a_{2}, a_{3}, \ldots, a_{N}\right) \\
& f_{l}\left(a_{1}, a_{2}, a_{3}, \ldots, a_{N}\right) \cdot f_{u}\left(a_{1}, a_{2}, a_{3}, \ldots, a_{N}\right)^{\prime}=A_{2}\left(a_{1 \mid 1, \ldots, p}, a_{2 \mid 1, \ldots, p}, a_{3 \mid 1, \ldots, p}, \ldots, a_{N \mid 1, \ldots, p}\right) \\
& \text {... } \\
& \text { Iteration: } 2 \\
& A_{2}\left(a_{1 \mid 1, \ldots, p}, a_{2 \mid 1, \ldots, p}, a_{3 \mid 1, \ldots, p}, \ldots, a_{N \mid 1, \ldots, p}\right) \cdot E_{c}\left[\begin{array}{ccc}
e_{11} & \cdots & e_{11} \\
\vdots & \ddots & \vdots \\
e_{1 N} & \cdots & e_{N N}
\end{array}\right]=\left(a_{1}, a_{2}, a_{3}, \ldots, a_{N}\right) \\
& f_{l}\left(a_{1}, a_{2}, a_{3}, \ldots, a_{N}\right) \cdot f_{u}\left(a_{1}, a_{2}, a_{3}, \ldots, a_{N}\right)^{\prime}=A_{3}\left(a_{1 \mid 1, \ldots, p}, a_{2 \mid 1, \ldots, p}, a_{3 \mid 1, \ldots, p}, \ldots, a_{N \mid 1, \ldots, p}\right) \\
& \text {... } \\
& \begin{array}{l}
\text { Iteration: } i-1 \\
A_{i-1}\left(a_{1 \mid 1, \ldots, p}, a_{2 \mid 1, \ldots, p}, a_{3 \mid 1, \ldots, p}, \ldots, a_{N \mid 1, \ldots, p}\right) \cdot E_{c}\left[\begin{array}{ccc}
e_{11} & \cdots & e_{11} \\
\vdots & \ddots & \vdots \\
e_{1 N} & \cdots & e_{N N}
\end{array}\right]=\left(a_{1}, a_{2}, a_{3}, \ldots, a_{N}\right) \\
f_{l}\left(a_{1}, a_{2}, a_{3}, \ldots, a_{N}\right) \cdot f_{u}\left(a_{1}, a_{2}, a_{3}, \ldots, a_{N}\right)^{\prime}=A_{i}\left(a_{1 \mid 1, \ldots, p}, a_{2 \mid 1, \ldots, p}, a_{3 \mid 1, \ldots, p}, \ldots, a_{N \mid 1, \ldots, p}\right)
\end{array}
\end{aligned}
$$

Figure 4. The iterative process of the FCM, in which the state vector A is multiplied iteratively by the adjacent matrix $E_{c}$ until an equilibrium vector is reached. The lower threshold filters $f_{l}$ and upper threshold filters $f_{u}$ are applied in each iteration and level to regenerate the state variables as categorical.

The next step will allow obtaining answers to management scenarios by asking "whatif" questions to determine the state of the system that would be developed under different conditions or if different policy options were implemented (Kosko 1987). FCMs have the capacity of predicting and redesigning the studied system through the generation of scenarios by performing simulations from different initial state vectors when we impose different initial conditions on concepts (Groumpos 2010, Stach et al., 2010, Papageorgiou and Kontogianni, 2012). These simulations provide a description of the behavior of the system that can be used to generate predictions that may help decision makers in the implementation of management strategies (Stach et al., 2010, Papageorgiou and Kontogianni, 2012).

The calculation of the outdegree (the strength with which a system concept influences others), indegree (the strength with which a system concept is influenced by others) and centrality (how connected is the system concept within the system representing its general importance), as well as the simulation of different management scenarios (pre- and post-dam removal) were conducted using the software tools Fuzzy Cognitive Mapping \& Modelling (Bachhofer and Wildenberg, 2010) (freely available in 
www.fcmappers.net) and Mental Modeler (Gray et al., 2013) (freely available in www.mentalmodeler.org).

\section{Literature cited}

Axelrod R. 1976. Structure of Decision: the Cognitive Maps of Political Elites, Princeton, NJ, USA, Princeton University Press.

Bachhofer M, Wildenberg M. 2010. FCMappers. http://www.fcmappers.net.

Baranyi G, Saura S, Podani J, Jordán F. 2011. Contribution of habitat patches to network connectivity: redundancy and uniqueness of topological indices. Ecol Indic 11:1301-1310

Bougon M, Weick K, Binkhorst D. 1977. Cognition in organizations: An analysis of the Utrecht Jazz Orchestra. Administrative Science Quarterly, 606-639.

Confederación Hidrográfica del Duero (CHD). 2009. Plan hidrológico del Duero. Plan hidrológico de la parte española de la demarcación hidrográfica del Duero propuesta de proyecto de plan hidrológico de cuenca. España

$\begin{array}{llll}\text { Confederación Hidrográfica del } & \text { Duero }\end{array}$ (http://www.chduero.es/Inicio/Organismo/LacuencadelDuero/Caracter\%C3\%A Dsticasgenerales/tabid/86/Default.aspx) Last Access July 2019.

Estudios Territoriales Integrados 1997. Estudio de las poblaciones piscícolas del río Cega. Informe inédito. Junta de Castilla y León, Consejería de Medio Ambiente y Ordenación del Territorio.

Estudios Biológicos 1998. Segundo muestreo piscícola en la cuenca del río Cega (Segovia). Informe inédito. Junta de Castilla y León, Consejería de Medio Ambiente y Ordenación del Territorio.

González Fernández G, Pérez Cardenal D, Miguelez Carbajo D, Gallego García R, Fernández Suárez R, Álvarez Durango E, Canal Rubio P, Roa Álvarez I, Rosa Cubo E, Seisdedos Fidalgo P. 2010. Diagnóstico de la conectividad longitudinal en la Cuenca del Duero. Ministerio de Medio Ambiente, Medio Rural y Marino. Available in http://www.chduero.es/acciona5/metodologia/ic.pdf

Groumpos PP. 2010. Fuzzy cognitive maps: Basic theories and their application to complex systems. In Fuzzy cognitive maps (pp. 1-22). Springer, Berlin, Heidelberg.

Gray SA, Gray S, Cox LJ, Henly-Shepard S. 2013. Mental modeler: a fuzzy-logic cognitive mapping modeling tool for adaptive environmental management. In 2013 46th Hawaii International Conference on System Sciences (pp. 965-973). IEEE.

Hage P, Harary F. 1995. Eccentricity and centrality in networks. Social networks, 17(1), 57-63. 
Helfgott A, Lord S, Bean N, Wildenberg M, Gray S, Gray S, Vervoort J, Kok K, Ingram J. 2015. Clarifying Fuzziness: Fuzzy Cognitive Maps, Neural Networks and System Dynamics Models in Participatory Social and Environmental Decision-aiding Processes. Global Environmental Change no. Submitted.

Hobbs BF, Ludsin SA, Knight RL, Ryan PA, Biberhofer J, Ciborowski JJH. 2002. Fuzzy cognitive mapping as a tool to define management objectives for complex ecosystems. Ecol. Appl. 12, 1548-1565.

Jetter AJ. 2006. Fuzzy cognitive maps for engineering and technology management: what works in practice? In Technology Management for the Global Future, 2006. PICMET 2006 (Vol. 2, pp. 498-512). IEEE.

Jongman RHG, ter Braak CJF, Van Tongeren OFR. 1995. Data analysis in community and landscape ecology. Cambridge University Press.

Kafetzis A, McRoberts N, Mouratiadou I. 2010. Using fuzzy cognitive maps to support the analysis of stakeholders' views of water resource use and water quality policy. In Fuzzy cognitive maps (pp. 383-402). Springer, Berlin, Heidelberg.

Keitt TH, Urban DL, Milne BT. 1997. Detecting critical scales in fragmented landscapes. Conservation ecology, 1(1).

Kontogianni A, Papageorgiou E, Salomatina L, Skourtos M, Zanou B. 2012. Risks for the Black Sea marine environment as perceived by Ukrainian stakeholders: A fuzzy cognitive mapping application. Ocean \& Coastal Management, 62, 34-42.

Kosko B. 1986. Fuzzy cognitive maps. International Journal of Man-Machine Studies 1, 65-75.

Kosko B. 1987. Adaptive inference in fuzzy knowledge networks. In: Proceedings of the First IEEE International Conference on Neural Networks (ICNN-86), San Diego, CA, pp. 261-268.

Kosko B. 1988. Hidden patterns in combined and adaptive knowledge networks. International Journal of Approximate Reasoning, 2(4), 377-393.

Martínez-Fernández V. 2018. Riberas fluviales en ríos regulados por grandes presas: delineación automática y respuestas bio-geomorfológicas. PhD thesis. Escuela Técnica Superior de Ingeniería de Motes, Forestal y del Medio Natural. Universidad Politécnica de Madrid, Madrid.

Ministerio de Obras Públicas y Urbanismo (MOPU). 1986. Inventario de presas españolas. Dirección General de Obras Hidráulicas.

Morán-Tejeda E, Ceballos-Barbancho A, Llorente-Pinto JM. 2010. Hydrological response of Mediterranean headwaters to climate oscillations and land-cover changes: The mountains of Duero River basin (Central Spain). Global and Planetary Change, 72(1-2), 39-49. 
Nápoles G, Espinosa ML, Grau I, Vanhoof K. 2018. FCM Expert: Software Tool for Scenario Analysis and Pattern Classification Based on Fuzzy Cognitive Maps. International Journal on Artificial Intelligence Tools, 27(07), 1860010.

Özesmi U, Özesmi S. 2003. A participatory approach to ecosystem conservation: fuzzy cognitive maps and stakeholder group analysis in Uluabat Lake, Turkey. Environmental management, 31(4), 0518-0531.

Özesmi U, Özesmi SL. 2004. Ecological Models based on People's Knowledge: A MultiStep Fuzzy Cognitive Mapping Approach. Ecological Modelling. 176, 43-64.

Papageorgiou El. 2010. A Novel Approach on Constructed Dynamic Fuzzy Cognitive Maps Using Fuzzified Decision Trees and Knowledge-Extraction Techniques. In Fuzzy cognitive maps (pp. 43-70). Springer, Berlin, Heidelberg.

Papageorgiou El, Kontogianni A. 2012. Using Fuzzy Cognitive Mapping in Environmental Decision Making and Management: A Methodological Primer and an Application. International Perspectives on Global Environmental Change. Dr. Stephen Young (Ed.), InTech

Paredes-Arquiola J, Martínez-Capel F, Solera A, Aguilella V. 2011. Implementing environmental flows in complex water resources systems-case study: the Duero river basin, Spain. River Research and Applications, 29(4), 451-468.

Pascual-Hortal L, Saura S. 2006. Comparison and development of new graph-based landscape connectivity indices: towards the priorization of habitat patches and corridors for conservation. Landscape Ecol. 21:959-967.

Santiago JM, García de Jalón D, Alonso C, Solana J, Ribalaygua J, Pórtoles J, Monjo R. 2016. Brown trout thermal niche and climate change: Expected changes in the distribution of cold-water fish in central Spain. Ecohydrology, 9(3), 514-528.

Saura S, Pascual-Hortal L. 2007. A new habitat availability index to integrate connectivity in landscape conservation planning: comparison with existing indices and application to a case study. Landscape Urban Plan 83:91-103

Saura S, Pascual-Hortal L. 2007. Conefor Sensinode 2.2 User's manual. University of Lleida. Available at www.conefor.org.

Saura S, Torné J. 2009. Conefor Sensinode 2.2: a software package for quantifying the importance of habitat patches for landscape connectivity. Environmental Modelling \& Software 24: 135-139.

Saura S, Rubio L. 2010. A common currency for the different ways in which patches and links can contribute to habitat availability and connectivity in the landscape. Ecography 33:523-537

Saura S, Estreguil C, Mouton C, Rodríguez-Freire M. 2011. Network analysis to assess landscape connectivity trends: application to European forests (1990-2000). Ecological Indicators, 11(2), 407-416. 
Saura S, Torné J. 2012. Conefor 2.6 user manual (April 2012). Universidad Politécnica de Madrid. Available at www.conefor.org.

Stach W, Kurgan L, Pedrycz, W. 2010. Expert-based and computational methods for developing fuzzy cognitive maps. In Fuzzy Cognitive Maps (pp. 23-41). Springer, Berlin, Heidelberg.

Stylios CD, Groumpos PP. 2004. Modeling complex systems using fuzzy cognitive maps. IEEE Transactions on Systems, Man, and Cybernetics-Part A: Systems and Humans, 34(1), 155-162.

Tan CO, Özesmi U. 2006. A generic shallow lake ecosystem model based on collective expert knowledge. Hydrobiologia, 563(1), 125-142.

Urban D, Keitt T. 2001. Landscape connectivity: a graph-theoretic perspective. Ecology, 82(5), 1205-1218.

van Vliet M, Flörke M, Varela-Ortega C, Çakmak EH, Khadra R, Esteve P, D'Agostino D, Dudu H, Bärlund I, Kok K, 2017. FCMs as a common base for linking participatory products and models. In: Gray S, Paolisso M, Jordan R, Gray S. (Eds.), Environmental Modeling with Stakeholders, Theory, Methods and Applications, pp. 145-170 (chapter 8). 


\section{PART 3. RESULTS}

"Esta magia no es un juego al que nos dedicamos por placer o por halago. Piénsalo: en nuestro Arte, cada palabra que pronunciamos, cada acto que ejecutamos es para bien o para mal. iAntes de obrar o hablar hay que conocer el precio!"

Ursula K. Le Guin. Un mago de Terramar 


\section{Chapter I}

"Una parte de hacer buena ciencia consiste en ver lo que cualquiera puede ver, pero pensar lo que nadie más ha dicho"

Amos Tversky 


\section{Longitudinal connectivity loss in a riverine network: Accounting for the likelihood of upstream and downstream movement across dams}

This chapter reproduces entirely the paper published in:

Rincón G, Solana-Gutiérrez J, Alonso C, Saura S, García de Jalón D. 2017. Longitudinal connectivity loss in a riverine network: Accounting for the likelihood of upstream and downstream movement across dams. Aquatic Sciences 79:573-585

\section{Abstract}

Disruption of longitudinal connectivity is a major concern in most of the world's rivers. Approaches based on graph theory have proven to be a suitable tool for analysing functional connectivity. However, previous applications of graph-based connectivity methods to river systems have been oversimplified in that they have treated potential barriers as binary features and rivers as symmetric networks.

We here apply a network analytical approach in which (a) upstream and downstream connectivity are considered so that fish passability values across dams are asymmetrical, and (b) it is possible to consider a continuous range of passability values for every dam. We build on previous and widely used connectivity metrics (Probability of Connectivity, PC), which here are generalised and adapted toward that end. We compare the results of our approach with those that would be obtained under the more simplified assumptions of symmetric movement and of barriers as binary features.

We want to prove if there are substantial differences between considering or not the asymmetry in river networks. The application of symmetrical and asymmetrical PC highlights major differences between the upstream connectivity versus the downstream connectivity. We provide our methods in a free software package so that they can be used in any other application to riverscapes.

We expect to provide a better graph-based approach for the prioritisation of the removal or permeabilization of artificial obstacles as well as for the preservation of target river segments for connectivity conservation and restoration.

Keywords: Longitudinal connectivity, fish passability, graph theory, directional networks, asymmetric dispersal, riverscapes. 


\section{Introduction}

Connectivity is the extent to which a species or populations can move among landscape elements in a mosaic of habitat types (Hilty et al., 2006). This concept is an essential property for the functioning of ecosystems (Kondolf et al., 2006). It is especially important for sustaining ecological flows (i.e. matter and energy) and the movement of genes, individuals or populations (Nicola et al., 1996, Calabrese and Fagan 2004). Given the decisive role of connectivity for the long-term persistence of biodiversity, it is widely acknowledged that it should be considered in decision-making and in the management planning processes in landscapes and riverscapes (Erös et al., 2011).

Rivers are considered as the epitome of connectivity (Wiens 2002). Therefore, special attention must be paid to the longitudinal dimension of connectivity (Ward 1989; Tockner et al., 1998; Lucas and Baras, 2001). Human activities, such as flow regulation produced by dams, disrupt the upstream - downstream linkages (Ward 1989). More specifically, dams reduce connectivity and, by doing so, they hinder or impede fish migration up or downstream and increasing demographic isolation of the biological populations (Schick and Lindley, 2007).

The loss of longitudinal connectivity in rivers as a result of dam development is a major worldwide problem (Gough et al., 2012). In the European Union, the EU Water Framework Directive (WFD, 2000/60/CE) considers river continuity as one of the aims for achieving good ecological status of the water bodies. River continuity is defined as having "no disruption of migration of aquatic organisms and sediment transport". Restoration of the longitudinal connectivity of rivers will have positive impacts on freshwater fish populations, especially on those obligated to migrate to complete their life cycle (Segurado et al., 2014). However, limited budget allocations often restrict the extent of connectivity restoration programmes. Therefore, it is necessary prioritise connectivity restoration actions in order to maximise their benefits for the riverine network functioning (Rivers-Moore et al., 2016). The strategy often depends on assessment of the contribution of every barrier to the overall loss of connectivity, as well as a subsequent ranking of the relevance of the removal of every barrier to the restoration of connectivity.

The graph-based methodology has proven to be a useful tool for quantifying the overall habitat connectivity of freshwater systems (Schick and Lindley, 2007; Erös et al., 2011, 2012; Carranza et al., 2012), being a widely used technique in terrestrial landscapes (Minor and Urban, 2007, 2008; Bodin and Saura, 2010; Saura and Rubio, 
2010). Ecological systems can be represented as graphs or networks that contain nodes depicting individual elements and links representing relationships between the nodes (Bodin 2009, Erös et al., 2012). Based in this concept, software tools like Conefor (Saura and Torné, 2009) have been developed. River segments and barriers can be represented in the graph, and their individual importance in the overall connectivity of the river system can be assessed. This approach yields a value of the overall connectivity of a given river network, and the partial contribution of every single obstacle to the loss of overall connectivity.

Previous applications of graph theory quantifying the longitudinal connectivity loss in riverine systems and ranking barriers have relied in two main assumptions: (1) barrier passability values are binary (or impassable or totally passable), and (2) nondirectionality movement (see Erös et al., 2011; Segurado et al., 2013, 2014). These assumptions about the symmetric passability of barriers do not agree with the idea of the importance of asymmetry in river systems. Asymmetry of movement in dendritic ecological networks (Grant, Lowe and Fagan 2007) is an extremely important concept in the analyses of metapopulations in rivers and possible biases in the upstreamdownstream movements (Grant 2011). Therefore, the consideration of directionality in riverine networks is needed in order to build up more ecologically realistic and functional models (Padgham and Webb, 2010). We propose to take the idea of Segurado et al. (2013) and improve it by considering the asymmetry of the obstacles passability. We will test the efficiency of this improvement by comparing both approaches: one assuming symmetric passability and a more realistic one taking into account the asymmetry.

To do this, we applied a graph-based approach to account for asymmetrical passability in river connectivity assessments obtaining different graph resolutions to prioritise barriers. We used a directional version of the Probability of Connectivity (PC) metric (Saura and Pascual-Hortal, 2007) differing between upstream and downstream passability for barriers (González Fernández et al., 2010). We quantified the loss of overall connectivity in a real river system due to obstacles through the comparison of two landscape connectivity indices: Integral Index of Connectivity (IIC) (Pascual-Hortal and Saura, 2006), which relies in binary barriers, and the Probability of Connectivity (PC), which allows for a continuous range of passability values to be assigned to each barrier. By comparing the results of both indices, we assessed the effect of assuming symmetrical passabilities and binary barriers in the overall account of connectivity and in related barrier prioritization. 
To test the error caused by not taking into consideration the asymmetry, we estimated the overall connectivity of two scenarios in a case study: (1) assuming symmetry in the passability of every obstacle; and (2) considering the asymmetry of the barriers that are really, which is in line with reality. Both situations could not be very different, but both are a real case study and then representative of the problem. If the results are different when considering or not asymmetry, a description of these differences allow explain the error committed if we assume that all obstacles are symmetrical in a real case. Higher values of overall connectivity are expected to occur when obstacles have different passability values in both directions. By doing so, we expect to provide a better graph-based approach, and to quantify the difference they make compared to previous graph-based assessments in rivers, for the prioritisation of the removal or permeabilization of artificial obstacles, as well as for the preservation of target river segments for connectivity conservation and restoration.

Mediterranean river systems exhibit large flow variability and frequently are naturally disconnected during part of the year. This hydrological variability produces unequal changes in upstream and downstream fish passabilities. For this reason determining connectivity losses in Iberian rivers is an issue (Branco et al., 2012). This study provides the approach of considering the movement in both directions, upstream and downstream, to implement a methodology that better fits the natural river conditions. In this regard, it is advisable to apply the idea of asymmetry for a better representation of the impact on connectivity and the movement of fish species due to the presence of artificial obstacles.

\section{Materials and methods}

\section{Study area}

The study area is located in the north-west part of the Iberian Peninsula and is comprised of the catchments of the Cega and Pirón Rivers within the Duero River basin (Figure 1a). Both are small Mediterranean rivers with a pluvio-nival hydrological regime, presenting severe droughts in the summer. The Cega River has a total length of $149 \mathrm{~km}$, drains an area of $2579 \mathrm{~km}^{2}$ and flows mainly from south to north presenting an average total annual discharge of $232.1 \mathrm{hm}^{3}$ (CHD 2009). Its main tributary is the Pirón River with a length of $98 \mathrm{~km}$, a basin area of $1024 \mathrm{~km}^{2}$ and an average annual discharge of $74 \mathrm{hm}^{3}$. The flow regime in the Cega River is not regulated. The Pirón River is regulated and affected by a major loss of longitudinal connectivity due to the presence of the Torrecaballeros Dam (height $26 \mathrm{~m}$; capacity $0.324 \mathrm{hm}^{3}$ ) in its headwaters (see Figures $1 a$ and $b$ ). 
Fish communities in the catchments of the Cega and Pirón Rivers are dominated by brown trout, Salmo trutta (density 12.2 ind. ha ${ }^{-1}, 44 \%$ out of the density of the fish community). Three rheophyllic cyprinids are the sub-dominant species: bermejuela, Achondrostoma arcasii (8.1 ind. ha $\left.{ }^{-1}, 30 \%\right)$; Northern Iberian chub, Squalius carolitertii (3.6 ind. ha ${ }^{-1}, 13 \%$ ); and Iberian gudgeon, Gobio lozanoi (3.3 ind. ha ${ }^{-1}, 12 \%$ ). The Iberian barbel, Luciobarbus bocagei (0.13 ind. ha $\left.{ }^{-1}, 0.5 \%\right)$, spined loach, Cobitis calderoni $(0.05$ ind. ha $\left.{ }^{-1}, 0.2 \%\right)$, and tench, Tinca tinca $\left(0.01\right.$ ind. ha $\left.{ }^{-1}, 0.04 \%\right)$ are the accompanying species (Junta de Castilla y León, 1997).

These species are common to both rivers, except for the Iberian barbel, which only appears in the Cega River, and the common carp (Cyprinus carpio), which is found only in the Pirón. The distributional pattern along the longitudinal gradient (upstream to downstream) is very similar in both rivers: trout - chub/nase - bermejuela - spined loach - barbel/gudgeon in the case of the Cega River, and trout - bermejuela/chub nase - spined loach/gudgeon - carp for the Pirón River.

We studied connectivity by focusing on the requirements of the fish communities of the Cega and Pirón Rivers. The overall connectivity depends on the passability values of each obstacle and the ability of fish species to cross them both upstream and downstream.

\section{Inventory of barriers}

To determine the overall connectivity of the Cega and Pirón river network, we developed an inventory of all artificial alterations to the longitudinal river continuity based on aerial photographs of the rivers. A total of 22 obstacles were detected, including large dams, weirs and other barriers, in the Cega and 20 were found in the Pirón (González Fernández et al., 2010; CHD 2009). Tributaries of both rivers were also affected by obstacles: 11 additional obstacles were found in the Cega catchment and 14 in the Pirón sub-catchment, resulting in a total set of 67 obstacles for the entire river network (see Figure 1b). 

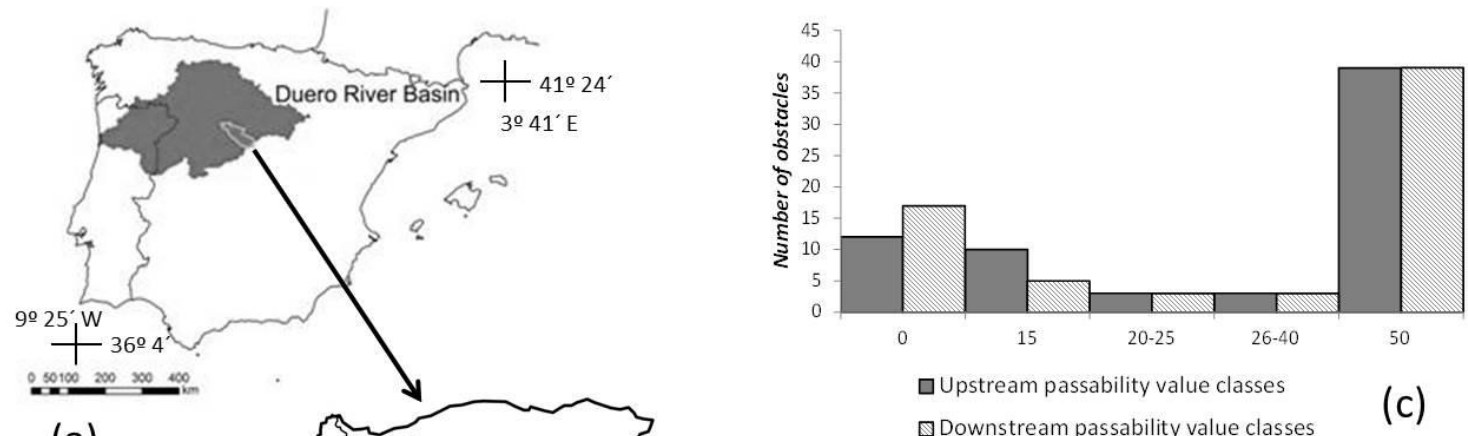

(a)

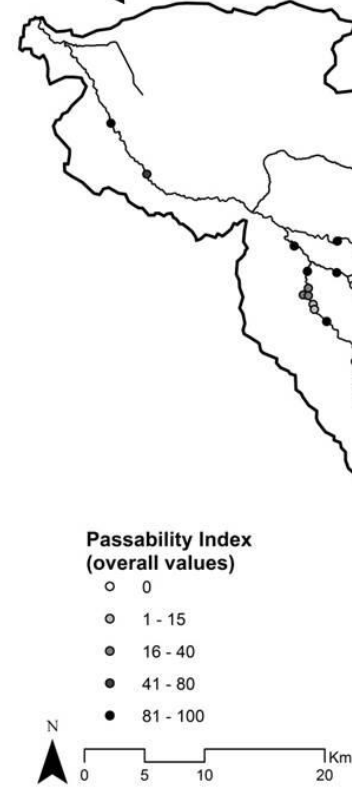

$\square$ Downstream passability value classes

(c)

(b)

Fig. 1 (a) Map of the Duero River basin located on the Iberian Peninsula. (b) The Cega and Pirón River basin. Black points in this figure represent artificial barriers in the fluvial network. (c) Number of obstacles in the river network based on their upstream and downstream passability values.

\section{Fish passability values}

The concept of barrier passability is difficult to define (though a rough definition could be a barrier's capability of being passed). However, there are many methods for estimating passability (Bourne et al., 2011). The passability of an obstacle must be analysed according to the attributes of each barrier and the requirements and possibilities of passage of each fish species in both directions (Cote et al 2009; Bourne et al., 2011; Januchowski-Hartley et al., 2013). However, there is some uncertainty surrounding this concept due to the difficulty in estimating the mean passability of a dam for a fish species. Mean passability is linked to fish physiology, which may vary depending not only on the species but on the size and other individual traits. Additionally, the attributes of the barriers change depending on the flow conditions (Bjornn and Peery, 1992), affecting the actual fish passability. 
To determine the passability of the Cega and Pirón river network barriers, we have relied on the study "Diagnosis of longitudinal connectivity in Duero River Basin" (González Fernández et al., 2010, not published) where a passability index is developed. This index ranges from 0 to 100: the higher the probability to cross, the lower the index value (Figure 1c). We consider that this definition is not intuitive so we have define a passability probability value, named Connectivity Index (hereafter $\mathrm{Cl}$ ) which reflects the chance that a fish passes through the dam in both senses: upstream and downstream. This $\mathrm{Cl}$ is a positive number, smaller than one, and is inversely proportional to the passability index which González Fernández et al. (2010) defined. In particular, upstream Cls mainly depend on dam wall height, dam wall upper sill, dam wall slope, downstream ponds, fish passage structures and hydraulic features (i.e. flow, upstream and downstream depth, water velocity, water temperature, water jet streams), whereas downstream Cls are mainly related to the probability of fish straying in big dams and the features of spillways, water inlets, conduction pipes and water connections, among other factors. Once the main dam physical parameters were measured, the fish species that live in the river were clustered into five groups according to their swimming performance and migratory life tactics: (1) fish species with high swimming and jump capacity, i.e. salmonids like Salmo trutta, (2) fish species of cyprinids with high swimming and low jump capacity, i.e. migratory cyprinids like Luciobarbus bocagei, (3) fish species of cyprinids with moderate movement and low jump capacity, i.e. small migratory cyprinids like Gobio lozanoi, (4) slow water fish with no ability to jump like Tinca tinca and (5) benthonic fish like Cobitis calderoni. After calculating the upstream and downstream passability values for each barrier, a graph was developed as described in next section.

\section{Estimating the connectivity loss by dams}

In order to quantify the loss of connectivity in these rivers due to the presence of potential barriers, we used an approach based on graph theory (Erös et al., 2011, 2012; Segurado et al., 2013, 2014). We represented the Cega and Pirón river network as a graph (Figure 2). Then, we modelled the effects of obstacles on the longitudinal connectivity of these rivers. For the hydrological modelling of freshwater bodies, it is useful to consider the stream segments as nodes. In this methodological approach, each river segment (node) has some amount of associated habitat, which is represented here as a combination of the length and mean width of the segment. Then, these segments are joined by links or connectors with different strengths (passabilities) that can be headwaters, confluences (river junctions), river mouth and 
transversal obstacles (dams and weirs). These elements are considered to be connectors because they determine the connection of each river segment to the previous and subsequent ones.

In addition, each link between river segments has a probability value $(\mathrm{Cl})$ that reflects the chance that a fish passes through the connector. In the graph (Figure 2), the junction of two river segments will have full probability of movement; the $\mathrm{Cl}$ will be 1. However, if the segment is limited by an insurmountable barrier, then the $\mathrm{Cl}$ value will be 0 , which means that there will be no possibility to cross and therefore the segments will be disconnected (see Table 1).

Table 1 Data on 20 connectors, including (1) the fluvial network to which they belong, (2) the connector number, $(3)$ the probability of passability $(\mathrm{Cl})$ in both directions of each connector.

\begin{tabular}{|c|c|c|c|}
\hline \multirow{2}{*}{$\begin{array}{l}\text { River } \\
\text { basin }\end{array}$} & \multirow{2}{*}{$\begin{array}{c}\text { Connector } \\
\text { number }\end{array}$} & \multicolumn{2}{|c|}{ Passability probability (Cl) } \\
\hline & & $\begin{array}{c}\text { Upstream } \\
\text { (Cl up.) }\end{array}$ & $\begin{array}{c}\text { Downstream } \\
\text { (Cl down.) }\end{array}$ \\
\hline \multirow{10}{*}{ Cega } & 2 & 1 & 1 \\
\hline & 3 & 1 & 1 \\
\hline & 4 & 0 & 0 \\
\hline & 5 & 0.2 & 0.4 \\
\hline & 22 & 0 & 0 \\
\hline & 28 & 1 & 1 \\
\hline & 29 & 0 & 0 \\
\hline & 48 & 0 & 0 \\
\hline & 49 & 0.2 & 0.2 \\
\hline & 53 & 0 & 0 \\
\hline \multirow{10}{*}{ Pirón } & 55 & 0 & 0 \\
\hline & 59 & 0.7 & 0.7 \\
\hline & 60 & 0.6 & 0.6 \\
\hline & 66 & 0.7 & 0.7 \\
\hline & 67 & 0.7 & 0.7 \\
\hline & 68 & 0.7 & 0.7 \\
\hline & 78 & 0 & 0.2 \\
\hline & 79 & 0.7 & 0.6 \\
\hline & 100 & 0.7 & 0.7 \\
\hline & 102 & 0.2 & 0.5 \\
\hline
\end{tabular}




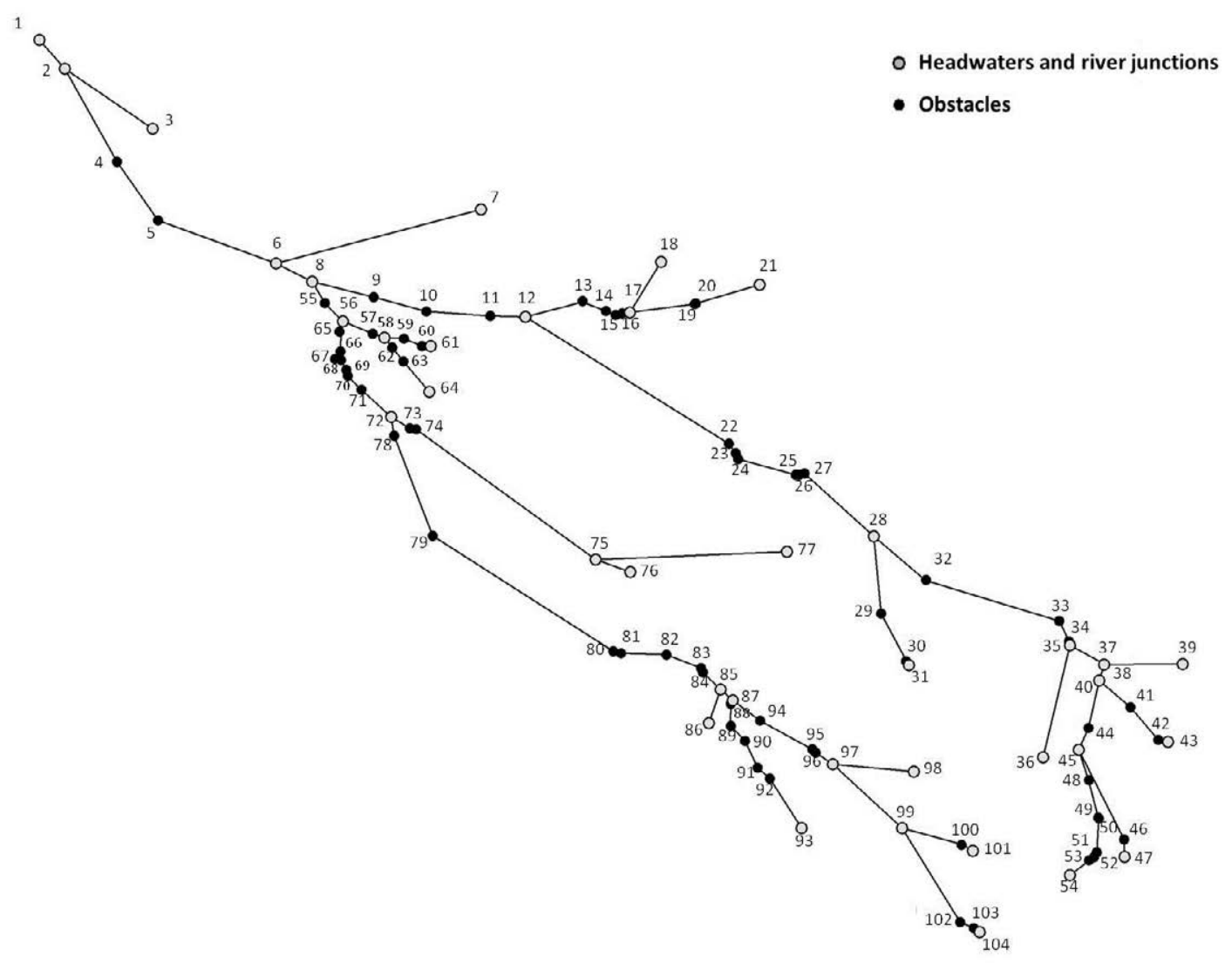

Fig. 2 Graph representation of the Cega and Pirón river network. Grey circles represent headwaters and joints between two watercourses, whereas black circles represent barriers. Each river segment is delimited by two numbered connectors.

Once the graph is built and each node and link are characterised, the relevance of each particular node and link for the overall connectivity of the basin is calculated. To measure the overall connectivity of the whole river system, we used the Probability of Connectivity index (PC) (Saura and Pascual-Hortal, 2007), which allows for modulating the passability of each particular obstacle in a continuous range from 0 to 1 . The results of the PC were also compared to those provided by the Integral Index of Connectivity (IIC) (Pascual-Hortal and Saura, 2006), which has been used in previous studies related to river networks (Segurado et al., 2013, Erös et al., 2011) and only allows for including either full barriers or fully permeable junctions along the river network. The IIC is a connection index based on a binary system by which two habitat patches are either connected or disconnected without intermediate modulation of the strength of the connection between both patches and viability of dispersion (Figure 3). The PC and IIC increase with higher connectivity and range from 0 to 1 . Both are also topo-ecological indices, i.e. they account for the attributes of the habitat patches along with the topological relationships between those patches within the network (Saura and Rubio, 2010). The two connectivity indices (both the PC and the IIC) were 
calculated using the software package Conefor (Saura and Torné, 2009; available at www.conefor.org). Furthermore, the PC for asymmetric graphs was computed using a purposefully developed version of the Conefor command line (available under request to authors).

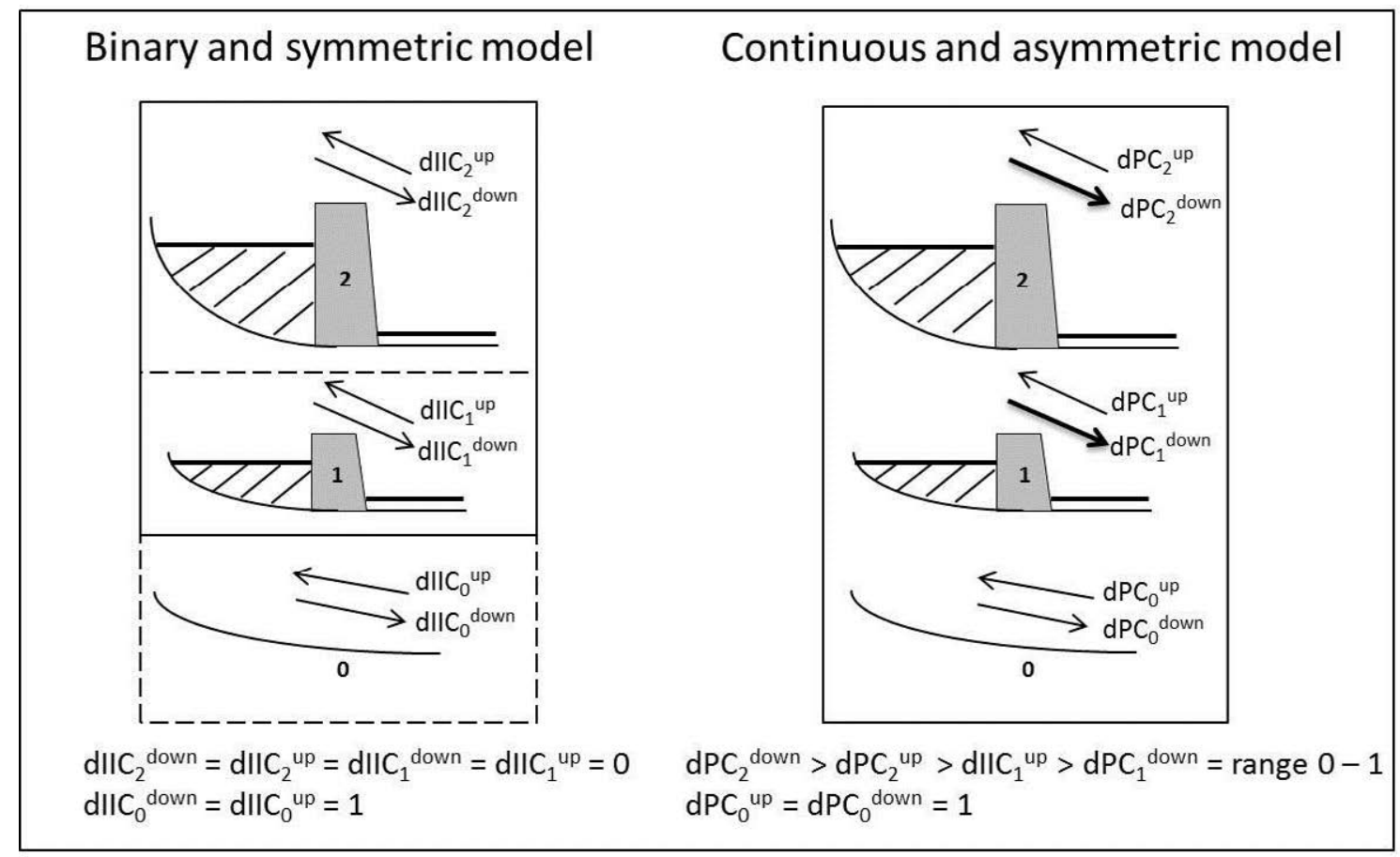

Fig. 3 Schematic comparison between the results of applying the IIC and PC indices to different river scenarios. A simple visual representation of the three possible connectivity situations in the rivers is shown: a river in natural conditions without obstacles $(0)$, small weirs that can be assumed to be a hindrance to connectivity depending on some different attributes (fish species, river flow and physical characteristics of the obstacle) (1), and big dams that generate disruption to the river connectivity (2). The left side shows the results of the application of dIIC whereas the $\mathrm{dPC}$ results are shown on the right.

Application of habitat availability indices to prioritise connectivity conservation and/or improvement

The contribution of each node or river segment to the overall connectivity was assessed by calculating the percent variation in the values of the indices after removal of that particular segment from the river network ( $\mathrm{dIIC}$ and $\mathrm{dPC}$, where $d$ means the percentage of the variation). The contribution of landscape elements (in this case, river segments) to the overall connectivity can be divided into the sum of three sub-indices: intra, flux and connector (Saura and Rubio, 2010). 
The intra fraction represents the intrapatch connectivity (habitat resources that can be reached within a given segment, without moving to other segments). This fraction is independent of how a node is connected with the others. The flux fraction reflects how well connected a segment is to the rest of the habitat segments in the river network. The connector fraction represents how important a given segment is for maintaining the rest of the habitat segments connected to each other. For this reason, this fraction is particularly relevant to this study due to the special characteristic of river systems: one single path of movement (the river stream) without other possible alternative paths making these ecosystems exceptionally vulnerable to fragmentation (Erös and Grant, 2015). This feature of river systems is what makes the connector fraction essential, acting as a bridge patch or "stepping stone".

On the other hand, evaluating the contribution of each link allows us to determine the effects on the connectivity of the removal of an obstacle (dam or weir). This feature was assessed by recalculating the connectivity indices, considering that a given link is fully passable (no restrictions on movement between two particular segments). In the probabilistic model of the PC, this translates as the connection between segments having a probability equal to 1 of conducting movement, i.e. the probability of circulation between two pairs of segments will be 1 rather than the resistance value it had before. In a riverine network, we only consider the pairs of segments with a direct connection between them. Calculations were performed using the "link improvement" functionality of the Conefor software package (Saura and Torné, 2012).

\section{Determining the reliability of considering the river as a symmetric model}

In order to test the effectiveness of using an asymmetrical version of PC versus the symmetrical one used in previous studies, we compared both indices through the generation of two different scenarios with different movement characteristics: 1) a scenario where downstream passability is only considered, and then all barriers are impassible for the upstream movement and totally passable for the downstream movement and 2) a scenario where upstream passability is only considered, with inverse conditions to the previous scenario. 


\section{Results}

Converting the fluvial system into a graph

In the absence of obstacles, the graph depiction would be comprised of the river segments linked by the junctions of the main river and its tributaries. By adding the dams and weirs, the number of segments in the graph rises from 38 to 104 (Figure 2). According to the $\mathrm{Cl}$ values, the number of impassable obstacles in both directions for the Cega River and its tributaries reaches 21, while for the Pirón, it is 17 . The remaining obstacles in the Cega River are considered easy to overcome because, except for three cases, they possess $\mathrm{Cl}$ values between 1 and 0.7. In the Pirón River nine obstacles with $\mathrm{Cl}$ values between 0.7 and 0.6 are found.

\section{Application of connectivity indices to the fluvial basin}

Both the IIC and the PC indices have determined which of the river segments are the most sensitive to the loss of connectivity and thus, are more valuable for removing or permeabilising dams (Figure 4). The values of the connector fraction and the position on the ranking of influence for the overall connectivity differ when one or the other index is applied. These differences are a result of both the positions of the nodes in the network and of the characteristics of the barriers or links among them. The dIIC and dPC ranking results were substantially different for the same segment: only $45 \%$ of the barriers are coincident in both approaches. The lowest dPC values were found in segments located in the upper reaches of small streams or near an insurmountable obstacle that prevents the movement of fish species. On the other hand, the highest values were found in the lower reach, where the Pirón meets the Cega, in the Cega main watercourse and in the segments with fewer obstacles. The contribution of each river segment, measured by the IIC and PC, is shown in Figure 3. In the case of the dIIC, $60 \%$ of the 20 most important connectors corresponded to river segments that were limited by insurmountable barriers, whereas in the case of the $\mathrm{dPC}$, only a $35 \%$ of the segments are limited by barriers that are totally insurmountable in both directions. This means that, in this case, considering the IIC index instead of the PC, the loss of connectivity has been overestimated. 

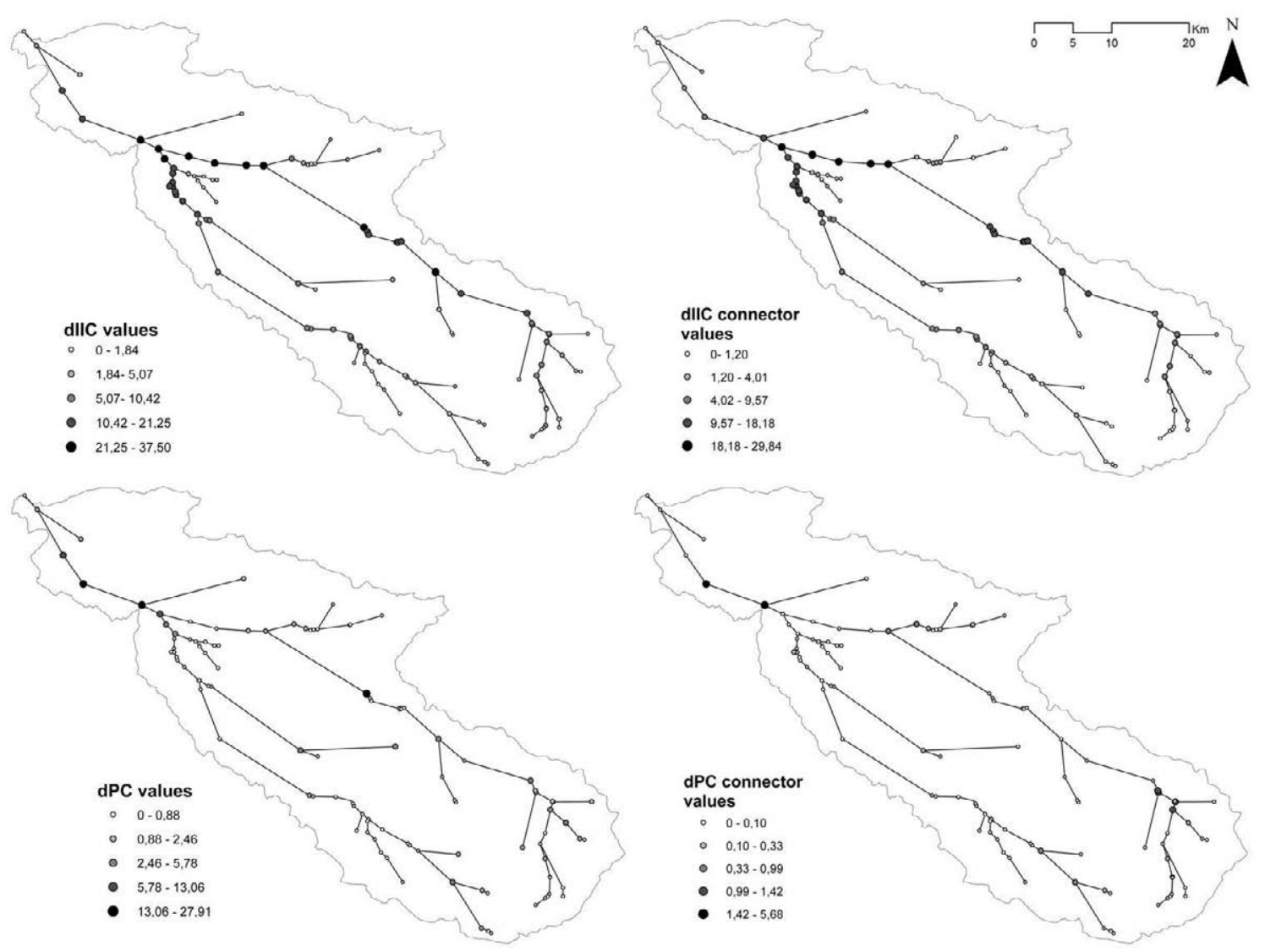

Fig. 4 Graph-based representation of the Cega and Pirón Rivers using the dIIC and dPC indices and their corresponding connection fraction. The darkest circles represent elements with high connectivity values and thus are targets for conservation

With respect to the results of the connector fraction, we can define which river segments need to be prioritised, i.e. those where it is critical to keep high levels of connectivity throughout the river. In this case, when the dIICconnector was applied, $55 \%$ of the segments were limited by insurmountable barriers, while the percentage was reduced to $5 \%$ when using the dPCconnector. In the case of the dPCconnector, the connectors with high values are located at the confluence of the waterways, as shown in Figure 4; for that reason, they are characterised as being especially important in the conservation of these river networks.

The application of the link improvement procedure generated a ranking of the barriers that hinder fluvial continuity. This ranking determines that connector 55 is the major disruptor in connectivity, followed by connectors $22,5,4,37$ and 9 . This is a consequence of the strategic topological position of these barriers in the network, mostly in the downstream sections or in the junctions among important segments, generating a disconnection with the upper reaches of the river. 
Results from the application of the symmetric and the asymmetric versions of PC suggest important differences between both versions, highlighting that a symmetric passability should not be assumed in connectivity studies for river systems. While the differences in the ranking are limited so that the first nine segments are equal in both cases, the results of the connector fraction differ between both symmetric and asymmetric approaches (Table 2). The difference between the dPC values when considering symmetric and asymmetric passability is around 9\%, evaluated through the sum of the differences. In the connector fraction, this sum rises to $24.89 \%$. In this particular case, the majority of the obstacles have a symmetric passability. The sum of the differences between the upstream $\mathrm{Cl}$ and downstream $\mathrm{Cl}$ values is around $6.7 \%$ of the mean values of both Cls.

Table 2 Comparison of $\mathrm{dPC}$ and $\mathrm{dPC}$ connector values in the study area using different versions of the PC index (symmetric versus asymmetric) for the 20 most important connectors. Each column contains the number of the connector, ordered according to its importance in the overall connectivity. Black arrows represent correspondence between the connectors in both models.

\begin{tabular}{|c|c|c|c|}
\hline \multicolumn{2}{|c|}{ PC } & \multicolumn{2}{|c|}{ dPCconnector } \\
\hline symmetric & asymmetric & symmetric & asymmetric \\
\hline 6 & $\rightarrow 6$ & 6 & $>6$ \\
\hline $22-$ & $\rightarrow 22$ & 5 & $\rightarrow 5$ \\
\hline 5 & $\rightarrow 5$ & 40 & 738 \\
\hline 8 & $\rightarrow 8$ & 38 & 40 \\
\hline 4 & $\rightarrow 4$ & 35 & 35 \\
\hline $75-$ & $\rightarrow 75$ & 34 & $\rightarrow 34$ \\
\hline 28 & $\rightarrow 28$ & 41 & 12 \\
\hline 77 & $\rightarrow 77$ & 12 & 99 \\
\hline 33 & $\rightarrow 33$ & 99 & 97 \\
\hline 40 & & 13 & \\
\hline 56 & 99 & 42 & 75 \\
\hline 99 & 34 & 75 & 20 \\
\hline 41 & $1^{13}$ & 2 & 17 \\
\hline $34^{\prime}$ & & 14 & $\begin{array}{l}14 \\
48\end{array}$ \\
\hline 48 & 40 & 68 & $>68$ \\
\hline $13^{\prime}$ & 11 & $67-$ & 50 \\
\hline $80^{\prime}$ & 36 & 58 & 67 \\
\hline $12^{\prime}$ & 7 & 19 & 58 \\
\hline
\end{tabular}


The differences between the asymmetric and the symmetric perspectives are emphasised in the case of upstream connectivity (20 major differences vs. 14 in the case of downstream connectivity) (Figure 5). Normally, the symmetric index overestimates the importance of the connector (yellow circles), except for five connectors of the middle reach of the river (the orange circles 22, 28, 33, 75 and 77), in which the dPCconnector for the asymmetric network exceeds the value of the symmetric case.

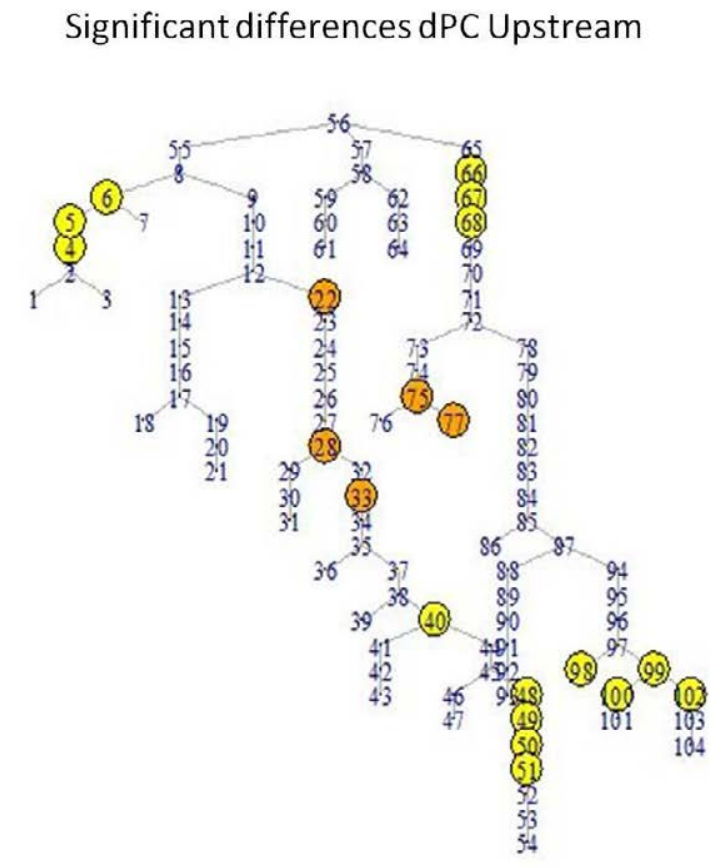

Symmetric_UP > Asymmetric_UP (yellow)
Significant differences dPC Downstream

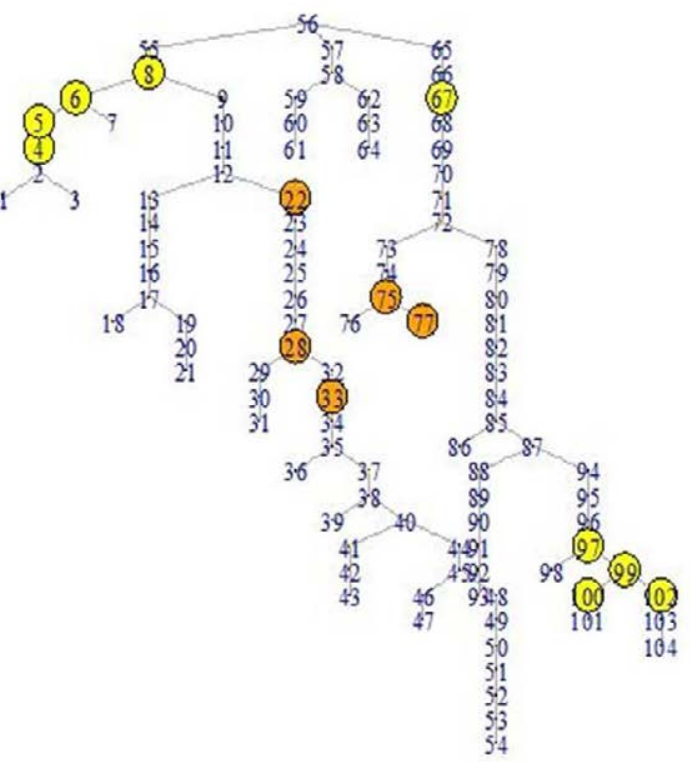

Symmetric_DOWN > Asymmetric_DOWN (yellow)

Fig. 5 Graph representation of the major differences between the symmetric and the asymmetric models for upstream and downstream movement. The circled numbers represents important differences. Yellow filled circles imply an overestimation of the symmetric version versus the asymmetric one, while orange filled circles represent an underestimation.

A pair of graphics has been developed to represent differences in the use of the $\mathrm{dPC}$ index from upstream and downstream passability (Figure 6). Higher overweights in the symmetric indicator are found in the downstream connectors, specifically in numbers 6, 5, 4, 99 and 102 (yellow). In connector 22, the asymmetric index has a higher value than does the symmetric (orange circle), indicating a higher level of importance of this element. Regarding upstream connectivity, the pattern is similar: an overweight of the symmetric indicator for connectors 6, 5, 4, 48, 49, 99, 100 and 102, but with a lower bias (i.e. smaller absolute value). The dPC value of connector 22 is 
smaller in the asymmetric analysis. However, this difference is smaller compared in this upstream direction than in the downstream one (Figures 6a. and b.).

The graph model was evaluated to determine the importance of the connectors according to their dPC upstream value. We observed that the most important barriers/links are connectors 5, 6 and 8, where an asymmetry exists in the probability of passability. On the other hand, connector 22 has a high value but its probability of passability upstream and downstream is symmetric. It is noticeable that among the main connectors, both barriers (i.e. 22 with a value of 20.6 or 5 with 16.5) and river junctions (i.e. 6 with a value of 27.3 ; 8 with 13.2; 75 with 6.2 or 28 with 5.2 ) are included.

It seems that the number of overestimations is lower in the asymmetric model (32 yellow circles against 72 in orange). It is also interesting that in the lower part of the basin, overestimation of the importance calculated by the symmetrical method is more common, while in the upper reaches underestimation of the node importance is more frequent (i.e. in the figure, orange nodes are more abundant) (Figures 6c. and d.). 


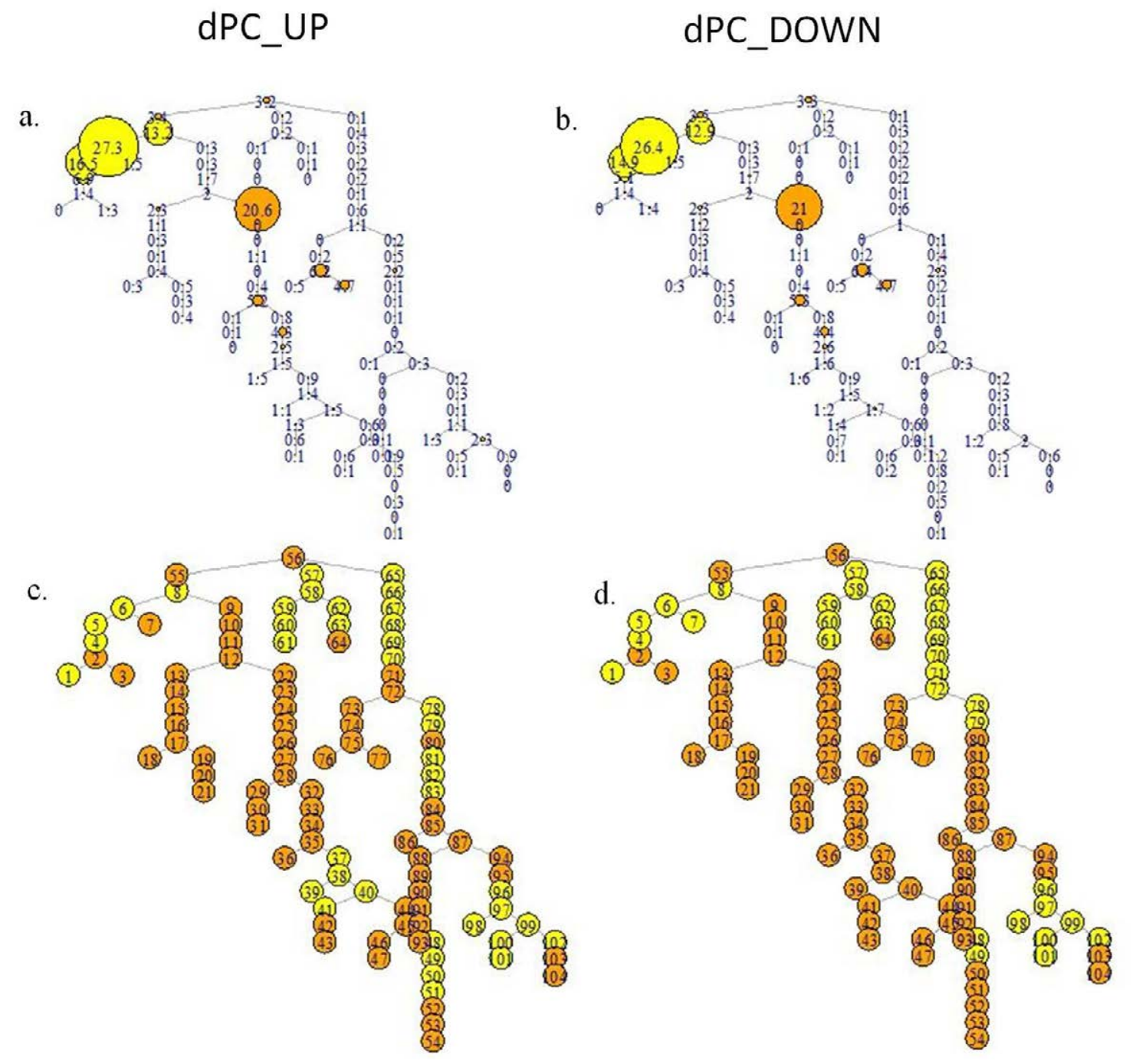

Fig. 6 Graph representation of the differences between the upstream and downstream passability using the $\mathrm{dPC}$ index. Charts $a$. and $b$. represent a bubble diagram where maximum variations among the results by using symmetric and asymmetric models are shown. Charts $\mathrm{c}$. and $d$. show the type of bias on the symmetric model assessment: overestimation (yellow) and underestimation (orange).

\section{Discussion}

This study supports the view that graph-based methodologies are effective tools for identifying the obstacles that make the greatest contributions to the overall loss of longitudinal connectivity in rivers. Moreover, these methods can help prioritise the river segments to be protected or restored. The graph model of the basin simplifies the study of the river network and the attributes, as well as the location of the diverse barriers on it. 
The aim of this research coincides with previous studies of longitudinal connectivity in freshwater ecosystems, but differs from them in the asymmetric implementation of the graph-based approach. In this study, connectors associated with passability values separated the nodes. We consider that our model provides more accurate information about the behaviour of a dendritic stream network by providing data about the location and permeability value of the barriers.

Our analysis reveals the importance of considering downstream sections as target elements for conservation due to their relevance in maintaining the connectivity of upstream segments (Cote et al., 2009, Erös et al., 2011). However, since we have here evaluated $\mathrm{dPC}$ characterizing river segments by their habitat extension (namely, total wet area), the importance of segments we have obtained might be biased towards those located in the lower, wider reaches. This bias can be corrected by considering the reach length, instead of the area, as the proxy of the habitat attribute that is assigned to every node in the calculation of the PC metric (Cote et al., 2009).

Connectivity is likely non-additive (O'Hanley and Tomberlin, 2005, O'Hanley 2011), that is, the impact of removing many clusters of dams is not necessarily equivalent to the sum of the impact of removing individual obstacles separately. However, the approach and tools used in this research are equally applicable for evaluating the cumulative effect of removing several obstacles at a time.

Considering a continuous range of passability values rather than treating all obstacles as full or no barriers

Saura and Pascual-Hortal (2007) suggested the application of IIC and PC among the existing indices used to calculate ecological connectivity. Between those two indices, they recommend the application of the PC because the IIC can generate an oversimplified representation of connections between nodes due to the fact that the barriers are classified either as completely insurmountable or completely surmountable, in contrast to the probabilistic approach provided by the PC index.

The observed ranking differences between the dllCconnector and dPCconnector are caused by the different connectivity models on which each of them relies (binary against probabilistic connections) (Baranyi et al., 2011). The dIIC ranking values present important differences regarding $\mathrm{dPC}$ values (see Results section) because of the characteristics of each index: the IIC gives more value to the impassability of the barriers, while the PC values give more importance to the position 
of the dam in the fluvial network, beyond a simplified consideration of whether or not a given obstacle is impassable.

In this case, the PC index is required because some of the obstacles in the case study rivers are not absolutely insurmountable, depending on the physical characteristics of the obstacle and the biology of the chosen fish species. Therefore, it is important that the classification of the obstacles is not reduced to only being insurmountable or surmountable, but that it also possesses intermediate values, depending on the analysed parameters. Another important aspect is that the ability of the fish species to pass barriers must be measured in two ways, upstream and downstream. The $\mathrm{Cl}$ provides passability values for each obstacle, allowing us to determine the probabilities of crossing every barrier in both directions for the selected species and thus allowing for the generation of a bidirectional graph. Then, only the PC index enables the consideration of this asymmetrical characteristic.

\section{Asymmetric model vs. symmetric model}

Traditionally, when it is established that both directions are equally important in determining the overall connectivity of river networks, downstream passability receives less attention than does the upstream one (González Fernández et al., 2010). The importance of asymmetry of movement in dendritic systems (Padgham and Webb, 2010, Grant 2011) is a relevant condition to apply an asymmetric graph resolution to prioritise barriers that suppose an obstacle for species movement. If a single passability value is assigned to quantify the relevance of an obstacle, symmetric passability is assumed. In this work, this assumption is avoided by considering different passability values in those obstacles where movement is easier in one direction than in the other. To assess the importance of neglecting the asymmetric passability of obstacles in these studies, the results of both approaches were compared. After comparing the results from both approaches (Table 2), the ranking of obstacles according to the $\mathrm{dPC}$ in both models is congruent for the most important obstacles but not for all of them. In the connector fraction, a higher variability between the models can be observed in the connector ranking.

When analysing passability in the asymmetrical model, it was found that upstream and downstream values were similar in most of the cases (see Figure 1c). Therefore, it appears that symmetric passabilities can be assumed. However, while the mean difference between the downstream and upstream $\mathrm{Cl}$ is small, the asymmetric model was found to be helpful for improving the downstream passability in some 
cases. Both models are really useful, but the asymmetric model is useful to refine the model and evaluate more subtle changes in connectivity. The asymmetric model may be especially useful for analysing clusters of close barriers because of the differences in their passability due to flow conditions. While the asymmetric model may be preferable in networks with small obstacles, the symmetric model may be useful in rivers with large insurmountable dams. Although the barrier ranking was rather similar for both the symmetric and asymmetric models, the prioritisation of conservation measures depends on more parameters, i.e. actuations on small barriers with different levels of passability located in headwaters could be more cost-effective than the elimination of a large dam.

The asymmetrical methodological framework distinguished between some barriers whose downstream passability might be increased by soft actions from other barriers where their upstream passability will only be increased by the implementation of more budget-demanding measures, such as hard fish passage constructions or dam wall demolitions.

\section{Further research}

The assumption of symmetric passabilites may not always be affordable (Baranyi et al., 2011). Previous studies of fluvial connectivity (Erös et al., 2011; Segurado et al., 2013, 2014) have only considered the ranking of river segments to prioritise those that maintain river connectivity, while the study of links (named connectors in this research) has received little attention. Conefor can calculate the link importance by means of the link improvement tool, which creates a rank of barriers that suppose a hindrance to connectivity. This tool allows the decision makers to establish priorities in dam management by providing information on improvement of the connectivity when each obstacle is eliminated relative to the current situation (Bednarek 2001). An extension of this application that includes dam placement in the riverine network, the height and the material with which dams are built may lead to a more realistic model of connectivity in which differential passability plays a crucial role. We consider that further research on this area should be conducted.

Climate change prospects may increase water storage necessities and the pressure to build more dams (Oki and Kanae, 2006), increasing habitat fragmentation and threatening important segments that maintain river connectivity (Rahel and Olden, 2008). Mediterranean rivers are especially fragile to fragmentation produced by water scarcity. For that reason, we consider it essential to study these types of rivers 
because they will be particularly affected in the future by climate change predictions (Santiago et al., 2015). In this situation of increasing water scarcity, measures to wisely conciliate human exploitation and river conservation become essential for ensuring the structure and functions of healthy ecosystems.

\section{Acknowledgments}

Part of this study has been supported by $7^{\text {th }}$ Framework Programme of the European Union (DURERO Project C1 3913442). We thank Gustavo González and his team for the valuable information about connectivity and barrier passability in the Duero River Basin. We would like to express our thanks to Pablo Moreno and Vanesa MartínezFernández for their comments which improved the quality of the paper. Two anonymous reviewers are thanked for their helpful comments and insights.

\section{References}

Baranyi G, Saura S, Podani J, Jordán F. 2011. Contribution of habitat patches to network connectivity: redundancy and uniqueness of topological indices. Ecol Indic 11:1301-1310

Bednarek AT. 2001. Undamming rivers: a review of the ecological impacts of dam removal. Environmental Management 27(6): 803-814.

Bjornn TC, Peery CA. 1992. A review of literature related to movements of adult salmon and steelhead past dams and through reservoirs in the Lower Snake River. Technical Report 92-1, US Fish and Wildlife Service, Idaho Cooperative Fish and Wildlife Research Unit, University of Idaho, Moscow.

Bodin Ö. 2009. Ecological topology and networks. Meyers, S. (Ed.), Encyclopedia of Complexity and System Science. Springer, New York, pp. 2728-2744

Bodin Ö, Saura S. 2010. Ranking individual patches as connectivity providers: integrating network analysis and patch removal experiments. Ecological Modelling 221:2393-2405.

Bourne CM, Kehler DG, Wiersma YF, Cote D. 2011. Barriers to fish passage and barriers to fish passage assessments: the impact of assessment methods and assumptions on barrier identification and quantification of watershed connectivity. Aquat Ecol 45: 389-403.

Branco P, Segurado P, Santos JM, Pinheiro P, Ferreirs MT. 2012. Does longitudinal connectivity loss affect the distribution of freshwater fish? Ecol Eng 48:70-78

Calabrese JM, Fagan WF. 2004. A comparison shoppers' guide to connectivity metrics: trading of between data requirement and information content. Front Ecol Environ 2:529-536 
Carranza ML, D'Alessandro E, Saura S, Loy A. 2012. Connectivity providers for semiaquatic vertebrates: the case of the endangered otter in Italy. Landscape Ecology 27: 281-290.

CHD. 2009. Plan hidrológico del Duero. Plan hidrológico de la parte española de la demarcación hidrográfica del Duero propuesta de proyecto de plan hidrológico de cuenca. España.

Cote D, Kehler DG, Bourne C, Wiersma YF. 2009. A new measure of longitudinal connectivity for stream networks. Landscape Ecol 24:101-113

Erös T, Schmera D, Schick RS. 2011. Network thinking in riverscape conservation - A graph-based approach. Biol Conserv 144:184-192

Erös T, Olden JD, Schick RS, Schmera D, Fortin M-J. 2012. Characterizing connectivity relationships in freshwaters using patch-based graphs. Landscape Ecol 27:303317

Erös T, Grant, EHC. 2015. Unifying research on the fragmentation of terrestrial and aquatic habitats: patches, connectivity and the matrix in riverscapes. Freshwater Biology, 60(8), 1487-1501.

González Fernández G, Pérez Cardenal D, Miguelez Carbajo D, Gallego García R, Fernández Suárez R, Álvarez Durango E, Canal Rubio P, Roa Álvarez I, Rosa Cubo E, Seisdedos Fidalgo P. 2010. Diagnóstico de la conectividad longitudinal en la Cuenca del Duero. Ministerio de Medio Ambiente, Medio Rural y Marino. Available in http://www.chduero.es/acciona5/metodologia/ic.pdf

Gough P, Philipsen P, Schollema PP, Wanningen H. 2012. From sea to source: International guidance for the restoration of fish migration highways. Regional Water Authority Hunze en Aa's. The Netherlands.

Grant EHC, Lowe WH, Fagan WF. 2007. Living in the branches: population dynamics and ecological processes in dendritic networks. Ecology Letters, 10(2), 165-175.

Grant EHC. 2011. Structural complexity, movement bias, and metapopulation extinction risk in dendritic ecological networks. Journal of the North American Benthological Society, 30(1), 252-258.

Hilty JA, Lidicker Jr WZ, Merenlender A. 2012. Corridor ecology: the science and practice of linking landscapes for biodiversity conservation. Island Press.

Januchowski-Hartley SR, McIntyre PB, Diebel M, Doran PJ, Infante DM, Joseph C, Allan JD. 2013. Restoring aquatic ecosystem connectivity requires expanding inventories of both dams and road crossings. Front Ecol Environ. 11(4), 211-217

Junta de Castilla y León. 1997. Estudio de las poblaciones piscícolas del río Cega (Segovia). Technical Report: Estudios Biológicos, Madrid.

Junta de Castilla y León. 1998. Segundo muestreo piscícola en la cuenca del río Cega (Segovia). Technical Report (unpublished): Estudios Biológicos, Madrid. 
Kondolf GM, Boulton AJ, O'Daniel S, Poole GC, Rahel FJ, Stanley EH, Whol E, Bång A, Carlstrom J, Cristoni C, Huber H, Koljonen S, Louhi P, Nakamura K. 2006. Process-Based Ecological River Restoration: Visualizing Three-Dimensional Connectivity and Dynamic Vectors to Recover Lost Linkages. Ecology and Society $11(2): 5$

Lucas MC, Baras E, Thom TJ, Duncan A, Slavík O 2001. Migration of freshwater fishes (Vol. 47). Oxford: Blackwell Science.

Minor ES, Urban, DL. 2007. Graph theory as a proxy for spatially explicit population models in conservation planning. Ecol. Appl. 17:1771-1782.

Minor ES, Urban DL. 2008. A graph-theory framework for evaluating landscape connectivity and conservation planning. Conserv. Biol. 22:297-307.

Nicola GG, Elvira B, Almodovar A. 1996. Dams and fish passage facilities in the large rivers of Spain: effects on migratory species. Large Rivers 10, 375-379.

O'Hanley, JR. 2011. Open rivers: barrier removal planning and the restoration of freeflowing rivers. Journal of Environmental Management, 92(12), 3112-3120.

O'Hanley, JR, Tomberlin, D. 2005. Optimizing the removal of small fish passage barriers. Environmental Modeling \& Assessment, 10(2), 85-98.

Oki T, Kanae S. 2006. Global hydrological cycles and world water resources. Science, 313(5790), 1068-1072.

Padgham M, Webb JA. 2010. Multiple structural modifications to dendritic ecological networks produce simple responses. Ecological Modelling, 221(21), 2537-2545.

Pascual-Hortal L, Saura S. 2006. Comparison and development of new graph-based landscape connectivity indices: towards the priorization of habitat patches and corridors for conservation. Landscape Ecol. 21:959-967.

Rahel FJ, Olden JD. 2008. Assessing the effects of climate change on aquatic invasive species. Conserv. Biol. 22, 521-533.

Rivers-Moore N, Mantel S, Ramulifo P, Dallas H. 2016. A disconnectivity index for improving choices in managing protected areas for rivers. Aquatic Conservation: Marine and Freshwater Ecosystems, 26(S1), 29-38.

Santiago JM, García de Jalón D, Alonso C, Solana J, Ribalaygua J, Pórtoles J, Monjo R. 2015. Brown trout thermal niche and climate change: expected changes in the distribution of cold-water fish in central Spain. Ecohydrol.

Saura S, Pascual-Hortal L. 2007. A new habitat availability index to integrate connectivity in landscape conservation planning: comparison with existing indices and application to a case study. Landscape Urban Plan 83:91-103

Saura S, Rubio L. 2010. A common currency for the different ways in which patches and links can contribute to habitat availability and connectivity in the landscape. Ecography 33:523-537 
Saura S, Torné J. 2009. Conefor Sensinode 2.2: a software package for quantifying the importance of habitat patches for landscape connectivity. Environmental Modelling \& Software 24: 135-139.

Saura S, Torné J. 2012. Conefor 2.6 user manual (April 2012). Universidad Politécnica de Madrid. Available at www.conefor.org.

Schick RS, Lindley ST. 2007. Directed connectivity among fish populations in a riverine network. J Appl Ecol 44: 1116-1126

Segurado P, Branco P, Ferreira MT. 2013. Prioritizing restoration of structural connectivity in rivers: a graph based approach. Landscape Ecol 28:1231-1238.

Segurado P, Branco P, Avelar AP, Ferreira MT. 2014. Historical changes in the functional connectivity of river based on spatial networks analysis and the past occurrences of diadromous species in Portugal. Aquatic Sciences. 77(3), 427440.

Tockner K, Schiemer F, Ward JV. 1998. Conservation by restoration: the management concept for a river-floodplain system on the Danube River in Austria. Aquat Conserv 8:71-86.

Ward JV. 1989. The four-dimensional nature of the lotic ecosystem. Journal of the North American Benthological Society 8:2-8

Wiens JA. 2002. Riverine landscapes: taking landscape ecology into the water. Freshwater biology, 47(4), 501-515. 


\section{Chapter II}

"Be skeptical. But when you get proof, accept proof" Michael Specter 


\section{Using Fuzzy Cognitive Maps for predicting river management responses: A case study of the Esla River Basin, Spain}

This chapter reproduces entirely the paper published in:

Solana-Gutiérrez J, Rincón G, Alonso C, García de Jalón D. 2017. Using Fuzzy Cognitive Maps for predicting river management responses: A case study of the Esla River Basin, Spain. Ecological Modelling 360 (2017) 260-269.

\section{Abstract}

The planning and management of river ecosystems affects a variety of social groups (i.e., managers, stakeholders, professionals and users) who have different interests about water uses. To avoid conflicts and reach an environmentally sustainable management, various methods have been devised to enable the participation of these actors. Mathematical modelling of river systems is highly recommended to forecast, but we do not always have enough information to do it. In these cases, the soft and meta-models can be valid alternatives to simulate these complex systems.

The Fuzzy Cognitive Maps (FCMs) are presented as a tool that facilitates the modelling of ecological systems, functions and services. FCM networking concepts are intertwined through causal relationships. The FCM concept spatial arrangement and the use of fuzzy logic facilitates the integration of different expert opinions. In our study, from a panel of seven experts from representatives of different social sectors, an aggregated FCM was obtained. The most central concept in the aggregated map was cross barriers, dams and weirs. Using our FCM expert model, we performed a number of simulations from different possible scenarios, such as the continuous degradation of natural conditions and the improvement of river natural conditions. A regular increment in the the natural conditions generates a substantial enhance in variables as natural water flow and sediment transport. Conversely, the increment in human activities as agro-forestry production address to a deterioration of river banks among other variables.

In the Esla River, the FCM indicators showed an ecosystem that was greatly influenced by human activity, especially by the presence of barriers, in which the economic variables presented high network influence even though their centrality indices were relatively low. Meanwhile, the essential elements for the proper functioning of this ecosystem, as a natural flow regime, showed very low values that were visibly affected by anthropogenic variables. 
FCM methodology enabled us to not only understand the perception of current fluvial ecosystems but to also generate plausible management scenarios based on expert knowledge in this field.

Keywords: River management, Fuzzy Cognitive Maps, Ecosystem modelling, Simulation

\section{Introduction}

Mediterranean fluvial ecosystem has always been difficult to manage due to the large number of natural and human factors that affect them. Moreover, the pressure of human activities on these ecosystems has increased over time, reaching a point where most of these systems are highly degraded (Kauffman et al., 1997; Millennium Ecosystem Assessment, 2005; European Environmental Agency, 2012).

The outcomes of continuous human intervention in European rivers have caused a loss of function and environmental services (Elosegi et al., 2010). Thus, plans and actions regarding rivers not only affect natural and economic river resources, but also social assets (Millennium Ecosystem Assessment, 2005; Hommes et al., 2009). This legitimises the need for sustainable fluvial management and ecological restoration.

Frequently, various social actors present different scopes to address fluvial issues and contribute their different perceptions to assess and solve problems (Eshuis and Stuiver, 2005; Rinaudo and Garin, 2005). Therefore, to develop socially concerned and sustainable river practices, a participatory process should be established that, allows the stakeholders: (a) to work together to define the criteria for sustainable management, (b) evaluate alternatives, (c) set priorities and restrictions, (d) recommend technologies, (e) propose policies and ( $f$ ) monitor and evaluate impacts (Johnson et al., 2001; Giordano et al., 2005; Rinaudo and Garin, 2005).

To assist in the development of a river management plan based on both public participation and expert knowledge, we propose the use of Fuzzy Cognitive Maps (FCMs) as a semi-quantitative model tool as provides a structured, simple and inexpensive way to model overall fluvial systems through a soft evaluation of the relationship between different concepts and factors interpreted by stakeholders (Giordiano et al., 2005; Papageorgiou et al., 2009; Malek, 2017; Paolisso and Trombley, 2017).

Therefore, the present study aims to 1 ) explain the FCM as qualitative methods to model a fluvial system; 2 ) analyse the scope of expert knowledge in the development 
of multi-user decision-making models; and 3) apply the FCM in a case study of a Mediterranean fluvial management.

\section{Material and Methods}

\section{Fuzzy Cognitive Maps}

FCMs constitute a structured modelling technique that can be used in complex systems (Papageorgiou et al., 2009). Predictions on systems performance are made through a semi-quantitative or semantic assessment of the relationships between concepts (Papageorgiou and Kontogianni, 2012). A FCM can be described as a qualitative model that portrays how a given system operates (Özesmi and Özesmi, 2004). The qualitative model is derived by describing the system in terms of its component variables and the causalities among these variables (Park and Kim, 1995).

An FCM is a directed network (i.e., diagraph) composed of nodes or concepts that are used to describe system behaviour and edges that represent the causal links between concepts. Each concept (node) has a state variable that varies from 0 to 1 and it is associated with an activation variable (i.e., $\{0\}$ means no-activate and $\{1\}$ means activate), and each link has an associated real number or weight variable from -1, 1 that reflects the relationship "what-if" between concepts (Papageorgiou and Kontogianni, 2012). With the fitted connection weights, a FCM connection matrix is encoded from each FCM as deeply described in Banini and Bearman (1998).

These maps can be obtained by asking people to define the variables of the system and to identify relationships among these variables using "what if" rules to justify the cause and effect relationship in each connection inferring a semantic weight for each connection (Stylios and Groumpos, 2000, 2004; Papageorgiou and Groumpos, 2005). This information can be facilitated by filling out questionnaires, interviewing people, checking on scaled semantic attributes or drawing arrows of different width on a concept map (Özesmi and Özesmi, 2004).

The construction of a FCM requires the input of human experience and knowledge of the system under consideration. Thus, FCMs integrate the accumulated experience and knowledge concerning the underlying causal relationships among factors, characteristics and components that constitute the system (Papageorgiou and Kontogianni, 2012).

This tool is considered to be a semi-quantitative method because the quantification of concepts and links can be interpreted in relative terms (Kok, 2009). 
The main elements of a FCM are nodes or concepts $\left\{C_{1}, C_{2}, \ldots, C_{n}\right\}$; directed edges $\left\{C_{1} C_{2}\right.$, etc.\} as a set of directed arcs that represent the relationship (positive or negative) between concepts; adjacency matrix $\left(E_{c}=e_{i j}\right)$ as a matrix that contains the values of each relationship (the values belong to the interval from -1 , conversely correlated, and 1 , directly correlated) and state vector $A=\left(a_{1}, a_{2}, \ldots, a_{n}\right)$ where $a_{n}$ is a real number between 0 and 1 , from which the categorical concept status is obtained: 1 activate or 0 no-activate (Kok, 2009; Papageorgiou and Kontogianni, 2012).

\section{Graph theory and FCM}

Cognitive maps are compounds of a large number of variables (one per concept) that have many interconnections and feedback cycles. The direction and numbers of relationships between variables produce three types of concepts: transmitter concepts, receiver concepts and ordinary concepts (Eden et al., 1992; Harary et al., 1965). The type of variables in a map is important, because the map shows the relationships among these variables and facilitates an understanding of its structure (Özesmi and Özesmi, 2004).

Graph theory indices provide a way to characterize FCM structures by means of three indices: outdegree, indegree and the centrality index (Özesmi and Özesmi, 2003, 2004).

\section{FCM development process}

Once the stakeholder and/or expert group interviews were conducted, we obtained an individual FCM from each participant. These individual cognitive maps were augmented and additively superimposed (Kosko, 1987, 1992) to generate the aggregate map (Figure 1). There are a number of different methods to aggregate the individual maps (Van Vliet et al. 2017), each has advantages and disadvantages. In this case, each individual map was combined to generate a group or social map (Mouratiadou and Moran, 2007). For that, each individual matrix was augmented and added, producing a single matrix that represents the FCM. Then, the final aggregated FCM was obtained by normalizing each adjacency matrix element according to the number of experts who supported it, $\mathrm{k}$, and their decisional weight, $p_{i}$ (Eq. 1) (Banini and Bearman, 1998):

$E_{c}=\sum_{i=1}^{k} p_{i} E_{i} / k$

Where $k$ represents the number of experts interviewed; $p_{i}$ is the decisional weight of the expert $i$, where $\sum_{i=1}^{k} p_{i}=1 ; E_{c}$ is the aggregated connection matrix, and $E_{i}$ is the 
connection matrix written by the expert $i$. The use of decisional weight $p_{i}$ for calculating each adjacency matrix element allows a freedom degree for generating new scenarios under different social contexts.

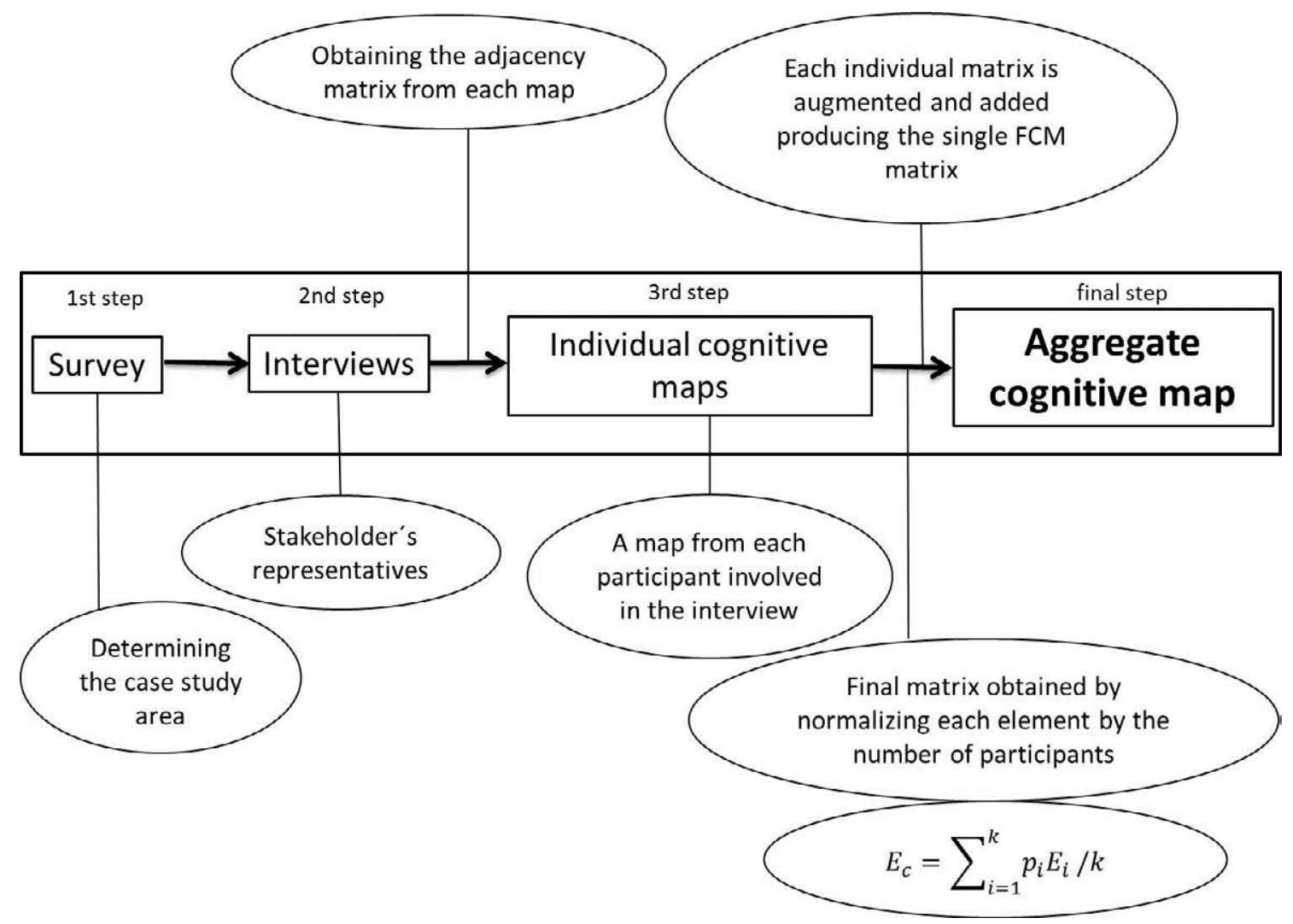

Figure 1. Schematic representation of a step by step FCM generation process. There are 4 main steps, connected in the figure by bold arrows. Bubbles represent the depiction of the process produced in each step and what happens between each step of the process.

The FCM involved an iterative technique, in which each state variable $a_{C i}$ changed its value. Each iteration corresponded to a given interval step, and the value of each item in the current iteration was computed based on the values of the preceding items in the previous simulated iteration. Due to the iterative nature of this process, the system represented by a FCM changes over time as: a) a new steady state at equilibrium, b) an un-converged state and c) a periodic loop of states (Curia and Lavalle, 2011). To facilitate the system convergence in each iteration the values of the state vector were filtered by an activation function. According to Bueno and Salmeron (2009), there are mainly four activation functions that determined the activation level of each concept. Among them we have chosen a sigmoid function (Eq.2), used in other studies that apply FCM (Stylios and Groumpos, 1999).

$f(x)=1 /\left(1+e^{-m\left(x-l_{p}\right)}\right)$ 
Where $m$ is a real positive number (as a general rule, the higher $m$ the safer the convergence), $l_{p}$ is the numerical threshold from dividing each variable into ten activation level (i.e., $p=1 / 10,2 / 10,3 / 10$, and so on), and $x$ is the value of the state variable at a determined iteration. If the variable value is lower than the lowest threshold, $x<l_{p}$, the filter $f(x)$ produces a number close to 0 (implying no activation) while if the variable value is higher, the result will be 1 (implying activation). In scenario simulation this concept division in ten pieces produces a more sensitive response on output variables, and then a more graduated policy can be simulated. This procedure is applied to keep the status variable as a categorical variable which facilitates convergence. In addition, this graduated method offers the possibility of developing easily comparative analysis between scenarios in a complex decisional environment (Bueno and Salmeron, 2009).

\section{Simulation process}

The FCM was used to analyse the system behaviour by running simulations and to determine future possible management scenarios, which can serve to guide environmental managers in the decision-making process regarding the objective system (e.g., the river system). Simulations were made by multiplying the initial state vector $\left(A_{1}\right)$ by the adjacency matrix of the aggregate $\mathrm{FCM}\left(E_{c}\right)$, where $A_{1}$ is a row vector of size $1 \mathrm{xN}$, with $\mathrm{N}$ being the total number of variables (Tan and Özesmi, 2006).

The process of simulation begins when we assign a value of 1 (i.e., activate concept) to each variable. Based on the collective expert/stakeholder knowledge, each activated concept contributed its weight to activate its descendent concepts; then, these concepts are free to interact with others concepts (Papageorgiou and Kontogianni, 2012). In each iteration, the filter function was applied, which produced a new state vector with $\{1\}$ activated concepts and $\{0\}$ no-activate concepts. If a concept has an activation value of 0 , this concept would not contribute at the next iteration, whereas an activation value of 1 would represent the contribution at the next iteration.

The next step was to obtain responses on management scenarios by asking "what-if" questions to determine the state of the system that would be developed under different conditions or if different policy options were implemented (Kosko, 1987).

\section{The case study area}

Esla River is a tributary of Duero River on its right bank, located in the Iberian Peninsula (Fig. 2). It has a basin area of $16026 \mathrm{~km}^{2}$, a length of $287.83 \mathrm{~km}$ and an average of 5066 $\mathrm{hm}^{3}$ annually (CHD, 2015). 


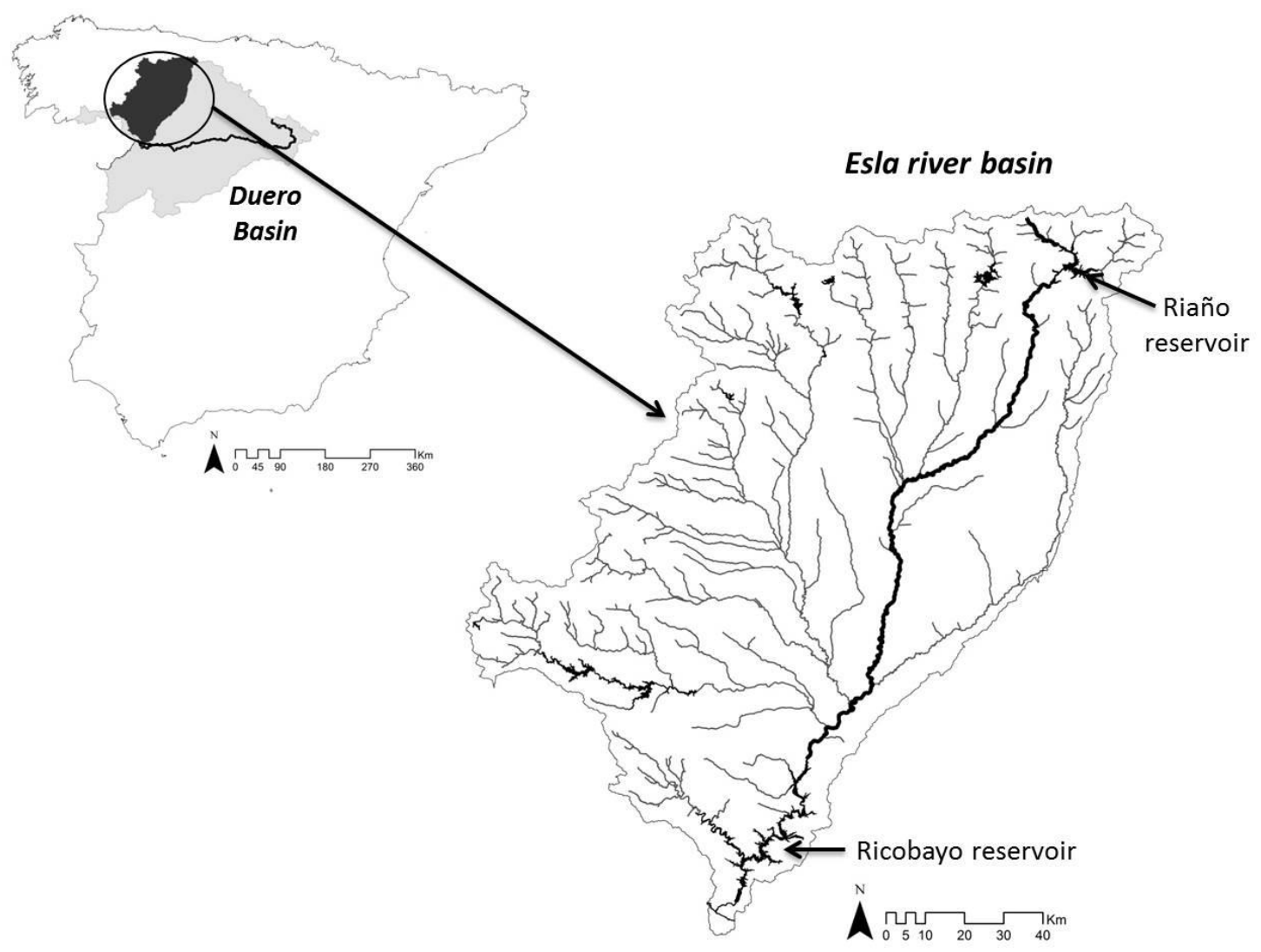

Figure 2. Map of the Esla River Basin located on the northwest part of the Iberian Peninsula.

Two large reservoirs are located along the river. The Riaño is on the river's source, with a maximum capacity of $650 \mathrm{hm}^{3}$ and an area of $817.51 \mathrm{~km}^{2}$ (CHD, 2015). Ricobayo is near the mouth of the Esla River in the Duero River. Ricobayo has a maximum capacity of $1179 \mathrm{hm}^{3}$ and covers an area of $159.52 \mathrm{~km}^{2}$ (CHD, 2015). The presence of these dams conditioned the river's natural flows regime, changing the natural pattern of the river downstream from the dams with an increase of water availability in summer, coinciding with irrigation season. The presence of the Alto de Payuelos, Cea-Carrión, Curueño-Porma and Páramo Bajo channels plays an important role in the Esla River basin regulation (CHD, 2015).

This fluvial system supplies water to a total of 278000 people, including the city of León; to an irrigation area of 97000 ha; to three fish farms; and to the refrigeration system of the Robla thermal power plant. In addition, 19 hydroelectric plants are present, with a combined capacity of $451 \mathrm{MW}$ and an average production of 1115 GWh. A marked increase of irrigation demand is expected (CHD, 2015). 


\section{Application of FCM to Esla River basin.}

An FCM was applied to model the perception of a group of experts in river issues to develop a future Esla River management plan. The FCMs were obtained by seven indepth interviews conducted in group sessions with experts in fluvial ecosystem and water resources who acted as representatives of the river authority, municipalities, farmers and hydroelectric enterprises. We believed that a sample of seven expert interviews was manageable and sufficient to draw conclusions.

At the beginning of the interviews, the participants were given an A4 sheet containing a number of variables that were predefined by the authors to serve as a guideline to the participants as depicted in Table 1. These predefined variables were selected from the REFORM EU project (www.reformrivers.eu), where a conceptual river system scheme was created showing the main interactions between pressures, processes, states, impacts and response variables in European rivers (OECD, 1993; EEA, 2012). This conceptual scheme was made after a deep review process of scientific documents and publications that explicitly reported causal effects between river pressures and biological responses in fluvial systems (García de Jalón et al., 2013; Lorenz 2015).

The participants were also provided with a table that had a rating scale of 10 degrees, numbering from -5 to 5 , by which they could describe any type of connection between the variables (Table 2). The weights of the connections were added when answering the following question: "Do you think that variable $x$ is affected by or affects any other variables?" (Mouratioadou and Moran, 2007).

Table 1. Predefined variables

\begin{tabular}{ll}
\hline \multicolumn{1}{c}{ Variable } & \multicolumn{1}{c}{ Definition } \\
\hline Cross barriers, dams and weirs & $\begin{array}{l}\text { Set of artificial barriers that prevent or } \\
\text { obstruct the natural water flow } \\
\text { Water flow in natural conditions } \\
\text { Natural water flow regime }\end{array}$ \\
Water quality & $\begin{array}{l}\text { Physicochemical status of surface and ground } \\
\text { waters } \\
\text { Sediments dynamics }\end{array}$ \\
Egrosion, transport and sedimentation balance \\
in natural conditions \\
Agricultural and livestock farming in river \\
banks and floodplains (presumably water \\
abstractors) \\
Prban uses, infrastructures
\end{tabular}


Continuity and width of riparian landscapes

Socioeconomic aspects

Riparian vegetation

In-stream communities

Hydroelectric production

River connectivity (longitudinal, lateral and vertical)

Bank conditions
Riparian vegetation in a continuous strip Influence of human activities on river ecosystems

Vegetal species associated with the riparian ecosystem and their quantity and quality

Fish and other animal species populations living in/around the river canal

Alteration of the river ecosystem due to the existence of hydroelectric power plants

Connectivity of riparian ecosystem

Alteration of river banks

To analyse the structure of the map according to the graph theory, important FCM indices such as indegree, outdegree and centrality were calculated in R (Kolaczyk and Csárdi, 2014). The simulation of different management scenarios was also calculated with the Fuzzy Cognitive Mapping \& Modelling software tool (Bachhofer and Wildenberg, 2010) (freely available in www.fcmappers.net). The variables with the highest centrality, indegree and outdegree are depicted in Table 4.

Table 2: Interpretation of the causal relationships between variables

\begin{tabular}{ccc}
\hline $\begin{array}{c}\text { Strength connection by } \\
\text { interviewer }\end{array}$ & $\begin{array}{c}\text { Sign and strength of } \\
\text { relationship } \\
\text { (linguistic weight) }\end{array}$ & Interpreted crisp weight \\
\hline-5 & Negatively very strong & -1 \\
-4 & Negatively strong & -0.8 \\
-3 & Negatively medium & -0.6 \\
-2 & Negatively weak & -0.4 \\
-1 & Negatively very weak & -0.2 \\
1 & Positively very weak & 0.2 \\
2 & Positively weak & 0.4 \\
3 & Positively medium & 0.6 \\
4 & Positively strong & 0.8 \\
5 & Positively very strong & 1 \\
\hline
\end{tabular}




\section{Results}

\section{FCM outcome}

The number of variables in the seven individual FCMs was 13 , while $46.57 \pm 26.42$ connections $( \pm S D)$, on average, were observed into them. So, a total of 13 variables with 114 connections were observed in the aggregated FCM (Table 3), which are shown in Figure 3, painted with the software Pajek (Batagelj and Mrvar, 1998).

Table 4: Comparison of the values between individual maps and collective FCM

\begin{tabular}{lcc}
\hline \multicolumn{1}{c}{ Index } & Individual FCMs & Aggregated FCM \\
\hline Number of maps & 7 & 1 \\
Variables & 13 & 13 \\
Number of connections & $46.57 \pm 26.42$ & 114 \\
Connections/variables & 1.58 & 8.77 \\
Density & 0.124 & 0.67 \\
\hline
\end{tabular}

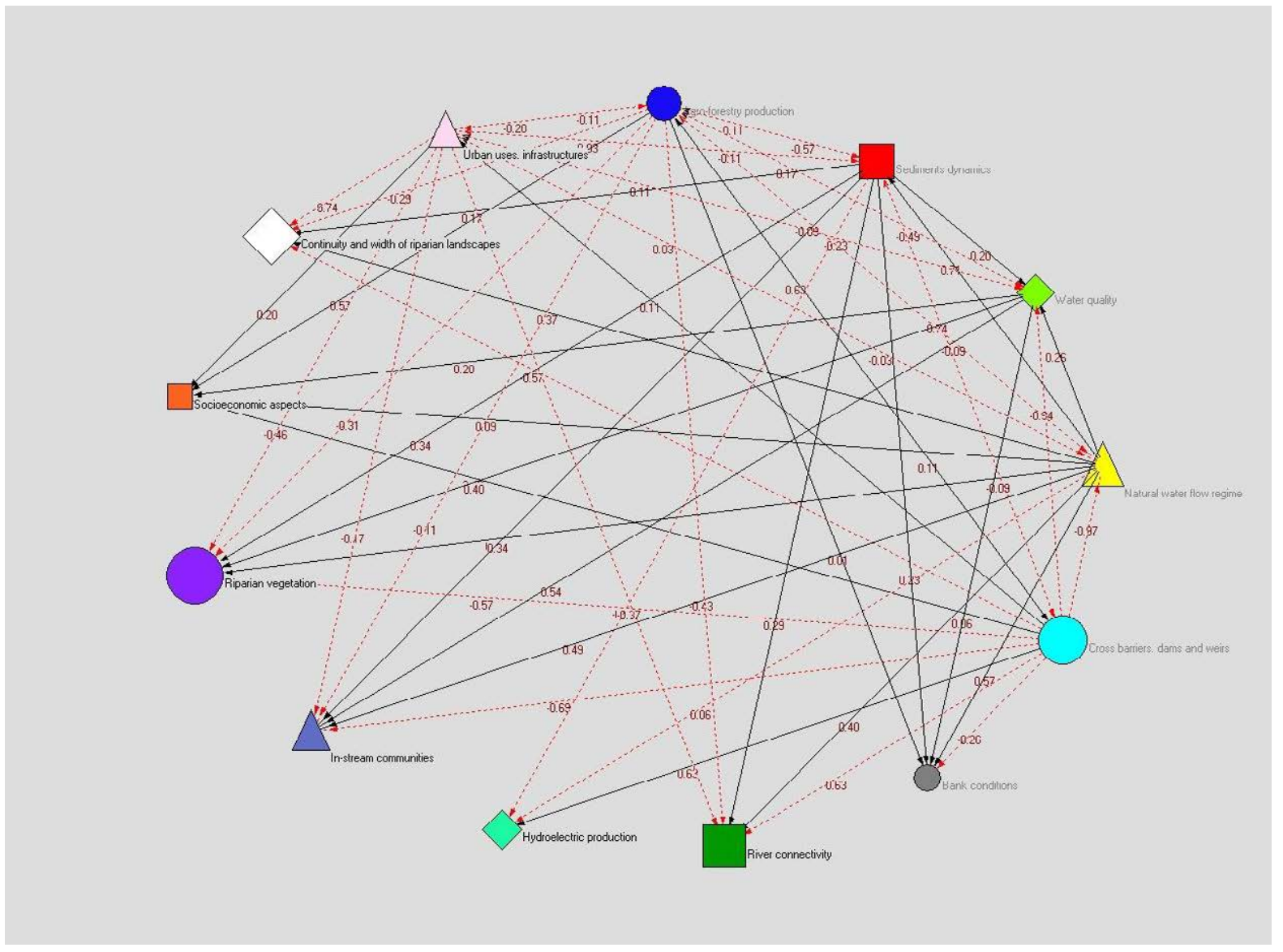

Figure 3. Aggregated FCM of the Esla River.

As seen in Figure 3, arrows mean the causal-effect relationships and nodes symbolise concepts. The continuous lines represent positive relationships while dotted lines 
represent a negative relationship. The most influential or central variable was "Cross barriers, dams and weirs" as many arrows come in and come out from this node. The most affected variables (i.e., receivers) by others are (in order) "Riparian vegetation", "River connectivity", "Sediment dynamics", "Continuity and width of riparian landscapes", "In-stream communities", "Water quality", "Bank conditions" and "Socioeconomic aspects".

The most central variable was "Cross barriers, dams and weirs." This variable had a strong effect on the other variables (outdegree of 6.54), and they were affected by an indegree of 0.4 . The variables were ordered according to their centrality, as shown in Figure 4 and Table 4.

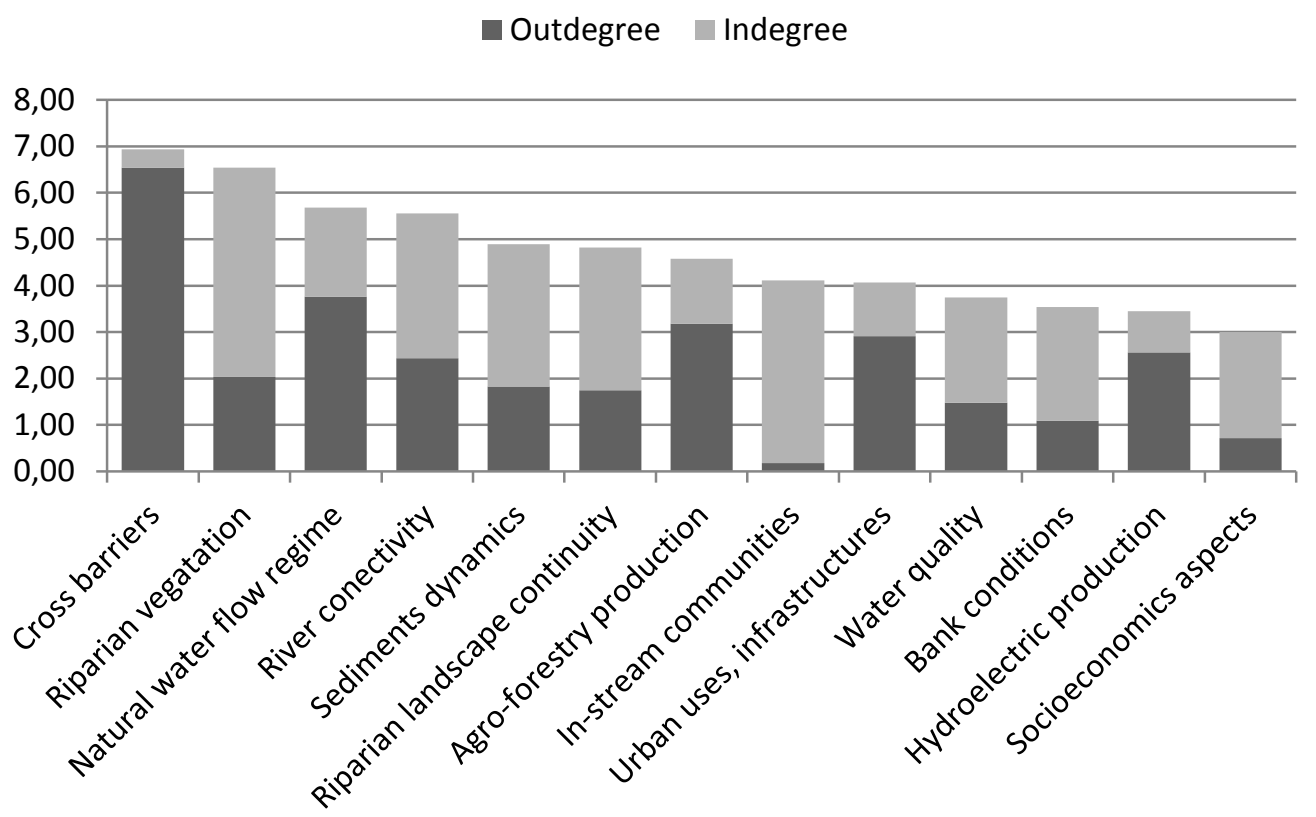

Figure 4. Representation of the importance of the variables in the aggregated FCM according to their centrality, which is the sum of the indegree and outdegree of a variable, and demonstrates the importance of the variable.

The variables that greatly affected other variables (outdegree > indegree) (i.e., transmitters or drivers) were "Cross barriers, dams and weirs", "Natural water flow regime", "Agro-forestry production", "Urban uses" and "Hydroelectric production", whereas the opposite situation was for "Riparian vegetation", "River connectivity", "Sediment dynamics", "Continuity and width of riparian landscapes", "In-stream communities", "Water quality", "Bank conditions" and "Socio-economic aspects" (Table 4). 
Table 4: Variables with the highest centrality, indegree and outdegree.

\begin{tabular}{|c|c|c|}
\hline $\begin{array}{l}\text { Centrality } \\
\text { (Influential) }\end{array}$ & $\begin{array}{c}\text { Indegree } \\
\text { (Receiver or state) }\end{array}$ & $\begin{array}{c}\text { Outdegree } \\
\text { (Transmitter or driver) }\end{array}$ \\
\hline $\begin{array}{l}\text { Cross barriers, dams and } \\
\text { weirs }\end{array}$ & Riparian vegetation & $\begin{array}{l}\text { Cross barriers, dams and } \\
\text { weirs }\end{array}$ \\
\hline Riparian vegetation & In-stream communities & Natural water flow regime \\
\hline Natural water flow regime & River connectivity & Agro-forestry production \\
\hline
\end{tabular}

\section{Scenario simulations}

First, the steady state of the Esla River system was obtained before considering any fluvial management action. The steady state vector characterized the system according to the panel of experts', actors' and stakeholders' knowledge. If a concept was reinforced by a policy, the state vector would change, and the effects would be measured as a difference of the value of the concepts. To determine the steady state, we ran a FCM process starting with an initial state vector $A 0$, with all variables set to 1 (Figure 5), and after convergence an equilibrium or steady state vector was obtained. Then we ran a battery of simulations with different activation levels (i.e., from 0 to 1 by 0.1 ) for some specific concepts to generate different restoration scenarios (Figure 6).

Expectedly, "Cross barriers" was the most central variable, because this concept was an artificial element that altered further natural river conditions and affected many of the socio-economic variables. Next, the most central variables, such as "Riparian vegetation" and "Natural water flow regime", were the natural variables that were currently affected by anthropic activities in the Esla River Basin. 


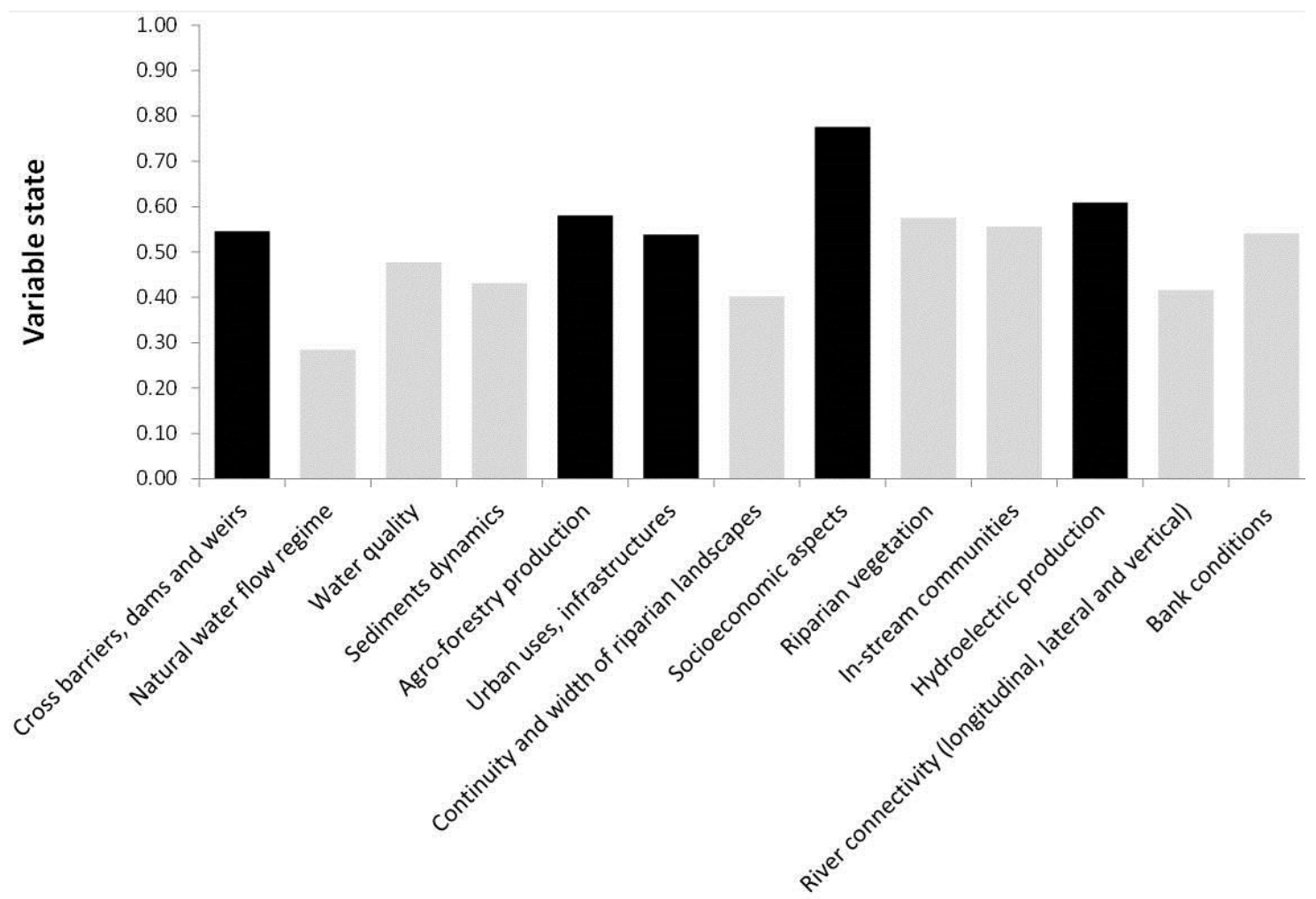

Figure 5: Simulation of the steady state conditions of the variables obtained from the aggregate FCM. Environmental variables are coloured in grey and the socioeconomic variables are coloured in black.

As Figure 5 shows, socioeconomic variables had higher initial values than most of the environmental variables, because the Esla River, like most Mediterranean rivers, is a system that is heavily degraded by anthropogenic activities (EEA, 2012). Therefore, socioeconomic variables had a very high initial value, despite not being the most central variables in our knowledge map. Otherwise, the "Natural water flow regime" showed a low value in our steady state system, due to the strong influence that other variables with high outdegree values, such as "Cross barriers" or "Agroforestry production", had on the system.

The importance of the generation of simulation scenarios was to measure the change experienced by the variables from their steady state values. Therefore, we fairly accurately measured and quantified the effects of different actions applied to the management of the Esla River. In our study, we aimed to determine the results of simulating variables with high outdegree values regarding variables with large indegree values, because we considered the importance of regulating the effects of the strong variables and how most sensitive variables reacted when changes were made. 


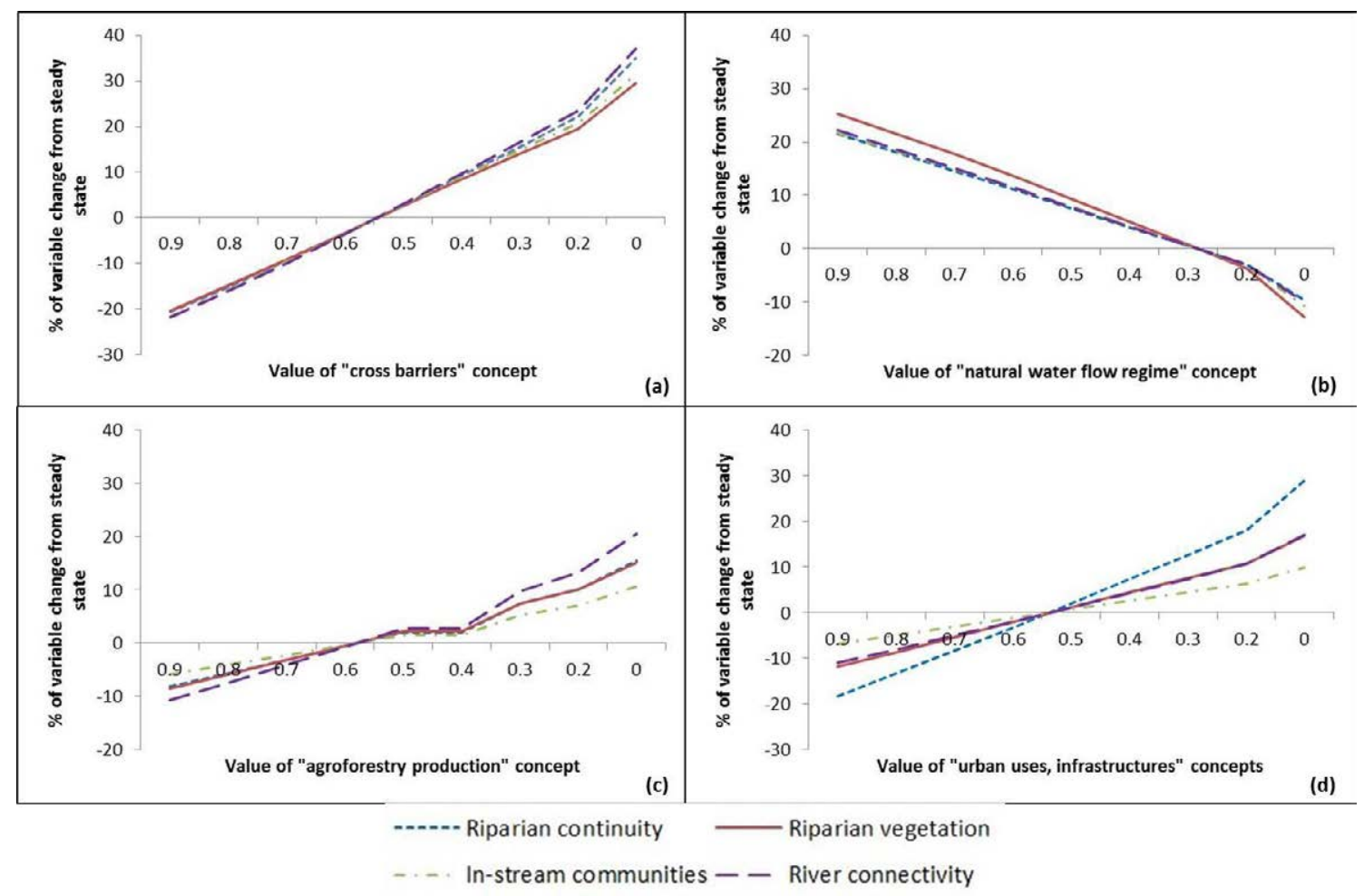

Figure 6. Influence of concepts with a high outdegree (i.e., transmitters or drivers) on concepts with a high indegree (i.e., receivers or state). We simulated the values of the concepts with high outdegree values on the variables with high indegree values to determine the percentage of change from steady state conditions under different management situations. Situation 1 (a): Simulation of the "Cross barriers" concept in which a decrease determines a continuous increment in the selected variables. Situation 2 (b): The decrease in the value of the variable "Natural water flow regime" caused a progressive reduction in the value of the selected variables. Situation 3 (c): A decline in the variable "Agroforestry production" produces a general increment with a flat tendency when the value of the simulation was between 0.6 and 0.4. Situation 4 (d): An increasing trend in the values of the analysed variables was observed when performing a downward simulation of the variable "Urban uses, infrastructures".

Once the effects of simulating the main high outdegree variables were determined, different management scenarios were developed based on the simulation of one of the system variables or several variables together. These scenarios included: 1) the increase in the presence of dams due to the requirements of agricultural uses and 2) the increase of river connectivity, especially longitudinal connectivity. The objective was to measure the degree to which the variables changed from their steady state values. A negative value indicated a reduction in the variable state compared with the initial conditions, while a positive value reflected an increase in the variable state (Tan and Özesmi, 2006).

Scenario 1: increment the presence of transversal barriers 
This scenario simulated the effects of increasing the number of cross barriers (dams and weirs) in the river. We expected the decrease of natural water flow, which meant that there was an alteration in the sediment balance. The longitudinal connectivity of the river also decreased due to the discontinuity generated by the presence of new obstacles. On the contrary, we expected the agro-forestry production, infrastructures, hydroelectric production and socioeconomic aspects to increase.

\section{Scenario 2: increment of river connectivity}

This scenario simulated the effects of increasing the river connectivity of the Esla River. We expected the decrease in the presence of artificial barriers and, therefore, an increase in natural water flow regime, sediments dynamics, riparian vegetation, riparian landscape continuity, in-stream communities and bank conditions.

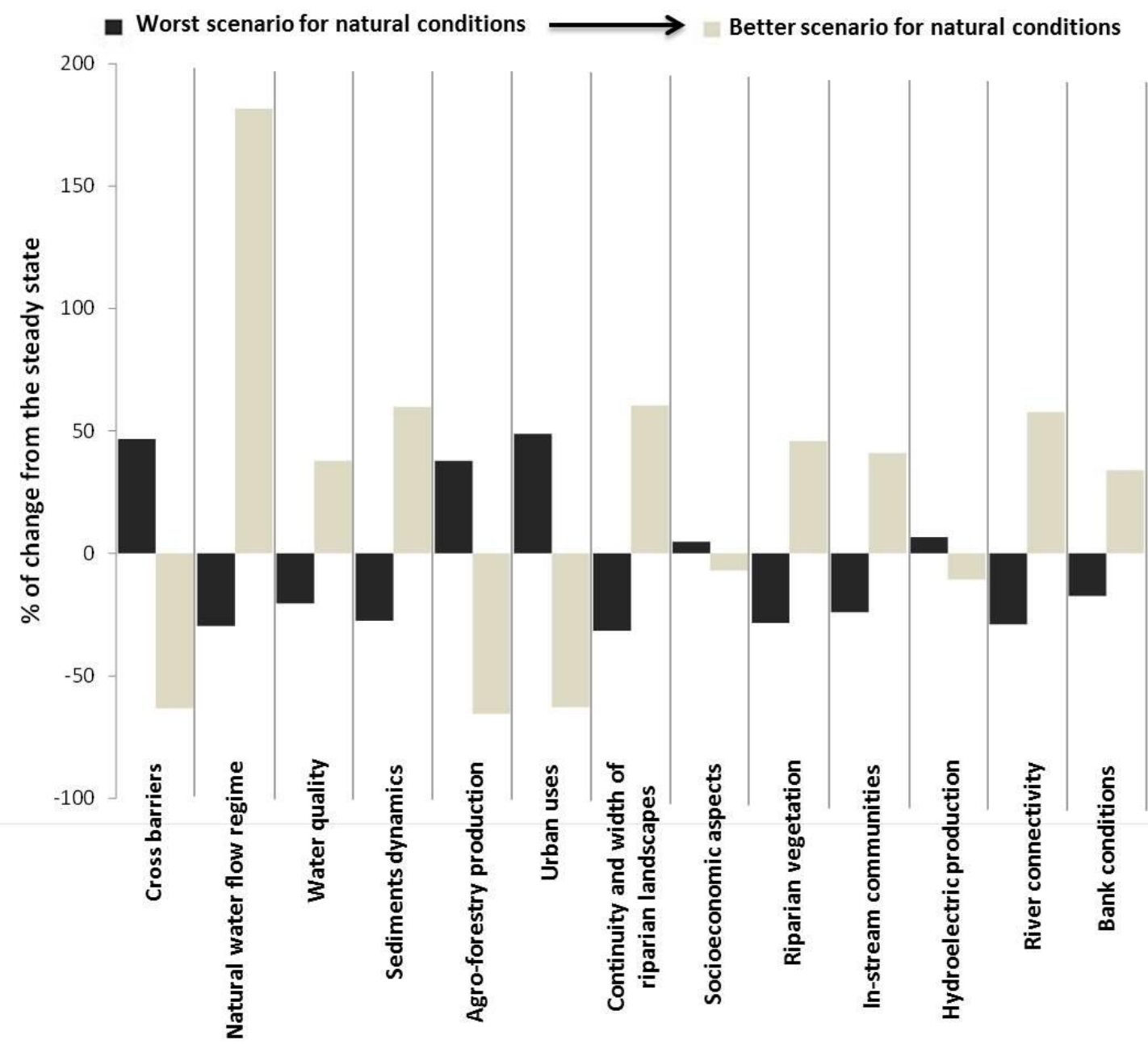

Figure 7. Effects of simulating several concepts in our aggregated FCM. We simulated a decrease in the transmitter concepts "Cross barriers" (1), "Agroforestry production" (5) and "Urban uses, infrastructures" (6), while there was an increase in the "Natural water flow regime" (2), and we obtained the relative effects on the other variables: "Water quality"(3), 
"Sediments dynamics" (4), "Continuity and width of riparian landscapes" (7), "Socioeconomic aspects" (8), "Riparian vegetation" (9), "In-stream communities" (10), "Hydroelectric production" (11), "River connectivity" (12), and "Bank conditions" (13). The results depicted the percentage of change from the steady state in two different simulations: from a worst scenario for natural conditions (dark coloured bars) to the best scenario for natural conditions (light coloured bars) and the tendency among both scenarios.

\section{Discussion}

\section{Characteristics of the variables}

The variables of our aggregated FCM were all ordinary, meaning that causal relationships existed among these variables. However, certain variables had high values in their outdegrees, suggesting that specific variables strongly influenced the system and could be considered to be drivers ("agroforestry production", "urban uses", "cross barriers" and others) or pressures (disturbance of "natural flow regime") according to the DPSIR classification (i.e., Drivers, Pressure, State, Impact, Response) (OECD, 1993; EEA, 2012). The drivers, as variables that will be less affected by changes in the system, are ideal candidates to manipulate the system (van Vliet et al. 2017). This driver concept may produce environmental effects on the structure and functioning of the river (García de Jalón et al., 2013), which was mostly reflected on the high indegree variables considered to be state variables (i.e., "river connectivity", "continuity and width of riparian corridor", "riparian vegetation" and "in-stream communities") that were related to abiotic or biotic ecosystem conditions (García de Jalón et al., 2013). In summary, the values of the variable's indegree and outdegree were important in determining the roles of the variable in the ecosystem. Moreover the most important variables were those with high centrality values, because they controlled the dynamics of the system. This concept classification (i.e., driver vs state) highlighted the FCM robustness for capturing the core concepts of the fluvial ecosystem by only using qualitative information (Tan and Özesmi, 2006). In addition, the procedure for building the aggregate cognitive map from a different set of points of view provided a high level of representativeness for the FCM results.

\section{Aggregation process, steady vector and general issues}

This study explored the use of the FCM as a tool for simulating fluvial ecosystem responses and forecasting concept trends. Some drawbacks can be found during the aggregation process where the individual maps are combined into a general one. The existence of new methodologies recently published for map aggregation can be 
combined with previous simpler aggregation methodologies: however there is no consensus on how to best construct the aggregated FCM (van Vliet et al. 2017). Despite, the aggregate FCM was used in this research to reach the steady state vector by activating start concepts and then obtaining responses by solving a system of filtered linear equations. Adjacent matrix coefficients were estimated as an average of the individual expert's values, and standard error can be also estimated for each coefficient. This provided an estimate interval and a significance level to evaluate the FCM explicative power (Shmueli, 2010; Shmueli and Koppius, 2011). In addition, keeping adjacency matrix for each representative expert allows making weighted averages based on different social composition. For instance, a change toward a more "ecologist" concerned society can be model by an increment in the weight of ecologist representative, conversely, a more "productivist" society shall be model by higher loading for farmer and landowners.

In the Esla River FCM, the steady state vector showed an ecosystem that was greatly influenced by human activity, in which the economic and social variables presented high network influence, even though their centrality indices were relatively low. Meanwhile, the essential elements for the proper functioning of this ecosystem, as a "natural flow regime", showed very low values that were affected by anthropogenic variables.

\section{Simulation of management scenarios}

The aggregate cognitive map can be considered an a priori model of the analysed ecosystem. When an expert made their FCM, it is supposed to apply their full knowledge along with the accessible information. The methodology was based on the comparison of different steady state vectors obtained from different activation vectors composed of a different set of activated variables, by different action levels of activate levels or both. The interpretation of the simulated scenarios in the present study was that the results should be interpreted in a qualitative, rather than a quantitative, manner (Tan and Özesmi 2006). Despite this, FCMs are a promising structuring tool in the scenario development (van Vliet et al. 2012).

\section{Scenario 1: increment the presence of transversal barriers}

This scenario simulated an increment in the placement of new artificial barriers in the Esla River (Figure 7). The highest indegree variables were greatly affected by the increment in the value of this variable, whose outdegree was the highest of the entire system. The width and continuity of the riparian corridor would be affected, because 
the river regulation involves fundamental changes in the flow and sediment transfer, which were the main factors in fluvial morphodynamic changes (Church, 1995). The trend of an increase in agricultural land in the study area corresponded to the need to build more water storage structures that would alter the ecosystem downstream of its location (Ward and Stanford, 1983, 1995; Petts and Gurnell, 2005, 2013; Vörösmarty et al., 1997). As shown in Figure 6.a, the presence of riparian vegetation would be reduced downstream of the dams (Nilsson et al, 1991; Anderson et al, 2000; Merritt et al, 2010, Merritt and Wohl, 2002, 2006). Figure 6.a. also shows that in-stream communities were not immune to the further fragmentation of the river. A strong impact on species migration and diversity was due to the effect of artificial barriers (Kingsford 2000 a, b; Cote et al 2009; Jager et al 2001). Clearly, the hydrological connectivity would be greatly altered by the existence of dams (Ward and Stanford, 1983, 1995, 2006; Segurado et al 2013, 2014). Pringle (2003) argued that "hydrologic connectivity is essential to the ecological integrity of the landscape, and reduction or enhancement of this property by humans can have major negative environmental effects".

\section{Scenario 2: increment of river connectivity}

This scenario simulated a situation in which an increase of river connectivity was achieved due to the intervention of other variables ("Cross barriers", "Agroforestry production", "Urban uses, infrastructures", etc.), which caused a hindrance to the natural connectivity of the river (Figure 7). According to the idea of the multiple dimensions of fluvial connectivity (Ward 1989), the measurements made in this simulation were aimed at diminishing the importance of the variables that generated a disturbance in one or more of the river connectivity dimensions. Variables such us "agro-forestry production" and "urban uses" would be reduced from their initial values due to an increase in the interactions of the river channel with the adjacent riparian system and the floodplain, improving the exchanges of nutrients and organic matter (Ward, 1989).

Special efforts to improve the longitudinal dimension of connectivity should be considered, as it determines several vital ecological processes (Ward 1989; Tockner et al., 1998; Lucas and Baras 2001). The reduction of the disconnection generated by artificial barriers lead to a progressive increase in the water flow regime, which could be the most important measure to recover the riverine ecology, and it needs to be implemented first in a fluvial restoration process (Lorenz et al, 2015). The variable "instream communities" increased its value parallel to an increment in the connectivity 
value due to the longitudinal connectivity restoration having positive impacts on fish species, especially in migratory species (Segurado et al, 2014).

For these reasons, all of the approaches that were oriented to enhance the unions between habitat patches (in this case, river segments separated by artificial barriers) should be applied in conservation planning (Erös et al., 2011).

\section{Conclusion}

The present river management will produce a future response on the river ecosystem which should be forecasted. The use of FCMs to determine the behaviour of Esla River and possible future management scenarios was useful in building a model based on the available knowledge of how a complex system was perceived, because more detailed information may not be available. This methodology dealt with the connections between the ecological and social concepts of an ecosystem. FCMs are subject to limitations due to their semi-quantitative approach. Nevertheless, they were proven to be suitable for organizing complex ecosystem models, in which concepts and the causal relationships between them could be determined. The analysis of how variables with high outdegree values affected variables with high indegree values was valuable for quantifying the effects of the impact over the most sensitive variables and for determining the behaviour of the system. The simulations suggested that to develop an effective fluvial management plan according to the experts involved in the process, a reduction in the effects of the artificial barriers that leads to an increase of the naturalization of the river system is necessary.

Stakeholder participation is the primary component of the FCM methodology. In this case, the reviews of seven experts regarding river issues provided a clear description of how the river ecosystem worked together. Expanding the use of this methodology to other stakeholders, such as local residents, consumer associations or ecologists, for further research and studies will be essential. However, more research is needed on the process of aggregating individual maps into a single map to prevent that the perceived knowledge on their individual map by each stakeholder are undervalued on the final map.

Therefore, we determined that FCMs were a good tool for decision making and could be a suitable methodology for generating simulations of future policy scenarios aimed to develop realistic fluvial restoration works and better conservation strategies. 


\section{Acknowledgements}

This research was partially supported by the European Union $7^{\text {th }}$ Framework Project REFORM under contract no. 282656. Two anonymous reviewers are thanked for their helpful comments and insights.

\section{References}

Andersson E, Nilsson C, Johansson ME. 2000. Plant dispersal in boreal rivers and its relation to the diversity of riparian flora. J. Biogeogr. 27, 1095-1106.

Bachhofer M, Wildenberg M. 2010. FCMappers (http://www.fcmappers.net).

Banini GA, Bearman RA. 1998. Application of fuzzy cognitive maps to factors affecting slurry rheology. Int. J. Miner. Process. 52, 233-244.

Batagelj V, Mrvar A. 1998. Pajek - Program for Large Network Analysis. Connections 21, 47-57.

Bueno S, Salmeron JL. 2009. Benchmarking main activation functions in fuzzy cognitive maps. Expert Systems with Applications, 36(3), 5221-5229.

CHD. 2015. Confederación Hidrográfica del Duero. http://www.chduero.es. Last access on 3-May-2015.

Church M. 1995. Geomorphic response to river flow regulation: Case studies and timescales. Regulated Rivers: Research \& Management 11, 3-22.

Cote D, Kehler DG, Bourne C, Wiersma YF. 2009. A new measure of longitudinal connectivity for stream networks. Landsc. Ecol. 24, 101-113.

Curia L, Lavalle A. 2011. Decision strategies in dynamic systems using fuzzy cognitive maps. Application to a socio - economic example. Journal of Information System and Technology Management 8 (3), 663-680.

Eden C, Ackerman F, Cropper S. 1992. The analysis of cause maps. J. Manage. Stud. 29, 309-323.

Elosegi A, Diez JR, Mutz M. 2010. Effects of hydromorphological integrity on biodiversity and functioning of river ecosystems. Hydrobiologia 657, 199-215.

Erös T, Schmera D, Schick RS. 2011. Network thinking in riverscape conservation-a graph-based approach. Biological Conservation, 144(1), 184-192.

Eshuis J, Stuiver M. 2005. Learning in context through conflict and alignment: farmers and scientists in search of sustainable agriculture. Agric. Human Values 22(2), 137-148.

European Environmental Agency. 2012. European waters - assessment of status and pressures. EEA Report No 8/2012 
García de Jalón D, Alonso C, González del Tango M, Martínez V, Gurnell A, Lorenz S, Wolter C, Rinaldi M, Belletti B, Mosselman E, Hendriks D, Geerling G. 2013. Review on pressure effects on hydromorphological variables and ecologically relevant processes. REFORM (7th FP No.282656), Deliverable D1.2. Effects of pressures on hydromorphology, http://www.reformrivers.eu/deliverables/d1-2

Giordano R, Passarella G, Uricchio VF, Vurro M. 2005. Fuzzy cognitive maps for issue identification in a water resources conflict resolution system. Phys. Chem. Earth 30, 463-469.

Harary, F, Norman RZ, Cartwright D. 1965. Structural Models: An Introduction to the Theory of Directed Graphs. John Wiley \& Sons, New York.

Hommes S, Vinke de Kruijf J, Otter HS, Bouma G. 2009. Knowledge and Perceptions in Participatory Policy Processes: Lessons from the Delta-Region in the Netherlands. Water Resour. Manag. 23, 1641-1663.

Jager HI, Chandler JA, Lepla KB, Van Winkle W. 2001. A theoretical study of river fragmentation by dams and its effects on white sturgeon populations. Environ. Biol. Fishes 60, 347-361.

Johnson N, Ravnborg HM, Werstermann O, Probst K. 2001. User participation in watershed management and research. Water Policy 3, 507-520.

Kauffman JB, Beschta RL, Otting N, Lytjen D. 1997. An ecological perspective of riparian and stream restoration in the Western United States. Fisheries 22(5), 12-24.

Kingsford RT. 2000. Ecological impacts of dams, water diversions and river management on floodplain wetlands in Australia. Austral Ecology 25, 109-127.

Kok K. 2009. The potential of Fuzzy Cognitive Maps for semi-quantitative scenario development, with an example from Brazil. Global Environmental Change 19, 122-133.

Kolaczyk ED, Csárdi G. 2014. Statistical analysis of network data with R (Vol. 65). Springer.

Kosko B. 1986. Fuzzy cognitive maps. Int. J. Man-Machine Stud. 1, 65-75.

Kosko B. 1987. Adaptive inference in fuzzy knowledge networks. In: Proceedings of the First IEEE International Conference on Neural Networks (ICNN-86), San Diego, CA, pp. 261-268.

Lorenz S, Martínez-Fernández V, Alonso C, Mosselman E, García de Jalón D, González del Tánago M, Belletti B, Hendriks D, Wolter C. 2015. Fuzzy cognitive mapping for predicting hydromorphological responses to multiple pressures in rivers. Journal of Applied Ecology 53(2), 559-566.

Lucas MC, Baras E, Thom TJ, Duncan A, Slavík O. 2001. Migration of freshwater fishes (Vol. 47). Oxford: Blackwell Science. 
Malek Z. 2017. Fuzzy-Logic Cognitive Mapping: Introduction and Overview of the Method. In: Environmental Modeling with Stakeholders, Theory, Methods and Applications. S. Gray, M. Paolisso, R. Jordan, S. Gray (Eds.) (chapter 7, pp127143)

Merritt DM, Wohl EE. 2002. Processes governing hydrochory along rivers: hydraulics, hydrology, and dispersal phenology. Ecol. Appl. 12, 1071-1087.

Merritt DM, Wohl EE. 2006. Plant dispersal along rivers fragmented by dams. River Res. Appl. 22, 1-26.

Merritt DM, Nilsson C, Jansson R. 2010. Consequences of propagule dispersal and river fragmentation for riparian plant community diversity and turnover. Ecol. Monogr. 80, 609-626.

Millennium Ecosystem Assessment. 2005. Ecosystems and human well-being: synthesis. Island Press, Washington, DC.

Mouratiadou I, Moran D. 2007. Mapping public participation in the Water Framework Directive: A case study of the Pinios River Basin, Greece. Ecol. Econ. 62, 66-76.

Nilsson C, Ekblad A, Gardfjell M, Carlberg B. 1991. Long-term effects of river regulation on river margin vegetation. J. Appl. Ecol. 28, 963-987.

OECD. 1993. OECD Core Set of Indicators for Environmental Performance Reviews. A synthesis report by the Group on the State of the Environment. Environment Monographs, 83. Paris

Özesmi U, Özesmi SL. 2003. A participatory approach to ecosystem conservation: Fuzzy cognitive maps and stakeholder analysis in Uluabat Lake, Turkey. Environ. Manage. 31(4), 518-531.

Özesmi U, Özesmi SL. 2004. Ecological Models based on People's Knowledge: A MultiStep Fuzzy Cognitive Mapping Approach. Ecol. Model. 176, 43-64.

Paolisso M, Trombley J. 2017. Cognitive, Material and Technological Considerations in Participatory Environmental Modeling. In: Environmental Modeling with Stakeholders, Theory, Methods and Applications. S. Gray, M. Paolisso, R. Jordan, S. Gray (Eds.) (chapter 1, pp3-23)

Papageorgiou El, Groumpos PP. 2005. A new hybrid method using evolutionary algorithms to train Fuzzy Cognitive Maps. Appl. Soft. Comput. 5, 409-431.

Papageorgiou El, Markinos A, Gemtos T. 2009. Application of fuzzy cognitive maps for cotton yield management in precision farming. Expert Syst. Appl. 36 (10), 12399-12413.

Papageorgiou El, Kontogianni A. 2012. Using Fuzzy Cognitive Mapping in Environmental Decision Making and Management: A Methodological Primer and an Application, International Perspectives on Global Environmental Change. Dr. Stephen Young (Ed.), InTech 
Park KS, Kim SH. 1995. Fuzzy Cognitive Maps considering time relationships. Int. J. Hum.-Comput. Stud. 42, 157-168.

Petts GE, Gurnell AM. 2005. Dams and geomorphology: research progress and future directions. Geomorphology 71, 27-47.

Petts GE, Gurnell AM. 2013. Hydrogeomorphic effects of reservoirs, dams and diversions. In: Shroder, J. (Editor in chief), James, L.A., Harden, C.P., Clague, J.J. (Eds.), Treatise on Geomorphology. Academic Press, San Diego, CA, vol. 13, Geomorphology of Human Disturbances, Climate Change, and Natural Hazards, 96-114.

Pringle C. 2003. What is hydrologic connectivity and why is it ecologically important? Hydrol. Process. 17, 2685-2689.

Rinaudo JD, Garin P. 2005. The benefits of combining lay and expert input for watermanagement planning at the watershed level. Water Policy 7(3), 279-294

Segurado P, Branco P, Ferreira MT. 2013. Prioritizing restoration of structural connectivity in rivers: a graph based approach. Landscape Ecol 28, 1231-1238

Segurado P, Branco P, Avelar AP, Ferreira MT. 2014. Historical changes in the functional connectivity of river based on spatial networks analysis and the past occurrences of diadromous species in Portugal. Aquatic Sciences.

Shmueli G. 2010. To explain or to predict? Statistical science, 289-310.

Shmueli G, Koppius OR. 2011. Predictive Analytics in Information Systems Research. MIS Quarterly, Vol. 35, No. 3, pp. 553-572.

Stylios CD, Groumpos PP. 1999. Mathematical formulation of fuzzy cognitive maps. In Proceedings of the 7th Mediterranean Conference on Control and Automation (pp. 2251-2261).

Stylios CD, Groumpos PP. 2000. Fuzzy cognitive maps in modeling supervisory control systems. J. Intell. Fuzzy Syst. 8, 83-98.

Stylios, CD, Groumpos PP. 2004. Modelling complex systems using Fuzzy Cognitive Maps. IEEE Trans. Syst. Man Cybern. Part A 34 (1), 155-162.

Tan CO, Özesmi U. 2006. A generic shallow lake ecosystem model based on collective expert knowledge. Hydrobiologia 563, 125-142.

Tockner K, Schiemer F, Ward JV. 1998. Conservation by restoration: the management concept for a river-floodplain system on the Danube River in Austria. Aquat Conserv 8, 71-86.

van Vliet M, Kok K, Veldkamp A, Sarkki S. 2012. Structure in creativity: An exploratory study to analyse the effects of structuring tools on scenario workshop results. Futures, 44(8), 746-760. 
van Vliet M, Flörke M, Varela-Ortega C, Çakmak EH, Khadra R, Esteve P, D'Agostino D, Dudu H, Bärlund I, Kok K. 2017. FCMs as a common base for linking participatory products and models. In: Environmental Modeling with Stakeholders, Theory, Methods and Applications. S. Gray, M. Paolisso, R. Jordan, S. Gray (Eds.) (chapter 8, pp145-170)

Vörösmarty CJ, Meybeck M, Fekete B, Sharma K. 1997. The potential impact of neocastorization on sediment transport by the global network of rivers. Proc. Rabat Symp. On Human impact on erosion and sedimentation, IAHS Public 24, 261273.

Ward JV, Stanford JA. 1983. The serial discontinuity concept of lotic ecosystems. In Fontaine, T.D. and Bartell, S.M. (Eds.) Dynamics of lotic ecosystems, Ann Arbor Science, pp. 29-42.

Ward JV. 1989. The four-dimensional nature of lotic ecosystems. Journal of the North American Benthological Society, 2-8.

Ward JV, Stanford JA. 1995. The serial discontinuity concept: extending the model to floodplain rivers. Regulated Rivers: Research and Management 10, 159-168.

Ward JV, Stanford JA. 2006. Ecological connectivity in alluvial river ecosystems and its disruption by flow regulation. Regulated Rivers: Research and Management 11, 105-119 
